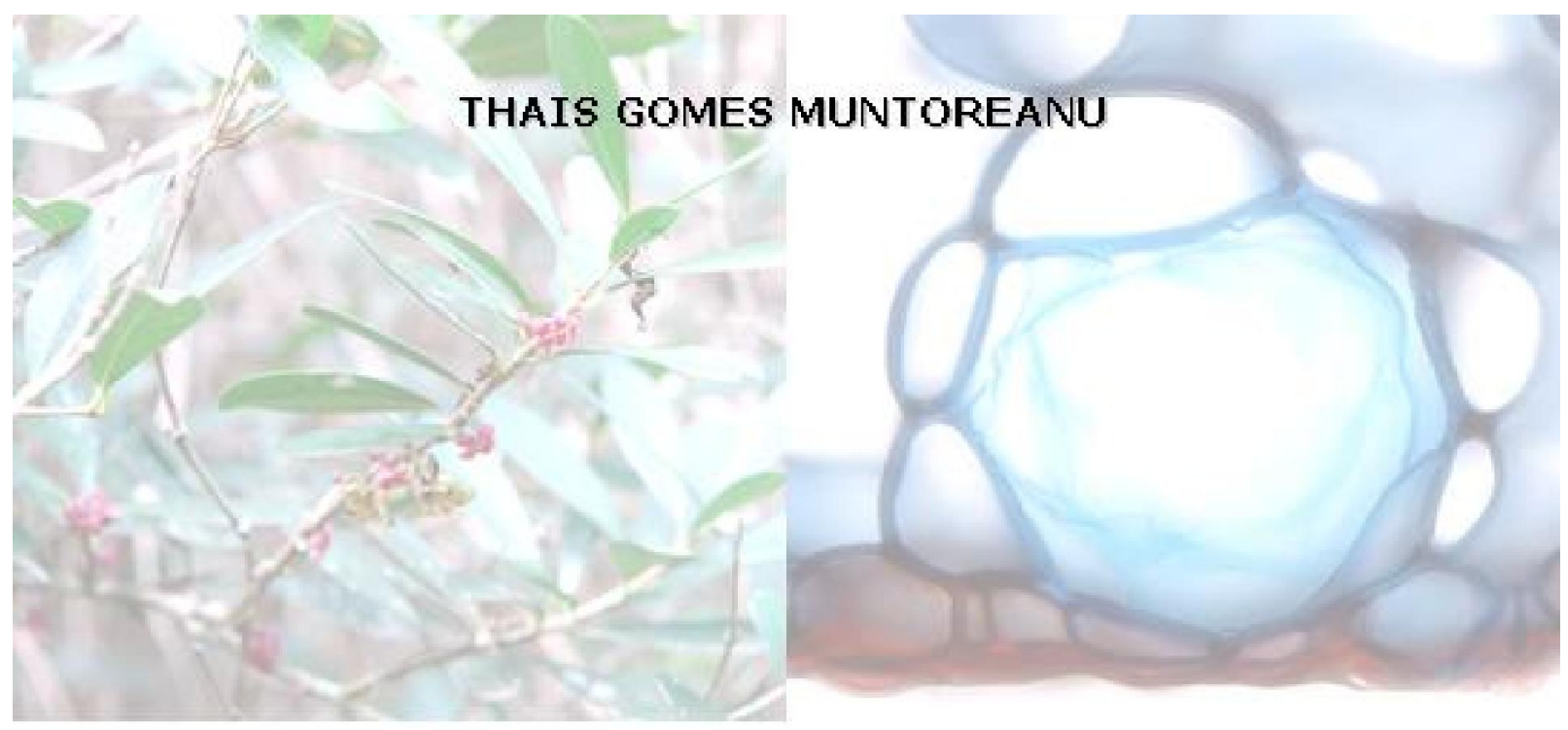

DESCRIÇÃO E MAPEAMENTO DE CARACTERES MORFO-



ANATOMICOS FOLIARES EM PIIOCarpüS VAHL

(RUTACEAE) E GÊNEROS RELACIONADOS-

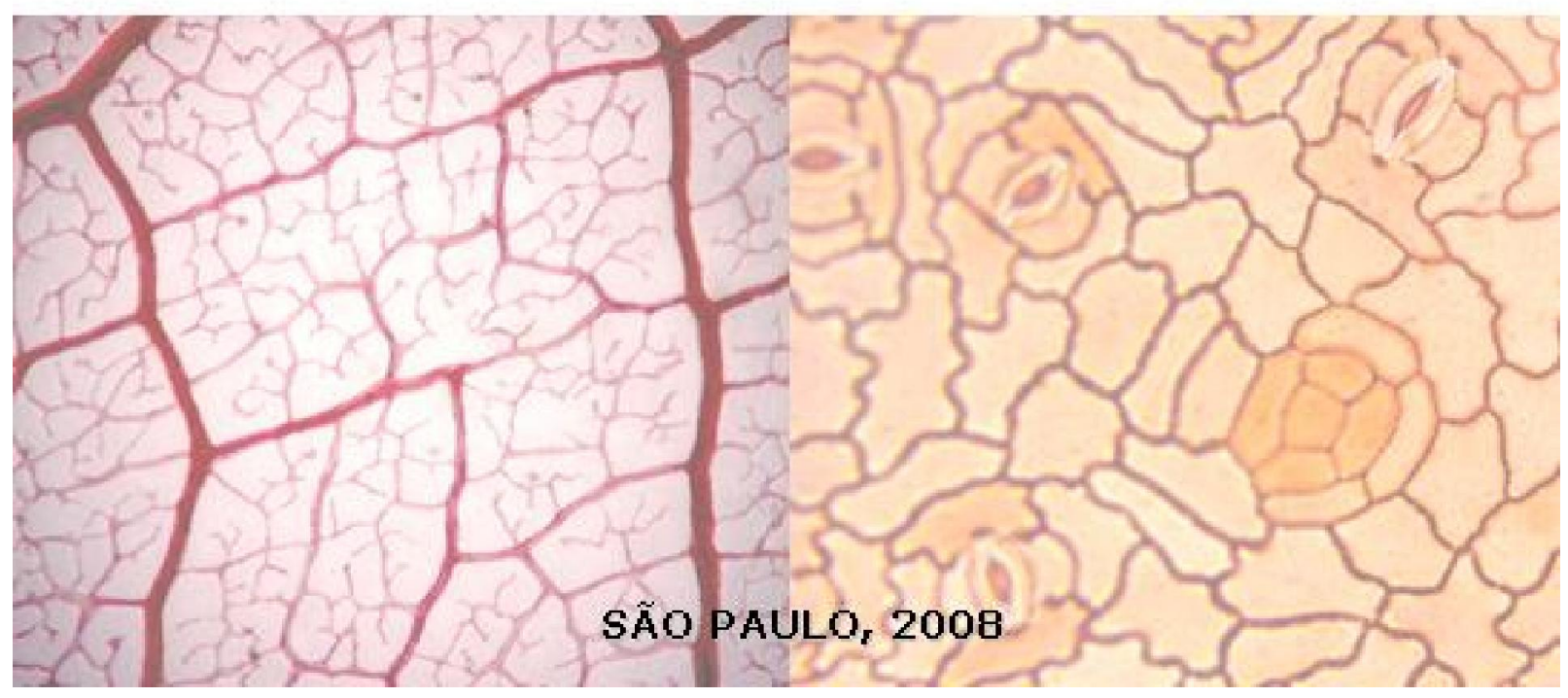




\section{DESCRIÇÃO E MAPEAMENTO DE CARACTERES MORFO- ANATOMICOS FOLIARES EM Pilocarpus VAHL (RUTACEAE) E GÊNEROS RELACIONADOS}




\section{DESCRIÇÃ̃O E MAPEAMENTO DE CARACTERES MORFO- ANATOMICOS FOLIARES EM Pilocarpus VAHL (RUTACEAE) E GÊNEROS RELACIONADOS}

Dissertação apresentada ao Instituto de Biociências da Uniwersidade de Sấo Paulo, para a obtençä́o do Título de Mestre en Ciências, na área de Botânica.

Orientaçẫo: Profa. Dra, Gladys Flávia A. Melo de Pinna 
Muntoreanu, T. G.

Descrição e Mapeamento de caracteres morfo-anatômicos

Foliares em Pilocarpus Vahl (Rutaceae) e gêneros relacionados. 98P.

Dissertação (Mestrado) - Instituto de Biociências da Universidade de São Paulo, Departamento de Botânica

1. Rutaceae neotropicais 2. anatomia foliar 3. venação 4. mapeamento

\section{Comissão J ulgadora}

\section{Prof (a). Dr(a).}

Prof(a). Dr(a).

Profa. Dra. Gladys Flávia A. M elo de Pinna 
"A natureza reservou para si tanta liberdade que não a podemos nunca penetrar completamente com o nosso saber e a nossa ciência". 


\section{EU DEDICO}

Aos meus queridos pais,

A força e o amor me dirigiram pela vida e me deram as asas que precisava para voar. 


\section{AGRADECIMENTOS}

Ȧ Universidade de São Paulo - USP $\mathcal{P}$, ao Instituto de Biociências, ao Departamento de Botânica e em especial, ao Laboratório de Anatomia Vegetal pela a oportunidade de desenvolver esta dissertação e contribuir com meu desenvolvimento profissional.

Ao Conselho $\mathcal{N a c i o n a l}$ de Desenvolvimento Científico e Tecnológico (CN(Pq), pela concessão de bolsa de mestrado.

À Fundação de Amparo à Pe squisa do Estado de $S$ ão Paulo-FAPES $\mathcal{P}$, pe lo auxílio financeiro dado à esse trabalho.

Aos meus queridos pais, Reynaldo e Genuina, e aos meus irmãos, Thiago e Thainá, que sempre me amaram e me apoiaram em todas as decisões da minha vida. Agora a familia cresceu, I ussara (minha cunfradinfa) e gulinha (a coisa mais linda da titia). Amo vocês!

À minha querida orientadora e amiga, Flávia-desde minfia época de Iniciação no Piauí, eu nem a confecia ainda, mas já a admirava quando lia seus trabalhos. Acho que foi coisa do destino, eu queria voltar pra $S \mathcal{P}$, fazer mestrado, e quando procurei o nome dos professores do laboratório de anatomia, vi o seu nome no site da USP... A partir desse dia, minha vida mudou... Muito obrigada pela oportunidade, por contribuir com o meu amadurecimento profissional, pelas noites de sushie de vinhos na sua casa. Você e a I ulinha moram no me u coração!!!

Ao Pedro Dias, pela elaboração do projeto, por ter me ajudado muito na época da qualific ação e por ter cole tado todo material.

Aos professores do Laboratório de Anatomia Vegetal: Verônica, Gregório, Maria Emília, e Dra. Berta, pelas discussões científicas realizadas nas nossas reuniões do laboratório e pelo agradável convívio diário. E um agradecimento especial à $\mathcal{N a n u z a , ~ p e l a ~ m a r a v i l h o s a ~ v i a g e ~ m ~ a ̀ ~} S$ erra do Cipó, pelo passeio em Embu das artes e principalmente por transmitir o amor que tem pela botânica, sou sua fãa!!

À minha querida "irmãzinha" pernambucana-paulista, essa baixinha é arretada, Emília, por todos momentos compartilhados, nesses quase 3 anos, muitas conversas, festinhas, piadas.. Admiro muito a sua força e sempre estarei por perto quando precisar... Que o mundo nos aguarde!!! Também não posso deixar de agradecer minha outra irmãzinha "peruana-brasileira", "miss mercosul", Karin, por toda sua amizade, pelas aulas de espantol e pelo carinho que sempre teve comigo... A amizade de vocês é eterna para mim!!!

Aos meus queridos amigos da pensão e da casa da laje, em especial, Guilherme, Mathieu, Bruno, Jonathas, John, Hildebrando, Edjane, Helena, e às minhas queridas amigas da "tripla- 
jornada" (Laboratório e casa), Deusita, Celina, Vanessa e Bianca. Muito obrigada a todos vocês por tornar a nossa república à extensão da casa dos nossos pais.

À Gi, técnica e amiga, pela paciência que teve em me ensinar algumas técnicas em anatomia e pelas divertidas convers as na copa.

Minflas amadas amigas, do grupo da tia $\mathcal{N a n , ~ C r i s o c a ~ e ~ P a u l e t e , ~ p o r ~ t o d o s ~ o s ~ n o s s o s ~}$ intervalos, conselhos, festinhas, viagens, sinucas, conversas filosóficas sobre a vida, etc... Vocês de ixam o dia a dia do laboratório mais divertido.

Aos queridos Marcelo, meu companteiro de susfi, e Mariane, pelas valiosas dicas sobre à dissertação... Muito obrigada!!

Aos meus queridos colegas e amigos da pós-graduação ou iniciação, Vivi gono, Giu, Marlene, Guilherme, Natália, Renatinha, Zé, Andrezão, Cris (da Flávia), Ari, Bruno, Pigozzo, goão Carlos, Luis, Poli, Carla, Karen..... pelo o dia a dia do laboratório, pelas festintras na "laje "...

Às queridas colegas e amigas que já concluíram seus estudos na pós-graduação Vera, Marli, Marina Cattai, Marina Milanelo, Luciana, Adriana e Érica, pelo dia a dia do laboratório e pelas as conversas informais na copa e na sala de pós.

Ao me u querido amigo do "IPI", $S r$. Antônio, pelo sincero e carintıso laço de amizade.

Aos amigos da sistemática, Euder, guliana e Cíntia, pela deliciosa compantia na viagem à serra do Cipó.

À todos os funcionários da secretaria, Carlos, Noberto e Cesário, ao pessoal da limpeza, e mespecial à $S$ usi.

Aos meus familiares do Piauí, em especial, à minha vozinha Bella, e aos meus amigos de Itu....

Enfim, à todos vocês... de coração.... Muito obrigad a!!!!!!!!!!!!!!!!!!!!!!! 


\section{ÍNDICE}

Página

RESUM O

9

$\begin{array}{ll}\text { ABSTRACT } & 10\end{array}$

1. INTRODUÇÃO 11

2. OBJETIVOS 15

3. MATERIAL E MÉTODOS

3.1. M aterial Botânico 15

3.2. M etodologia 17

$\begin{array}{ll}\text { 3.2.1. A nálise morfo-anatômica } & 17\end{array}$

3.2.2. M apeamento dos caracter es anatômicos 19

\section{RESULTADOS}

4.1. A natomia da lâmina foliar 19

4.2. Venação 24

4.3. A natomia do pecíolo 26

4.4. M apeamento dos caracter es 29

5. DISCUSSÃO 34

6. CONSIDERAÇÕES FINAIS 44

7. REFERÊNCIASBIBLIOGRÁFICAS

8. FIGURAS 52 


\section{RESUMO}

A maioria dos estudos filogenéticos envolvendo Rutaceae foi baseada em dados macromoleculares e poucos utilizaram gêneros neotropicais. Uma exceção a esses trabalhos, foi a análise filogenética de Pilocarpus, um gênero de Rutaceae neotropical, baseada em caracteres morfológicos proposta por Dias e colaboradores. Considerando a importância dos estudos anatômicos em análises cladísticas, os quais podem constituir uma importante fonte de informações para a própria definição de estados de caráter e conseqüente proposição de homologia primária dos caracteres, o presente estudo teve como objetivo investigar e mapear caracteres foliares para Pilocarpus e gêneros relacionados com base na anatomia vegetal. Para tanto, analisou-se a organização estrutural foliar de 12 espécies, empregando-se as técnicas usuais em anatomia vegetal à dissociação de epidermes, secções transversais e longitudinais, e diafanização, adotando-se as microscopias de luz e eletrônica de varredura. Foram descritos 32 caracteres morfo-anatômicos foliares, dentre estes podem ser citados: ornamentação da cutícula; tipos de tricomas, estômatos, estruturas secretoras, cristais e células do periciclo; características do mesofilo e da venação. Com o mapeamento destes caracteres, baseado na filogenia proposta por Dias e colaboradores, foi possível observar a tendência de alguns caracteres serem informativos para determinados terminais, ou até mesmo para o grupo Pilocarpus, propondo suas possíveis relações filogenéticas. Diante disso, observou-se a tendência de que grande parte destes caracteres sejam homoplásticos, 8 dos 32 caracteres sejam autapomórficos. Apenas os estados referente a drusas de oxalato de cálcio no parênquima paliçádico e drusas de oxalato de cálcio no pecíolo, possívelmente, representem uma sinapomorfia para Pilocarpus. Além disso, as árvores mapeadas foram agrupadas de acordo com o número de caracteres que alguns terminais apresentaram em comum. Por exemplo, Raulinoa echinata e Helietta apiculata foram os terminais que apresentaram um maior número de caracteres em comum. No entanto, não foi possível afirmar quais são os caracteres filogeneticamente informativos, sendo necessário a inclusão dos dados anatômicos à matriz de caracteres morfológicos proposta por Dias e colaboradores, a fim de que novas informações sejam geradas e/ou comprovadas. 


\section{ABSTRACT}

Most of the phylogenetics studies involving Rutaceae were based on macromolecular data and few used neotropicais generas. An exception of these works, was the phylogenetic analysis about Pilocarpus, a genus of neotropical Rutaceae, based on morphological characters proposed for Dias and collaborators. Considering the importance of the anatomical studies in cladistics, which can constitute an important source of informations for itself definition about states of character and consequent proposition of primary homology of the characters, the goals of the present study were to investigate and mapping leaves' characters for Pilocarpus and related genera based on the vegetative anatomy. For these studies, the structural leaf organization of 12 species were analysed, using the usual techniques in vegetative anatomy to the dissociation of epidermis, cross and longitudinal sections and diafanization, adopting the Optical microscopy and scanning electron microscopy. Thirty two morfo-anatomical leaves characters were described: ornamentation of the cuticle; kind of trichomes, stomata, secretory structures, crystals and cells of the pericycle; characteristics of the mesophyll and venation. With the mapping of these characters, based on the phylogenetic proposed by Dias and collaborators, was possible to observe the tendency of some characters to be informative for determined taxons, or even for the group Pilocarpus, proposing its possible relations Phylogenetic. With this, was observed the tendency of what great part of these characters be homoplastics, 8 of 32 characters are autapomorphic. Druse calcium oxalate in the palisade parenchyma and in the petiole, possibly, represent a synapomorphic traits for Pilocarpus. Beside this, the mapped trees were grouped in accordance with the number of characters that some taxons presented in common. For example, Raulinoa echinata and Helietta apiculata were the species that presented the biggest number of characters in common. However, it was not possible to affirm what the characters are phylogenetic informative, being necessary the inclusion of the anatomical data to the matrix of morphological characters proposed by Dias and collaborators, so that new informations are produced and / or proved. 


\section{INTRODUÇÃO}

A família Rutaceae inclui cerca de 150 gêneros e 1500 espécies, com ampla distribuição nas regiões tropicais e temperadas do mundo todo, sendo abundante na Austrália e sul da África (Cronquist 1988). No Brasil, são 32 gêneros nativos de Rutaceae com 154 espécies (Pirani 1999). Os representantes da família apresentam hábito muito variado, desde árvores, arbustos até ervas, sendo rara esta última condição (Cronquist 1981).

Segundo Pirani (1999), o posicionamento de Rutaceae nos sistemas modernos de classificação é colocado em Rutales senso stricto (Takhtajan 1980, 1996; Dahlgern 1980) ou em Sapindales senso lato (Cronquist 1981, 1988; Thorne 1992). O mesmo autor ainda menciona que recentes análises filogenéticas baseadas em dados macromoleculares (DNA), feita por Gadek et al. (1996), vieram confirmar a provável monofilia da família Rutaceae e sua inclusão na igualmente monofilética ordem Sapindales.

Adicionalmente, a monofilia da ordem Sapindales é indicada pelas sinapormorfias de folhas compostas pinadas (ocasionalmente podem ser compostas palmadas, trifolioladas ou unifolioladas) e flores com um disco nectarífero bem desenvolvido (Judd et al. 2002). Cronquist (1981) adiciona outras características para os membros de Sapindales, como: androceu haplostêmone ou diplostêmone e ovário sincárpico com um número limitado de óvulos em cada lóculo, geralmente 1 ou 2.

Judd et al. (2002) menciona que Sapindales é composta por 9 famílias e cerca de 5800 espécies, sendo as famílias mais representativas: Anacardiaceae, Burseraceae, Meliaceae, Rutaceae, Sapindaceae e Simaroubaceae. Trabalhos de Gadek et al. (1996) e Soltis et al. (2000), baseados na seqüência do DNA, mostram que Meliaceae + Rutaceae +Simaroubaceae formam um clado. O principal caráter que separa Rutaceae das outras famílias é a presença de pontuações translúcidas nas folhas, que correspondem a cavidades glandulares multicelulares produtoras de óleos essenciais aromáticos (Metcalfe \& Chalck 1950; Heywood 1993; Judd et al. 2002).

De acordo com a revisão feita por Scholz (1964) baseada em trabalhos anteriores feitos por Engler (1874, 1896 e 1931), a família Rutaceae está dividida em 7 subfamílias:

1. Subfamília Rutoideae. Trata-se da maior subfamília. Compreende cerca de 86 gêneros distribuídos em 5 tribos (Zanthoxyleae, Ruteae, Boronieae, Diosmeae e Galipeae), sendo bem representado no Brasil os gêneros: Zanthoxylum, 
Pilocarpus, Esenbeckia, Metrodorea, Galipea, Raputia, Neoraputia, Conchocarpus e Spiranthera.

2. Subfamília Dictyolomatoideae. Sufamília monogenérica (Dictyoloma), representada por 2 espécies no Brasil e no Peru.

3. Subfamília Flinder sioideae. Constituído por 2 gêneros, Chloroxylon e Flindersia, não representados na América.

4. Subfamília Spathelioideae. Atualmente, após estudo de Cowan \& Brizicky (1960), possui um único gênero (Spanthelia), possuindo representantes no Brasil.

5. Subfamília Toddalioideae. Contém uma só tribo com 5 subtribos e cerca de 24 gêneros, representada no Brasil por Helietta, Balfourodendron e Hortia.

6. Subfamília Citroideae (=A urantioideae). Compreende 1 tribo (Aurantieae) com 30 gêneros sem representantes nativos no Brasil. O representante mais conhecido é Citrus.

7. Subfamília Rhabdodendroideae. Esta última subfamília foi definitivamente excluída de Rutaceae por autores como Prance (1972), Takhjan (1980) e Cronquist (1981), sendo elevado à categoria de família (Rhabdodendraceae), constituído pelo gênero Rhabdodendron, com 2 espécies na Amazônia brasileira.

Diversos representantes da família Rutaceae são utilizados comercialmente. Sem dúvida, o gênero Citrus é o mais conhecido de toda a família, sendo cultivado no mundo todo, com espécies e híbridos produzindo frutos comestíveis como: laranja, limão, lima, tangerina entre outras (Heywood 1993). Algumas espécies também são ornamentais, como: Ravenia spectabilis, Murraya paniculata,. Segundo Pirani (1999a), algumas espécies fornecem madeiras com boas propriedades técnicas, mas em geral não tem grande importância comercial e são de uso local, citando-se: as tamanqueiras (Zanthoxylum spp.), as arapocas (Raputia e Neoraputia spp. E Galipea spp.), o guarantã (E senbeckia leiocarpa) e o pau-marfim (Balfourodendron riedelianum).

Na medicina, Pilocarpus (“jaborandis”, subtribo Pilocarpinae) é um dos gêneros mais importantes economicamente dentre as Rutaceae neotropicais, conhecido na indústria farmacêutica por produzir pilocarpina em seu metabolismo secundário, sendo utilizada no tratamento do glaucoma.

Alguns trabalhos de revisão taxonômica de Pilocarpinae foram desenvolvidos como o de Kaastra (1982), Skorupa (1996) para Pilocarpus, e Pirani (1998) para Balfourodendron Mello ex Olliver e Helietta Tul. (subtribo Pteleinae) 
Atualmente, são reconhecidas 17 espécies de Pilocarpus, distribuídas do sul do México ao Brasil e Argentina. O Brasil abriga 13 espécies, sendo que 11 delas ocorrem exclusivamente no território brasileiro (Skorupa 1996). Seus representantes ocorrem em várias formações vegetacionais, tais como florestas estacionais, cerrados, caatingas e restingas e diferem dos outros gêneros (Esenbeckia Kunth, M etrodorea A. St.-Hil. e Raulinoa Cowan) da mesma subtribo, todos exclusivamente neotropicais, por apresentarem racemos e anteras com glândulas dorsais.

Dentre os trabalhos de filogenia publicados até o momento para Rutaceae, Pilocarpus encontra-se representado por apenas uma espécie nos trabalhos de Chase et al. (1999) e Groppo Jr. (2004), sendo que ambos utilizaram dados macromoleculares. Na árvore apresentada por Chase et al. (loc. cit.), Pilocarpus emerge como irmão de Choisysa (gênero do velho mundo), o que é resultante da não inclusão de outros gêneros neotropicais. Já na análise feita por Groppo Jr. (loc. cit.), apesar de serem incluídos vários gêneros de Rutaceae neotropicais, a árvore apresentou uma politomia para os grupos neotropicais, a qual deve ser mais explorada.

Entretanto, Dias e colaboradores (submetido) apresentaram uma análise filogenética para Pilocarpus, sendo a primeira para um gênero neotropical em Rutaceae. Adicionalmente, é a primeira análise filogenética para a família a usar apenas caracteres morfológicos e elaborada sob abordagem bayesiana. Neste trabalho, o monofiletismo para Pilocarpus foi fortemente sustentado, e o uso de dados morfológicos mostrou-se como uma importante fonte de informação filogenética.

Não obstante, esse e os outros estudos têm negligenciado de um modo geral os dados anatômicos, os quais podem constituir uma importante fonte de informações para a própria definição de estados de caráter e conseqüente proposição de homologia primária dos caracteres (Dias et al. submetido).

Até o momento, existem poucos trabalhos publicados sobre a anatomia foliar de representantes de Rutaceae. Dentre esses trabalhos, destaca-se o de Liu \& Hu (1998), no qual foram estudadas a estrutura e a ontogênese das cavidades secretoras de 22 gêneros, 40 espécies e 2 variedades de Rutaceae da China; os autores, então, discutem seus dados à luz das possíveis relações entre as subfamílias e entre os gêneros de Rutaceae. Adicionalmente, Ogundipe (2002) também se destaca por apresentar caracteres anatômicos úteis na delimitação infragenérica de Zanthoxylum L., tais como a organização do mesofilo, a distribuição dos estômatos e os padrões de venação. 
Considerando apenas Pilocarpus, os estudos anatômicos mais recentes restringem-se ao de Marquete (1981), no qual foram estudadas as estruturas do pecíolo, lâmina e nervuras de P. organensis Occhioni \& Rizzini (= P. pauciflorus A. St.-Hil.); o de Gallardo \& Jiménez (2002), no qual foi analisada a anatomia foliar de Pilocarpus goudotianus Tul. (=P. racemosus Vahl) onde foram descritas características xeromórficas; e de Spegazzini e colaboradores (2002), no qual foi feita uma micrografia foliar quali-quantitativa de três espécies de Pilocarpus, a fim de encontrar caracteres diagnósticos aos referidos táxons. Como pode ser notado, entretanto, nenhum dos trabalhos citados não foram executados sob o paradigma filogenético.

Segundo Judd (2002), os caracteres morfológicos são usados para hipotetizar relações filogenéticas, podendo ser encontrados em todas as partes das plantas, vegetativas e reprodutivas. Carlquist (1961 apud Dickison 2000) menciona que as folhas são órgãos anatomicamente variáveis, e que esta variação é, às vezes, específica para gêneros, espécies ou mesmo família. Dickison (1975), em seu trabalho sobre as bases da filogenia em angiospermas, menciona que numerosos caracteres anatômicos dentro das folhas tem tido um valor sistemático em diferentes linhagens, citando como exemplo características da cutícula e da epiderme; tipos de tricomas e estômatos; características do mesofilo (tipos, formas das células, números de camadas); presença de estruturas secretoras e cristais; padrão de venação e arranjo do sistema vascular na folha e no pecíolo.

Para Rutaceae, até o momento, não há nenhum trabalho publicado que tenha utilizado dados anatômicos em análises cladísticas. No entanto, pode-se citar alguns trabalhos com outras famílias de angiospermas que utilizaram caracteres anatômicos foliares na filogenia (ex. Aliscioni 2002; Landrum 2002; Mello-Silva 2005).

Considerando a importância dos estudos anatômicos em análises cladísticas, insere-se a presente proposta de investigação e mapeamento de caracteres foliares para Pilocarpus e gêneros relacionados com base na anatomia vegetal. Esta proposta constitui o primeiro esforço para a delimitação anatomicamente embasada de estados de caracteres em gêneros de Rutaceae neotropicais. 


\section{OBJETIVOS}

O presente estudo objetiva elucidar aspectos morfo-anatômicos foliares para Pilocarpus (Rutaceae) e gêneros relacionados a fim de:

1-) Contribuir com o conhecimento anatômico de alguns gêneros de Rutaceae neotropicais, pouco descrito na literatura;

2-) Levantar e analisar os caracteres morfo-anatômicos ocorrentes no grupo, além de relacioná-los com o ambiente em que vivem;

3-) Mapear tais caracteres, baseado na filogenia proposta por Dias e colaboradores, a fim de identificar possíveis caracteres informativos, para que no futuro, estes possam ser utilizados em estudos filogenéticos do grupo.

\section{MATERIAL E MÉTODOS}

\subsection{MATERIAL BOTÂNICO}

Dos vinte e três terminais propostos na filogenia por Dias et al. (submetido) foram estudados doze, sendo seis representantes de Pilocarpus e seis de gêneros relacionados (Figs. 1-7). A lista de espécies, com os respectivos vouchers, localidades e tipo de vegetação, encontra-se na tabela 1.

Parte dos ramos coletados foi fixado em FAA 50 - formaldeído, ácido acético e etanol $50 \%$ - (Johansen 1940) e estocado em etanol 70\%, e a outra parte, encontra-se depositado no Herbário do Departamento de Botânica do Instituto de Biociências da Universidade de São Paulo (SPF). 
Tabela 1: Lista das espécies estudadas, suas respectivas localidades, vegetação e vouchers.

\begin{tabular}{|c|c|c|c|c|}
\hline $\begin{array}{l}\text { SUBFAMÍLIA/ } \\
\text { TRIBO/ } \\
\text { SUBTRIBO }\end{array}$ & ESPÉCIES & VOUCHER & $\begin{array}{l}\text { LOCALIDADE } \\
\text { CIDADE - ESTADO }\end{array}$ & VEGETAÇÃO \\
\hline $\begin{array}{l}\text { Rutoidea/ } \\
\text { Galipea/ } \\
\text { Cuspariinae }\end{array}$ & Galipea trifoliata Aubl. & $\begin{array}{l}\text { P. Dias } 230 \\
\text { P. Dias } 231\end{array}$ & $\begin{array}{l}\text { Presidente Médice - } \\
\text { RO } \\
\text { Ouro Preto D’Oeste - } \\
\text { RO }\end{array}$ & Floresta ombrófila densa \\
\hline \multirow{9}{*}{$\begin{array}{l}\text { Rutoidea/ } \\
\text { Galipea/ } \\
\text { Pilocarpinae }\end{array}$} & Pilocarpus alatus Joseph ex Skorupa & P. Dias 247 & Buriticupu - MA & Floresta ombrófila densa \\
\hline & Pilocarpus jaborandi Holmes & $\begin{array}{l}\text { P. Dias } 252 \\
\text { P. Dias } 253 \\
\text { P. Dias } 254\end{array}$ & Viçosa do Ceará - CE & Brejo de altitude \\
\hline & Pilocarpus microphyllus Stapf ex Wardl. & $\begin{array}{l}\text { P. Dias } 235 \\
\text { P. Dias } 237 \\
\text { P. Dias } 238\end{array}$ & Parauapebas - PA & $\begin{array}{l}\text { "Canga" (vegetação savânica sobre minas de } \\
\text { minério) }\end{array}$ \\
\hline & Pilocarpus pauciflorus A. St.-Hil. & P. Dias 218 & Piracicaba - SP & Mata mesófila semi-decídua \\
\hline & Pilocarpus giganteus Engler & P. Dias 337 & Linhares - ES & "Mussununga" (veg. savânica arbustivo-arbórea) \\
\hline & Pilocarpus spicatus A. St.-Hil. & $\begin{array}{l}\text { P. Dias } 206 \\
\text { P. Dias } 325\end{array}$ & Caetité - BA & Mata de galeria \\
\hline & Raulinoa echinata Cowan & $\begin{array}{l}\text { P. Dias } 257 \\
\text { P. Dias } 258 \\
\text { P. Dias } 259\end{array}$ & Apiúna - SC & Mata ciliar \\
\hline & E senbeckia leiocarpa Engler & P. Dias 214 & Piracicaba - SP & Cultivado \\
\hline & Metrodorea flavida K. Krause & P. Dias 229 & Alvorada D’Oeste - RO & Floresta ombrófila densa \\
\hline Toddalioideae/ & Balfourodendron riedelianum Engler & $\begin{array}{l}\text { P. Dias } 217 \\
\text { P. Dias } 345\end{array}$ & Piracicaba - SP & Cultivado \\
\hline $\begin{array}{l}\text { Toddalieae/ } \\
\text { Pteleinae }\end{array}$ & Helietta apiculata Bentham & $\begin{array}{l}\text { P. Dias } 216 \\
\text { P. Dias } 344\end{array}$ & Piracicaba - SP & Cultivado \\
\hline
\end{tabular}




\subsection{METODOLOGIA}

\subsubsection{A nálise morfo-anatômica}

Para o presente estudo foram analisadas as regiões da lâmina foliar e do pecíolo. No primeiro caso, foram feitos cortes transversais e longitudinais da região mediana da folha ou folíolo totalmente expandido. Para o estudo anatômico do pecíolo, utilizou-se inicialmente a região basal. Mas em algumas espécies analisadas surgiu uma dúvida em relação ao estado de caráter do sistema vascular, sendo necessário seccionar o pecíolo até a região mediana, para que esta dúvida pudesse ser solucionada.

Para estas secções histológicas, foram aplicadas tanto as técnicas de cortes à mão como a de inclusão em parafina (Johansen 1940).

Nos cortes à mão, os segmentos transversais e longitudinais foram clareados em água sanitária a $50 \%$, corados com safranina $1 \%$ em etanol $50 \%$ e azul de astra $1 \%$ em etanol $50 \%$ (Bukatsch 1972) e montados em lâminas semi-permanentes com glicerina a 50\% (Purvis et al. 1964).

Para os cortes incluídos na parafina, o material em etanol $70 \%$ foi colocado no dessecador durante dois dias para a retirada de ar. Após a retirada de ar, a infiltração seguiu o seguinte protocolo: desidratatação em série etanol/álcool butílico terciário (50-100\%), deixando o material por duas horas em cada série; overnight em butanol P.A. (puro); início da infiltração em série butanol P.A./parafina $(3: 1 ; 1: 1 ; 1: 3)$, com trocas a cada duas horas; parafina pura por quatro horas; material emblocado em caixinhas de papel.

Após o emblocamento, o material foi seccionado em micrótomo rotativo em séries transversais e longitudinais, na espessura média de 10-12 $\mu \mathrm{m}$, sendo distendido e aderido em lâminas histológicas. Posteriormente, estas lâminas foram desparafinadas em acetato de butila a $60^{\circ} \mathrm{C}$ por duas horas, e coradas com safranina $1 \%$ em etanol $50 \%$ e azul de astra $1 \%$ em etanol 50\% (Bukatsch 1972). Lâminas permanentes foram montadas utilizando resina sintética "Entellan".

Para determinar o tipo de estômato, utilizou-se a técnica de dissociação da epiderme com peróxido de hidrogênio e ácido acético 1:1 (Franklin 1945) e sua descrição baseou-se nos critérios propostos por Radford et al. (1974).

Para a observação da ornamentação cuticular e detalhes dos tricomas e estômatos, utilizou-se à microscopia eletrônica de varredura (MEV). Os segmentos da lâmina foliar 
foram desidratados em série etanólica e submetidos a ponto crítico. Posteriormente, foram aderidos a suportes metálicos e cobertos com ouro, conforme o procedimento usual no MEV descrito por Silveira (1989).

Os padrões da vascularização foliar foram determinados a partir de lâminas foliares diafanizadas empregando-se a técnica de Strittmater (1973), onde o material foi fervido por três minutos em etanol $95 \%$ e depois novamente fervido por mais três minutos numa solução de Hidróxido de sódio 5\% e etanol 95\%. Em seguida, as folhas foram lavadas em água destilada e clarificadas na solução de hipoclorito de sódio a 50\% (o tempo variou de espécie para espécie). O material foi lavado novamente na água destilada, desidratado em série etanólica e corado com safranina $1 \%$ em etanol $70 \%$. As folhas foram distendidas em placas de vidro, tendo como meio de montagem resina Entellan ou Bálsamo-do-Canadá.

Para a descrição e classificação dos padrões de nervação foram utilizados dois autores: os tipos básicos definidos por Hickey (1979), para o desenvolvimento da aréola, venação última marginal e terminações vasculares; e a terminologia do LAWG (1999), para o espaçamento e ângulos entre as nervuras secundárias; classificação das intersecundárias; e categorias das nervuras terciárias e quaternárias.

Para visão geral das folhas diafanizadas foi preciso fotografar com a máquina Leica MDA estativa, utilizando uma caixa de luz por baixo destas placas (negatoscópio). Posteriormente as fotos foram digitalizadas e trabalhadas no software de editor de imagem Paint.

Os esquemas do pecíolo foram desenhados à mão, utilizando uma fotomicrografia da região como modelo. Posteriormente, este desenho foi digitalizado e trabalhado no software de editor de imagem Adobe Photoshop 6.0 (Adobe Systems 2002).

Tanto na folha como no pecíolo, algumas espécies não apresentaram cristais nos cortes transversais, sendo necessário a realização de macerados com a técnica proposta por Franklin (1945), para confirmar a ausência destes cristais. Para verificar a composição química dos cristais foi utilizado o teste com ácido acético glacial, para a distinção entre carbonato de cálcio e oxalato de cálcio (Kraus et al. 1998).

As análises anatômicas das folhas e dos pecíolos foram realizadas em microscópio óptico com as principais estruturas registradas no Sistema de Digitalização de Imagens (IM50) acoplado ao microscópio Leica DMBL, sendo este também utilizado para a constatação da presença de cristais através do uso da luz polarizada. 


\subsubsection{M apeamento dos caracteres anatômicos}

Após a delimitação dos caracteres anatômicos da folha e do pecíolo, utilizou-se o programa MacClade 4.0 (Maddison \& Maddison 2000). Com este programa foi possível: montar a matriz, onde os caracteres anatômicos multiestados não foram ordenados e não tiveram pesos diferentes; desenhar o cladograma de Pilocarpus e gêneros relacionados de acordo com a filogenia proposta por Dias et al. (submetido); e mapear os dados da matriz na árvore desenhada, analisando a evolução dos caracteres.

É importante mencionar que somente 12 dos 23 terminais propostos na filogenia por Dias et al. (submetido) é que foram analisados. Os 11 terminais que não foram analisados, estes foram acrescentados na matriz, e seus estados foram simbolizados por uma interrogação (?). Isso foi feito, porque o programa utilizado para o mapeamento consegue reconstruir a história evolutiva dos caracteres, inferindo no possível estado de caráter das espécies ancestrais da árvore. Além disso, 3 dos 32 caracteres levantados, possuíram estados que não se aplicam em alguns terminais analisados, sendo simbolizados por um traço (-).

\section{RESULTADOS}

\subsection{A natomia da lâmina foliar}

\subsubsection{A nálise em varredura da superfície foliar}

Caráter 1 - Ornamentação da cutícula foliar na face adaxial: lisa (0); estriada (1) Caráter 2 - Ornamentação da cutícula foliar na face abaxial: lisa (0); estriada (1)

De acordo com a análise obtida pela microscopia de varredura, as espécies apresentam, por toda a extensão da face adaxial, uma cutícula ornamentada com finas estrias (Figs. 8-10) exceto em Galipea trifoliata e Raulinoa echinata (Fig. 11), as quais apresentam a cutícula lisa. Já na face abaxial, apenas Pilocarpus pauciflorus, Raulinoa echinata e Balfourodendron riedelianum não apresentam cutícula com estrias. Nas demais espécies, a cutícula pode ocorrer por toda a face, como em Esenbeckia leiocarpa (Fig. 12), ou estar presente próximo a alguns estômatos e tricomas, como nas demais espécies (Fig. 13). Em uma mesma espécie, como em G. trifoliata, observam-se estômatos circundados com e sem a cutícula estriada (Figs. 13-14). Adicionalmente, a forma como estas cutículas circundam o estômato, não 
apresenta um padrão por espécie (Figs. 15-16). Em algumas espécies, como em Pilocarpus microphyllus, a cutícula estriada se estende, ligando um estômato a outro (Fig. 17).

\subsubsection{Tricomas}

Caráter 3 - Tricoma tector na lâmina foliar: ausente (0); presente (1)

Em ambas as faces da epiderme, tricomas tectores e glandulares foram observados (Fig. 18). O tricoma tector é do tipo unicelular filiforme presente em quase todas as espécies (Figs. 18-19), exceto Raulinoa echinata.

Todas as espécies apresentam tricomas glandulares, podendo ser capitados ou peltados.

Caráter 4 - Tipos de tricomas glandulares capitados na lâmina foliar: pedúnculo multicelular unisseriado, com região apical unicelular (0); pedúnculo multicelular unisseriado com região apical multicelular (1); Pedúnculo unicelular com região apical unicelular (2); pedúnculo unicelular com região apical multicelular (3)

Os tricomas capitados consistem de uma célula basal, uma ou várias células pedunculares, com parede externa cutinizada, e a região apical que pode ser uni ou multicelular. Diante do número de células do pedúnculo e do ápice, os tricomas capitados diferem em quatro tipos:

1- pedúnculo multicelular unisseriado, com região apical piriforme unicelular em G . trifoliata (Figs. 20-21);

2- pedúnculo multicelular unisseriado inserido em depressão na epiderme, com a região apical circular multicelular em E . leiocarpa (Figs. 22-23);

3- pedúnculo unicelular localizado entre as células na epiderme, com região apical globular unicelular de paredes delgadas em Pilocarpus spicatus (Fig. 24), Pilocarpus giganteus, Pilocarpus pauciflorus (Fig. 25) e Pilocarpus microphyllus (Fig. 26);

4- pedúnculo unicelular, com a região apical multicelular em B. riedelianum (Figs. 2728) e H elietta apiculata.

Caráter 5 - Tricomas glandulares peltados na lâmina foliar: ausente (0); presente (1)

A lâmina foliar de Metrodorea flavida (Fig. 29), Pilocarpus jaborandi, Helietta apiculata (Fig. 30), Pilocarpus alatus e R. echinata (Figs. 31-32) possuem tricomas do tipo peltado (subséssil). Estes tricomas são constituídos por uma célula peduncular inserido em 
depressão na epiderme, e uma região apical multicelular, distribuída radialmente em dois círculos concêntricos, que envolvem a célula peduncular.

\subsubsection{Contorno das células epidérmicas em vista frontal}

Caráter 6 - Paredes das células epidérmicas na face adaxial em vista frontal: retas (0); sinuosas (1)

Caráter 7 - Paredes das células epidérmicas na face abaxial em vista frontal: retas (0); sinuosas (1)

Em vista frontal (Figs. 33-56), as células epidérmicas, em ambas as faces, possuem paredes retas na maioria das espécies (Figs. 34, 37-43, 46, 49-55). Paredes sinuosas, tanto na face abaxial como na adaxial, ocorrem em G. trifoliata (Figs. 33, 45) e M. flavida (Figs. 35, 47), e só na face adaxial em P. alatus (Fig. 36) e P. spicatus (Fig. 44). Nas espécies em que as paredes são retas, a epiderme, em ambas as faces, apresenta o contorno variando de quadrangular a pentagonal em E. leiocarpa (Figs. 34, 46), pentagonal a hexagonal só na face adaxial em P. jaborandi (Fig. 37) e nas demais espécies variam de retangular a pentagonal (Figs. 38-43, 48-56).

\subsubsection{Estômatos}

\section{Caráter 8 - Tipos de estômatos: anomocítico (0); tetracítico (1)}

As folhas de todas as espécies são hipostomáticas (Figs. 45-56), observando-se dois tipos: anomocítico em G. trifoliata (Fig. 45), E. leiocarpa (Fig. 46), M. flavida (Fig. 46), P. microphyllus (Fig. 50), H. apiculata (Fig. 52), e B. riedelianum (Fig. 54); e tetracítico, com quatro células subsidiárias, sendo duas oblíquas na porção superior e duas oblíquas na porção inferior em P. alatus (Fig. 48), P. jaborandi (Fig. 49), P. pauciflorus (Fig. 51), R. echinata (Fig. 52), P. giganteus (Fig. 55) e P. spicatus (Fig. 56).

\subsubsection{Lúme das células epidér micas em secção transversal}

Caráter 9 - Relação de tamanho entre as células epidérmicas na face adaxial $x$ abaxial (secção transver sal): adaxial > abaxial (0); adaxial = abaxial (1)

Em secções transversais, todas as espécies estudadas apresentam a epiderme unisseriada, com contorno variando de quadrangular a retangular em ambas as faces (Figs. 57- 
68). As células da face adaxial têm o mesmo tamanho (lúme) das células da face abaxial em quase todos os indivíduos, exceto em G. trifoliata (Fig. 59), R. echinata (Fig. 60), H. apiculata (Fig. 66) e P. giganteus (Fig. 67), que apresentam as células da face adaxial maior do que a abaxial. Em H. apiculata (Fig. 66), algumas células da epiderme apresentam divisão periclinal da parede. Os estômatos ocupam o mesmo nível das células da epiderme em todas as espécies (Fig. 63).

\subsubsection{M esofilo}

Caráter 10 - Número de camadas do parênquima paliçádico: uma camada (0); mais de uma camada (1)

Todos os indivíduos exibem, em secção transversal, a região mediana da lâmina foliar com organização dorsiventral, sendo o parênquima paliçádico uniestratificado na face adaxial (Figs. 57-65, 67-68), com exceção de H. apiculata (Fig. 66), que possui 2-3 camadas de parênquima paliçádico.

Caráter 11 - Formato das células do parênquima paliçádico: retangular (0); paliçada (1)

As células do parênquima paliçádico têm formato de paliçada em quase todas as espécies, com exceção G. trifoliata (Fig. 59), que possui um formato mais retangular.

A proporção entre o número de células do parênquima paliçádico e o número de células da epiderme é de 1:1 em P. alatus (Fig. 63), P. giganteus (Fig. 67) e P. spicatus (Fig. 68); 3:1 em P. jaborandi (Fig. 64), B. riedelianum (Fig. 65) e H. apiculata (Fig. 66); e de 2:1 nas demais espécies (Fig. 57- 61).

Todas as espécies possuem uma camada de células coletoras entre o parênquima paliçádico e o lacunoso (Figs. 57-68). O número de camadas celulares do parênquima lacunoso varia entre cinco, como em G. trifoliata (Fig. 59), a treze em P. jaborandi (Fig. 64). Em todas as espécies, este tecido é composto por células braciformes frouxamente dispostas (Fig. 57-68), sendo que alguns indivíduos apresentam grandes espaços intercelulares no mesofilo, como em P. pauciflorus (Fig. 61), P. microphyllus (Fig. 62), P. alatus (Fig. 63) e P. jaborandi (Fig. 64).

Caráter 12 - Cavidades secretoras na folha: ausente(0); presente (1) 
Interno a epiderme, em ambas as faces, todos os indivíduos apresentam estruturas secretoras (Figs. 69-83). Esenbeckia leiocarpa (Figs. 69, 76) é a única espécie que só possui células secretoras, ao invés de cavidades, localizadas interno ao parênquima paliçádico e inseridas no parênquima lacunoso. As demais espécies possuem cavidades secretoras que apresentam, tanto em secção transversal (Figs. 69-75), como longitudinal (Figs. 76-83) da lâmina foliar, a ocorrência das células do epitélio, sugerindo que a origem destas seja esquizolisígena. As cavidades secretoras também podem ocorrer na região da nervura principal.

Caráter 13 - Cristais no parênquima paliçádico: ausente (0); presente (1)

Caráter 14 - Tipos de cristais no parênquima paliçádico: cristais em forma de bastão (0); drusas de oxalato de cálcio (1)

Quase todas as espécies possuem idioblastos com cristais no parênquima paliçádico (Figs. 84-96), exceto G. trifoliata. Esta espécie apresenta ráfides, que são melhores observadas na folha diafanizada. As células do parênquima paliçádico apresentam paredes transversais ao eixo maior da célula e contém drusas de oxalato de cálcio em todas as espécies de Pilocarpus (Figs. 84-86, 91-92), e cristais em forma de bastonete nos demais gêneros (Figs. 87-88, 93-94). Os cristais também podem estar distribuídos no parênquima lacunoso (Fig. 86), no periciclo (Figs. 89-90) e no floema (Figs. 95-96) na região da nervura principal.

\subsubsection{Contorno da nervura principal}

Na região da nervura principal (Figs. 97-120) de algumas espécies estudadas, como M . flavida, P. alatus, P. giganteus, P. spicatus, G. trifoliata e B. riedelianum, as folhas são biconvexas (Figs. 97-102). Entretanto, em E. leiocarpa, R. echinata, P. pauciflorus e P. jaborandi apresentam a face adaxial plana e a abaxial, convexa (Fig. 103-106), embora em E . leiocarpa (Fig. 103) a face adaxial possa apresentar uma discreta convexidade. Em P. microphyllus e H. apiculata a superfície adaxial é convexa e a abaxial, plana (Fig. 107-108). Estudos preliminares em ápice e base foliar destas espécies mostram que o contorno da nervura mediana pode variar em uma mesma espécie. Por exemplo, em P. jaborandi, na base foliar o contorno é biconvexo, enquanto que no meio e no ápice é plano-convexo (Fig. 106). Além disso, P. pauciflorus e H. apiculata também apresentam variação do contorno na nervura ao longo da lâmina foliar. No entanto, $P$. alatus e P. spicatus mantêm o mesmo padrão biconvexo na base, meio e ápice. Portanto, o contorno da nervura principal não pode ser usado como caráter, uma vez que numa mesma espécie, o estado não se mantém constante. 


\subsubsection{Sistema vascular}

Caráter 15 - Forma do sistema vascular (unidade vascular) na lâmina foliar: aberto (0); fechado (1)

A forma do sistema vascular (unidade vascular) na nervura mediana apresenta-se como um arco fechado em quase todas as espécies, com exceção a P. microphyllus que é aberto (Figs. 108, 115). Em M. flavida (Figs. 98, 111) e P. alatus (Figs. 99, 113), mesmo apresentando um arco fechado, observa-se que há um encontro entre as células com paredes secundárias lignificadas do periciclo (provavelmente fibras pericíclicas) e as fibras do xilema.

A unidade vascular central é do tipo colateral em todas as espécies (Figs. 97-120), variando na continuidade das fibras pericíclicas que circundam os feixes. No entanto, em $E$. leiocarpa (Fig. 109) se observa que, na região mediana da lâmina foliar, estas fibras ainda não estão completamente diferenciadas, mas analisando a base foliar, as fibras estão diferenciadas. Presença de medula formada por células parenquimáticas em todos os representantes.

\subsubsection{Domácias}

\section{Caráter 16 - Domácias: ausente (0); presente (1)}

Domácias foram registradas somente em Balfourodendron riedelianum (Figs. 121126), estando presentes nas axilas da nervura mediana, na face abaxial da lâmina foliar (Figs. 121-122). Estas estruturas estão em toda a extensão da lâmina, sendo do tipo em cripta. Observa-se que a cripta é formada apenas pela redução do parênquima lacunoso (Figs. 123124). Tricomas tectores unicelulares estão presente apenas próximo à região de abertura da cripta (Figs. 121-122, 125-126).

\subsection{V enação}

Em todas as folhas estudadas, o tipo de venação é pinado, ou seja, possui uma única nervura primária. Além disso, todas apresentam um padrão de nervação foliar do tipo camptódromo-broquidódromo, onde as nervuras secundárias formam uma série de arcos próximos ao bordo da lâmina foliar (Figs. 127-133). 
Caráter 17 - Ângulo das nervuras secundárias: uniforme (0); aumenta em direção à base (1); diminui em dir eção à base (2)

O espaçamento entre as nervuras secundárias é irregular em todas as espécies. No entanto, o ângulo formado por estas nervuras pode aumentar em direção a base da folha, como em P. jaborandi (Fig. 132) e B. riedelianum; diminuir em direção a base, como em M . flavida e H. apiculata (Fig. 129); ou permanecerem uniformes por toda a folha, como observado nas demais espécies (Figs. 127, 128, 130, 131 e 133)

Caráter 18 - Ocorrência de intersecundárias: ausente (0); fraca (1); forte (2)

A maioria das espécies apresenta nervuras intersecundárias, que tem largura e percurso similar às nervuras secundárias, mas diferem por serem mais finas e não alcançarem à margem. As intersecundárias podem ser fracas (Figs. 128-130), como em G. trifoliolata, P. alatus, M. flavida, H. apiculata, B. riedelianum, R. echinata; ou fortes (Figs. 127, 131-133), como nas demais espécies de Pilocarpus. Somente E. leiocarpa não possui intersecundárias.

Caráter 19 - Venação última marginal: incompleta (0); em forma dearco (1)

A venação última marginal - "marginal ultimate venation" é incompleta, formada por terminações vasculares livres nas folhas de P. microphyllus (Fig. 134), P. alatus (Fig.135), H. apiculata (Fig. 136), E. leiocarpa (Fig. 137), B. riedelianum. Nas demais espécies, a venação última marginal é na forma de arco (Figs. 138-143).

Caráter 20 - Categoria da nervura terciária: aleatoriamente reticulada (0); dicotomizada (1); pecurrente alternada (2)

As nervuras terciárias e quaternárias também possuem uma classificação de acordo com o arranjo que compõem a folha. Nas espécies estudadas, as nervuras terciárias são do tipo: percurrente alternada - "alternate percurrent”, onde as terciárias cruzam as secundárias com uma brusca descontinuidade angular, como nas demais espécies (Fig. 144-146); dicotomizada - "dichotomizing”, onde as terciárias são ramificadas livremente, como em P. microphyllus (Fig. 147) e aleatoriamente reticulada - "random reticulate", no qual estas nervuras se unem com outras terciárias ou secundárias como em H. apiculata (Fig. 148) e R. echinata (Fig.149).

Caráter 21 - Categoria da nervura quaternária: reticulada poligonal regular (0); dicotomizada (1); pecurrente alternada (2) 
Quanto às nervuras quaternárias, as folhas estudadas também apresentam 3 tipos: reticulada regular poligonal - "regular polygonal reticulate", onde as quaternárias se unem com outras nervuras formando polígonos de tamanho e forma regular, presente em $G$. trifoliata (Fig. 145) e P. pauciflorus; dicotomizada - "dichotomizing", no qual as quaternárias são ramificadas livremente e são a mais perfeita ordem que a folha exibe, como em $P$. microphyllus (Fig. 147), P. alatus, H. apiculata (Fig. 148) e R. echinata (Fig.149); e nas demais espécies, percurrente alternada - "alternate percurrent” (Figs. 144, 146).

Caráter 22 - Desenvolvimento das aréolas: incompleta (0); imperfeita (1)

As aréolas, determinadas pelas nervuras terciárias e de ordem superior, são classificadas de acordo com o seu desenvolvimento podendo ser de 4 tipos: bem desenvolvida, imperfeitas, incompletas e ausentes. A maioria das folhas estudadas apresenta a aréola imperfeita (Fig. 150-155), onde as nervuras formam malhas de formato irregular, mas não variando muito o tamanho. Entretanto, em R. echinata, H. apiculata e P. microphyllus (Figs. 156-161), a aréola é incompleta, a qual apresenta um ou mais lado da rede de nervuras não limitado, dando origem a uma grande malha de tamanhos e formas "anômalos".

\section{Caráter 23 - Terminações das nervuras: simples (0); ramificadas (1)}

$\mathrm{Na}$ mesma folha, as terminações vasculares podem ser simples ou ramificadas. Nas espécies estudadas nota-se o predomínio destas terminações serem simples, em P. jaborandi, P. alatus (Fig. 155), P. giganteus, H. apiculata (Figs. 160-161) e B. riedelianum, e ramificadas nas demais espécies (Figs. 150-154, 156-159). Em P. microphyllus (Figs. 154155), observa-se a ocorrência de idioblastos traqueoidais nas terminações vasculares.

\subsection{A natomia do Pecíolo}

Caráter 24 - Forma das células epidérmicas do pecíolo em secção transversal: quadrangular a retangular (0); papilosa (1)

A epiderme tem aspecto papiloso em H. apiculata, E. leiocarpa e P. alatus (Figs. 162165); quadrangular a retangular em $P$. pauciflorus, R. echinata, G. trifoliata, B. riedelianum, P. spicatus, P. jaborandi, P. giganteus e P. microphyllus (Figs. 166-172). Em algumas espécies, a epiderme foi parcialmente substituída pela periderme como em B. riedelianum 
(Fig. 173) ou totalmente substituída, como em M. flavida (Fig. 174), podendo apresentar lenticelas (Fig. 175).

Caráter 25 - Tricoma tector no pecíolo: ausente (0); presente (1)

A maioria das espécies apresenta tricomas, exceto P. pauciflorus e P. giganteus. Todos os indivíduos possuem tricoma tector unicelular filiforme (Figs. 162, 165, 168).

Caráter 26 - Tricoma glandular no pecíolo: ausente (0); presente (1)

Caráter 27 - Tipos de Tricomas glandulares no pecíolo: capitado (0); peltado (1)

Além do tricoma tector, duas espécies apresentam tricomas glandulares, sendo do tipo capitado em E. leiocarpa (Fig. 163) e do peltado em H. apiculata (Fig. 164), ambas com pedúnculo multicelular unisseriada e região apical multicelular.

Caráter 28 - Cavidade secretora no pecíolo: ausente(0); presente (1)

Interno a epiderme, todas as espécies apresentam estruturas secretoras, que podem ser cavidades e/ou células. As cavidades secretoras estão localizadas próximo à epiderme e provavelmente sua origem seja esquizo-lisígenas (Figs. 167, 170, 172), já as células secretoras são encontradas em toda região cortical, no xilema, no floema e na medula.

Em quase todos os representantes as duas estruturas secretoras foram observadas, exceto em E. leiocarpa, que apresenta somente células secretoras no córtex e na medula.

Além disso, células esclerenquimáticas são observadas próximo à epiderme apenas em M. flavida e P. giganteus (Figs. 175-176).

Caráter 29 - Ráfides no pecíolo: ausente (0); presente (1)

Caráter 30 - Cristais prismáticos no pecíolo: ausente (0); presente (1)

Caráter 31 - Drusas de oxalato de cálcio no pecíolo: ausente (0); Presente (1)

Todos os indivíduos apresentam idioblastos contendo cristais (Figs. 177-184), sendo drusas de oxalato de cálcio em todas as espécies de Pilocarpus (Figs. 177-180), ráfides e cristais prismáticos em G. trifoliata (Figs. 281-182), e apenas cristais prismáticos nas demais espécies (Figs. 183-184). Estes idioblastos estão presentes no córtex, sistema vascular e medular do pecíolo.

\subsubsection{Contorno do pecíolo e sistema vascular}


O contorno do pecíolo é côncavo-convexo em B. riedelianum, H. apiculata, P. spicatus, M. flavida, R.. echinata e P. alatus (Figs. 185-187, 191); plano na face adaxial e convexo na face abaxial em G. trifoliata, P. jaborandi, P. giganteus e P. microphyllus (Figs. 188, 192-195); e circular em E. leiocarpa (Fig. 196).

Quanto ao sistema vascular, são observados 2 tipos de organizações na região basal (proximal) do pecíolo: o cilindro fechado com medula ou vários cilindros livres. O primeiro tipo ocorre em G. trifoliata (Fig. 192), P. jaborandi (Fig. 193) e E. leiocarpa (Fig. 196). No segundo tipo, o sistema vascular pode ser composto por 3 cilindros vasculares livres, sendo o central mais proeminente e acompanhado por dois menores, formando um arco, como em $\mathrm{H}$. apiculata (Fig. 186), P. spicatus (Fig. 187), P. pauciflorus (Fig. 188), R. echinata (Fig. 189) e P. microphyllus (Fig. 194); ou ter mais de três cilindros vasculares livres, com o cilindro central mais proeminente do que os demais, como em B. riedelianum (Fig. 185), P. giganteus (Fig.188), M. flavida (Fig. 190), P. alatus (Fig. 191).

Entretanto, todas as espécies que possuem cilindros vasculares livres na região basal do pecíolo tornam-se, em um nível mais elevado, um único cilindro fechado e com medula (Figs. 197-215). Em P. giganteus pode ser observado esta transição, onde um dos cilindros menores está se unindo ao central (Figs.197-198). Além desta fusão dos cilindros, verifica-se que o pecíolo apresenta contorno diferente de acordo com a região. Assim, em B. riedelianum (Figs. 202-203), a região basal possui o contorno côncavo-convexo e, num plano mais acima, torna-se circular. Por este motivo o contorno do pecíolo e a forma do sistema vascular não foram utilizados como caráter.

Outra observação é que em M. flavida (Figs. 214-215), na região basal do pecíolo, onde os cilindros ainda estão livres, observa-se um pequeno feixe anfivasal que foi produzido pelo cilindro central. Na altura média do pecíolo, este feixe anfivasal aparece incluso no cilindro vascular fechado (Muntoreanu et al. em preparação).

Caráter 32 - Células do periciclo no pecíolo: parenquimática (0); esclerenquimática (1)

Todas as espécies de Pilocarpus, além de R. echinata e M. flavida, apresentam fibras pericíclicas circundando não continuamente o sistema vascular (Fig. 216-221), enquanto que nas demais espécies não foram observadas (Fig. 223-227). No entanto, em P. microphyllus (Fig. 221) e R. echinata (Fig. 222) nota-se que as fibras pericíclicas estão pouco diferenciadas na região basal do pecíolo. 


\subsection{M apeamento dos caracteres}

A lista com os 32 caracteres anatômicos descritos acima encontra-se na tabela 2 e a matriz na tabela 3 .

Tabela 2. Lista dos caracteres analisados e seus respectivos estados.

\begin{tabular}{|c|c|}
\hline & Presente (1) \\
\hline 1- Ornamentação da cutícula foliar na face adaxial & 17- Ângulo das ner vuras secundárias \\
\hline Lisa $(0)$ & Uniforme (0) \\
\hline Estriada (1) & Aumenta em direção a base (1) \\
\hline 2- Ornamentação da cutícula foliar na face abaxial & Diminui em direção a base (2) \\
\hline Lisa $(0)$ & 18- Ocorrência de inter secundárias \\
\hline Estriada (1) & Ausente (0) \\
\hline 3- Tricoma tector da folha & Fraca (1) \\
\hline Ausente $(0)$ & Forte (2) \\
\hline Presente (1) & 19- Venação última marginal \\
\hline 4- Tipos de tricomas glandulares capitados na lâmina & Incompleta $(0)$ \\
\hline foliar & Forma de arco (1) \\
\hline Pedúnculo multicelular unisseriado, com região apical & 20- Categoria da nervura terciária \\
\hline unicelular (0) & Aleatoriamente reticulada $(0)$ \\
\hline Pedúnculo multicelular unisseriado com região apical & Dicotomizada (1) \\
\hline multicelular (1) & Pecurrente alternada (2) \\
\hline Pedúnculo unicelular com região apical unicelular (2) & 21- Categoria da ner vura quaternária \\
\hline Pedúnculo unicelular com região apical multicelular (3) & Reticulado poligonal regular $(0)$ \\
\hline 5- Tricomas glandulares peltados na lâmina foliar & Dicotomizada (1) \\
\hline Ausente (0) & Pecurrente alternada (2) \\
\hline Presente (1) & 22- Desenvolvimento das ar éolas \\
\hline 6- Paredes das células epidér micas na face adaxial & Incompleta $(0)$ \\
\hline em vista frontal & Imperfeita (1) \\
\hline Retas (0) & 23- Terminações das nervuras \\
\hline Sinuosas (1) & Simples $(0)$ \\
\hline 7- Paredes das células epidér micas na face abaxial & Ramificada (1) \\
\hline em vista frontal & 24- Forma das células epidérmicas no pecíolo \\
\hline $\operatorname{Retas}(0)$ & (secção transver sal) \\
\hline Sinuosas (1) & Quadrangular a Retangular (0) \\
\hline 8- Tipos de estômatos & Papilosa (1) \\
\hline Anomocítico $(0)$ & 25- Tricoma tector no pecíolo \\
\hline Tetracítico (1) & Ausente $(0)$ \\
\hline 9- Relação de tamanho entre as células da & Presente (1) \\
\hline epiderme face adaxial $X$ abaxial no mesofilo & 26- Tricoma glandular no pecíolo \\
\hline (secção transversal) & Ausente (0) \\
\hline Adaxial > Abaxial (0) & Presente (1) \\
\hline Adaxial $=$ Abaxial $(1)$ & 27- Tipo de tricoma glandular no pecíolo \\
\hline 10- Número de camadas do parênquima paliçádico & Capitado (0) \\
\hline 1 camada $(0)$ & Peltado (1) \\
\hline Mais de 1 camada (1) & 28- Cavidade secretora no pecíolo \\
\hline 11-F or mato das células do parênquima paliçádico & Ausente $(0)$ \\
\hline Retangular $(0)$ & Presente (1) \\
\hline Cilíndrico (1) & 29- Ráfides no pecíolo \\
\hline 12- Cavidades secretoras na folha & Ausente $(0)$ \\
\hline Ausente (0) & Presente (1) \\
\hline Presente (1) & 30- Cristais prismáticos no pecíolo \\
\hline 13- Cristais no parênquima paliçádico & Ausente (0) \\
\hline Ausente $(0)$ & Presente (1) \\
\hline Presente (1) & Só cristais prismáticos (1) \\
\hline 14- Tipos de cristais no parênquima paliçádico & 31- Drusas de oxalato de cál cio (2) \\
\hline Cristais em forma de bastão $(0)$ & Ausente (0) \\
\hline
\end{tabular}


Drusas de Oxalato de cálcio (1)

15- F orma do sistema vascular foliar

Aberto (0)

Fechado (1)

16- Domácias

Ausente (0)
Presente (1)

32- Células do periciclo no pecíolo

Parenquimática (0)

Esclerenquimática(1)

Tabela 3. M atriz com caracteres anatômicos e seus respectivos estados em Pilocarpus e gêneros relacionados.

\begin{tabular}{|c|c|c|c|c|c|c|c|c|c|c|c|c|c|c|c|c|c|c|c|c|c|c|c|}
\hline \multirow{4}{*}{ Caráter } & \multicolumn{23}{|c|}{ E spécies } \\
\hline & G & $P$ & $P$ & $P$ & $P$ & $P$ & $P$ & $E$ & $\mathrm{R}$ & M & $\mathrm{H}$ & B & $P$ & $P$ & $P$ & $P$ & $P$ & $P$ & $P$ & $P$ & $P$ & $P$ & P \\
\hline & $\mathrm{t}$ & $\mathrm{m}$ & $p$ & $S$ & $\mathrm{~g}$ & a & j & I & $\mathrm{e}$ & $f$ & a & $r$ & $p$ & $\mathrm{~s}$ & $\mathrm{t}$ & C & d & g & $t$ & $p$ & $\mathrm{~m}$ & $r$ & r \\
\hline & $r$ & i & $a$ & $p$ & 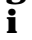 & $\mathrm{L}$ & a & $E$ & $c$ & L & 1 & i & e & u & $r$ & $a$ & $c$ & & & & a & a & i \\
\hline & & & & & & & & & & & & & $r$ & & i & & & & a & & & & \\
\hline 1 & 0 & 1 & 1 & 1 & 1 & 1 & 1 & 1 & 0 & 1 & 1 & 1 & $?$ & $?$ & $?$ & ? & ! & $?$ & ? & & $?$ & $?$ & ? \\
\hline 2 & 1 & 1 & 0 & 1 & 1 & 1 & 1 & 1 & 0 & 1 & 1 & 0 & $?$ & $?$ & $?$ & ? & ? & ? & ? & $?$ & ? & $?$ & ? \\
\hline 3 & 1 & 1 & 1 & 1 & 1 & 1 & 1 & 1 & 0 & 1 & 1 & 1 & $?$ & $?$ & $?$ & ? & ? & ? & ? & ? & $?$ & $?$ & ? \\
\hline 4 & 0 & 2 & 2 & 2 & 2 & - & - & 1 & - & - & 3 & 3 & $?$ & $?$ & $?$ & ? & $?$ & $?$ & $?$ & $?$ & $?$ & $?$ & ? \\
\hline 5 & 0 & 0 & 0 & 0 & 0 & 1 & 1 & 0 & 1 & 1 & 1 & 0 & $?$ & $?$ & $?$ & ? & $x^{\prime}$ & ? & ? & $r$ & $?$ & . & . \\
\hline 6 & 1 & 0 & 0 & 1 & 0 & 1 & 0 & 0 & 0 & 1 & 0 & 0 & $?$ & $?$ & $?$ & ? & ? & ? & ? & ? & $?$ & $?$ & ? \\
\hline 7 & 1 & 0 & 0 & 0 & 0 & 0 & 0 & 0 & 0 & 1 & 0 & 0 & $?$ & $?$ & $?$ & ? & ? & . & $?$ & $?$ & $?$ & $?$ & $?$ \\
\hline 8 & 0 & 0 & 1 & 1 & 1 & 1 & 1 & 0 & 1 & 0 & 0 & 0 & $?$ & $?$ & $?$ & ? & 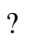 & ( & 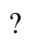 & $?$ & $?$ & ? & ? \\
\hline 9 & 0 & 1 & 1 & 1 & 0 & 1 & 1 & 1 & 0 & 1 & 0 & 1 & $?$ & $?$ & $?$ & ? & $?$ & ? & $?$ & $?$ & $?$ & $?$ & ? \\
\hline 10 & 0 & 0 & 0 & 0 & 0 & 0 & 0 & 0 & 0 & 0 & 0 & 1 & $?$ & $?$ & $?$ & ? & ! & ? & ? & ? & $?$ & $?$ & $?$ \\
\hline 11 & 0 & 1 & 1 & 1 & 1 & 1 & 1 & 1 & 1 & 1 & 1 & 1 & $?$ & $?$ & $?$ & ? & ? & ? & ? & ? & $?$ & $?$ & ? \\
\hline 12 & 1 & 1 & 1 & 1 & 1 & 1 & 1 & 0 & 1 & 1 & 1 & 1 & $?$ & $?$ & $?$ & $?$ & $?$ & $?$ & $?$ & $?$ & $?$ & ? & ? \\
\hline 13 & 0 & 1 & 1 & 1 & 1 & 1 & 1 & 1 & 1 & 1 & 1 & 1 & $?$ & $?$ & $?$ & ! & ! & ? & ? & ? & $?$ & ? & ? \\
\hline 14 & - & 1 & 1 & 1 & 1 & 1 & 1 & 1 & 0 & 0 & 0 & 0 & $?$ & $?$ & $?$ & ? & ? & ? & ? & ? & $?$ & $?$ & $?$ \\
\hline 15 & 1 & 0 & 1 & 1 & 1 & 1 & 1 & 1 & 1 & 1 & 1 & 1 & $?$ & $?$ & $?$ & $?$ & $?$ & $?$ & ? & $?$ & $?$ & $?$ & $?$ \\
\hline 16 & 0 & 0 & 0 & 0 & 0 & 0 & 0 & 0 & 0 & 0 & 0 & 1 & $?$ & $?$ & $?$ & ! & ? & ? & ? & ? & $?$ & $?$ & ? \\
\hline 17 & 0 & 0 & 0 & 0 & 0 & 0 & 1 & 0 & 0 & 2 & 2 & 1 & $?$ & $?$ & $?$ & ? & ? & ? & ? & ? & $?$ & 7 & ? \\
\hline 18 & 1 & 2 & 2 & 2 & 2 & 2 & 2 & 0 & 1 & 1 & 1 & 1 & $?$ & $?$ & $?$ & ? & ? & ? & ? & ? & $?$ & $?$ & ? \\
\hline 19 & 1 & 0 & 1 & 1 & 1 & 0 & 1 & 0 & 1 & 0 & 0 & 1 & $?$ & $?$ & $?$ & ? & ? & $?$ & ? & $?$ & $?$ & ? & $?$ \\
\hline 20 & 2 & 1 & 2 & 2 & 2 & 2 & 2 & 2 & 0 & 2 & 1 & 2 & $?$ & $?$ & $?$ & $?$ & ? & ? & $?$ & ? & $?$ & $?$ & ? \\
\hline 21 & 0 & 1 & 0 & 2 & 2 & 1 & 2 & 2 & 1 & 2 & 2 & 2 & $?$ & $?$ & $?$ & ? & ? & ? & $?$ & $?$ & $?$ & $?$ & ? \\
\hline 22 & 1 & 0 & 1 & 1 & 1 & 1 & 1 & 1 & 0 & 1 & 0 & 1 & $?$ & $?$ & $?$ & $?$ & $?$ & $?$ & $?$ & $?$ & $?$ &  & ? \\
\hline 23 & 1 & 1 & 1 & 1 & 0 & 0 & 0 & 1 & 1 & 1 & 0 & 0 & $?$ & $?$ & $?$ & $?$ & ( & $?$ & $?$ & $?$ & $?$ & ? & ? \\
\hline 24 & 0 & 0 & 0 & 0 & 0 & 1 & 0 & 1 & 0 & 0 & 1 & 1 & $?$ & $?$ & $?$ & ? & ? & $?$ & $?$ & ? & $?$ & ? & $?$ \\
\hline 25 & 1 & 1 & 0 & 1 & 0 & 1 & 1 & 1 & 1 & 1 & 1 & 1 & $?$ & $?$ & $?$ & ? & ? & ? & ? & ? & $?$ & ? & $?$ \\
\hline 26 & 0 & 0 & 0 & 0 & 0 & 0 & 0 & 1 & 0 & 0 & 1 & 0 & $?$ & $?$ & $?$ & $?$ & ? & $?$ & $?$ & $?$ & $?$ & $?$ & $?$ \\
\hline 27 & - & - & - & - & - & - & - & 0 & 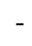 & & 1 & - & $?$ & $?$ & $?$ & ? & ? & ? & $?$ & $?$ & $?$ & ? & $?$ \\
\hline 28 & 1 & 1 & 1 & 1 & 1 & 1 & 1 & 0 & 1 & 1 & 1 & 1 & $?$ & $?$ & $?$ & $?$ & e. & ? & $?$ & $?$ & $?$ & $?$ & $?$ \\
\hline 29 & 1 & 0 & 0 & 0 & 0 & 0 & 0 & 0 & 0 & 0 & 0 & 0 & $?$ & $?$ & $?$ & $?$ & ? & ? & $?$ & $?$ & $?$ & $?$ & $?$ \\
\hline 30 & 1 & 0 & 0 & 0 & 0 & 0 & 0 & 1 & 1 & 1 & 1 & 1 & $?$ & ? & $?$ & ? & $?$ & $?$ & $?$ & $?$ & $?$ & ? & \\
\hline
\end{tabular}




\begin{tabular}{llllllllllllllllllllllllllllll}
\hline \hline 31 & 0 & 1 & 1 & 1 & 1 & 1 & 1 & 0 & 0 & 0 & 0 & 0 & $?$ & $?$ & $?$ & $?$ & $?$ & $?$ & $?$ & $?$ & $?$ & $?$ & $?$ \\
32 & 0 & 1 & 1 & 1 & 1 & 1 & 1 & 0 & 1 & 1 & 0 & 0 & $?$ & $?$ & $?$ & $?$ & $?$ & $?$ & $?$ & $?$ & $?$ & $?$ & $?$ \\
\hline
\end{tabular}

Gtr - G alipea trifoliata; Pmi - Pilocarpus microphyllus; Ppa - Pilocarpus pauciflorus; Psp - Pilocarpus spicatus; Pgi Pilocarpus giganteus; Pal - Pilocarpus alatus; Pja - Pilocarpus jaborandi; Ele - Esenbeckia leiocarpa; Rec - Raulinoa echinata; M fl - M etrodorea flavida; Hap - Helietta apiculata; Bri - Balfourodendron riedelianum; Pper - Pilocarpus peruvianus; Psu - Pilocarpus sulcatus; Ptri - Pilocarpus trifoliolatus; Pca - Pilocarpus carajaensis; Pde - Pilocarpus demerarae; Pgr - Pilocarpus grandiflorus; Ptra - Pilocarpus trachylophus; Ppen - Pilocarpus pennatifolius ; Pma Pilocarpus manuensis; Pra - Pilocarpus racemosus; Pri - Pilocarpus riedelianus; (?) - espécies que não foram analisadas neste trabalho, e que portanto, não se conhece o estado de caráter destes; (-) - não se aplica.

Após a construção da matriz (tabela 2), cada caráter foi mapeado utilizando a árvore filogenética proposta por Dias et al. (submetido). Neste trabalho, os autores incluíram como grupo externo seis representantes de gêneros relacionados a Pilocarpus, onde o enraizamento foi feito em Galipea, obtendo uma árvore baseada em caracteres morfológicos usando-se método bayesiano, onde Pilocarpus surge como grupo monofilético, e os demais representantes formam um grupo distal (Esenbeckia, Raulinoa, Metrodorea, Helietta e Balfourodendron).

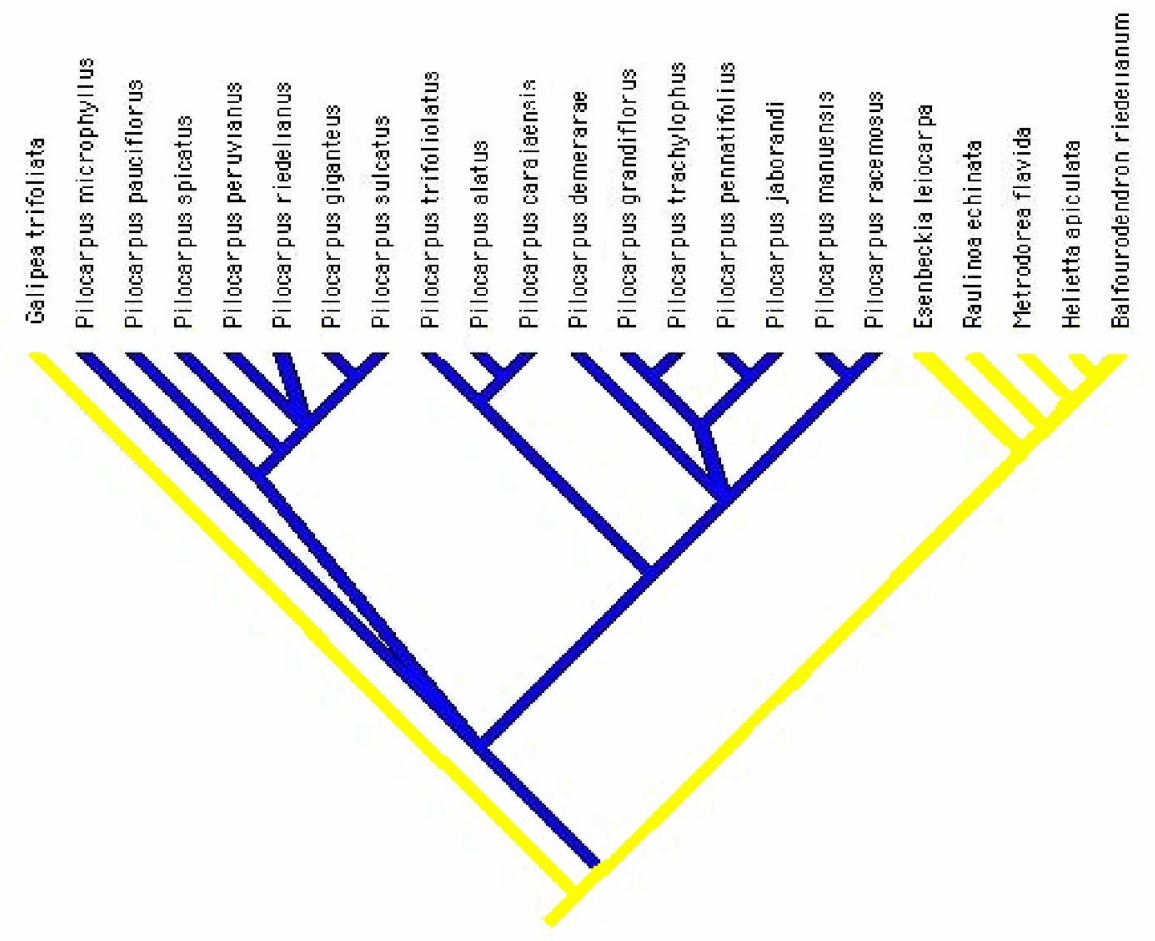

Fig.228. Filogenia de Pilocarpus (em azul) e gêneros relacionados (em amarelo) apresentada por Dias et al. (submetido) (modificado). 
O mapeamento forneceu 32 árvores, as quais foram agrupadas de acordo com o número de caracteres que alguns terminais apresentaram em comum, fornecendo os seguintes resultados (ver figuras 229-238):

Nas árvores mapeadas com os caracteres 4, 12, 14, 27 e 28, observa-se que E. leiocarpa, diverge dos demais terminais (Fig. 229 A-D).

O formato retangular das células do parênquima paliçádico (Fig. 230 A), ausência de cristais no parênquima paliçádico (Fig. 230 B) e presença de ráfides no pecíolo (Fig. 230 C) surgem uma única vez no grupo em G. trifoliata, separando-a do restante dos terminais. Adicionalmente, na árvore do caráter 4 (Fig. 230 D), G. trifoliata também é a única espécie que possui tricoma glandular capitado, com pedúnculo multicelular unisseriado e regial apical unicelular.

Além disso, o mapeamento dos caracteres 6 e 7 mostram árvores muito semelhantes (Fig. 231 A-B). Em ambos os cladogramas, o estado referente a parede sinuosa das células epidérmicas surge poucas vezes, além de estar presente nas espécies de G. trifoliata e M. flavida. A única diferença destes dois cladogramas é que no caráter 6 (Fig. 231 A), o estado parede sinuosa também surge em pelo menos duas espécies de Pilocarpus, embora apareçam neste grupo dois terminais que se desconhece o estado (equívoco). Outra observação é que, no grupo distal (Esenbeckia, Raulinoa, Metrodorea, Helietta e Balfourodendron), em ambas as árvores, a espécie M . flavida diverge dos demais gêneros por apresentar paredes sinuosas.

Ainda em relação ao grupo distal, nota-se que R. echinata e H. apiculata são os dois representantes que divergem deste grupo por apresentarem os seguintes estados: células da epiderme foliar face adaxial > abaxial (Fig. 232 A), nervuras terciárias aleatoriamente reticulada (Fig. 232 B), nervuras quaternárias dicotomizada (Fig. 232 C) e aréolas incompletas (Fig. 232 D). Os estados referentes aos caracteres 9 (Fig. 232 A) e 21 (Fig. 232 C) surgem no mínimo em mais dois terminais dos cladogramas, mas não se pode afirmar a quantidade exata de terminais que esse estado surgiu, uma vez que algumas espécies do grupo de Pilocarpus possuem estados de caráter incertos (equívocos).

Já na árvore do caráter 22 (Fig. 232 D), o estado aréola incompleta separa $P$. microphyllus do grupo de Pilocarpus. Esta situação mencionada no caráter 22, também ocorre no mapeamento do caráter 8 (Fig. 232 F), onde o estado estômatos anomocíticos surge apenas em P. microphyllus. No entanto, nas árvores dos caracteres 15 (Fig. 232 E) e 20 (Fig. 232 B), P. microphyllus além de divergir do grupo de Pilocarpus, é o único terminal que apresenta os estados sistema vascular aberto e nervura terciária dicotomizada. 
A ausência do tricoma tector na lâmina foliar (Fig. 233 A) mostra que R. echinata diverge dos demais representantes. No mapeamento de outros caracteres como ornamentação cuticular na lâmina foliar na face adaxial (Fig. 233 B) e tipo de estômato (Fig. 233 C), R. echinata também diverge em relação ao clado formado pelo grupo distal. No entanto, no caráter 1 (Fig. 233 B), somente G. trifoliata apresenta o mesmo estado de R. echinata, enquanto que no caráter 8 (Fig. $233 \mathrm{C}$ ), quase todas as espécies de Pilocarpus, exceto $\mathrm{P}$. microphyllus, possuem o mesmo estado que Raulinoa.

Os estados, terminações simples das nervuras (Fig. 234 A), células pericíclicas parenquimáticas (Fig. 234 B) e tricomas glandulares capitados na lâmina foliar, com pedúnculo e região apical unicelulares, (Fig. 234 C), surgem em dois representantes (H elietta e Balfourodendron) que pertencem ao grupo distal. Adicionalmente, o periciclo constituído por células parenquimáticas (Fig. 234 B), aparece só mais uma vez em Galipea, enquanto que as terminações simples das nervuras (Fig. 234 B) surgem em mais da metade dos terminais da árvore.

As árvores mapeadas com os caracteres 24 (Fig. 235 A) e 26 (Fig. 235 B) são muito semelhantes, mostrando que H. apiculata e E. leiocarpa divergem em relação ao grupo distal, por apresentarem epiderme papilosa e tricoma glandular, ambos no pecíolo. Além disso, só uma espécie de Pilocarpus apresenta a epiderme papilosa. Outra observação é que H. apiculata é o único terminal que diverge das demais espécies por possuir mais de uma camada de parênquima paliçádico (Fig. 235 C) e tricoma glandular peltado no pecíolo (Fig. $235 \mathrm{D})$.

O mapeamento dos caracteres 14 (Fig. 236 A), 30 (Fig. 236 B) e 31 (Fig. 236 C) mostra que o clado formado por todas as espécies Pilocarpus diverge dos demais terminais por apresentarem drusas de oxalato de cálcio no parênquima paliçádico e no pecíolo, enquanto que a presença de cristais prismáticos tanto no parênquima paliçádico quanto no pecíolo é característico dos gêneros relacionados a Pilocarpus.

No clado formado por Esenbeckia, Raulinoa, Metrodorea, Helietta e Balfourodendron, os caracteres 2 (Fig. 237 A) e 19 (Fig. 237 B) apresentam os terminais Raulinoa e Balfourodendron divergindo. No entanto, no mapeamento do caráter 2, uma espécie de Pilocarpus apresentou o mesmo estado que Raulinoa e Balfourodendron, enquanto que na árvore do caráter 19 (Fig. 237 B), os estados estão mais distribuídos entre os terminais. Além disso, a presença de domácia foi observada somente em Balfourodendron (Fig. 237 C). 
Quanto as árvores mapeadas com os caracteres 5 (Fig. 238 A), 17 (Fig. 238 B) e 25 (Fig. 238 C) não apresentam nenhuma relação com as demais árvores mapeadas. No caráter 5 (Fig. 238 A), observa-se que a distribuição dos estados (presente e ausente) está quase proporcional. No caráter 17 (Fig. 238 B), o cladograma formado pelas espécies de Esenbeckia, Raulinoa, Metrodorea, Helietta e Balfourodendron possuem os três estados relacionados ao ângulo das nervuras secundárias, embora o estado uniforme surge na maioria dos terminais. Com relação ao caráter 27 (Fig. 238 C), quase todas as espécies apresentam tricoma tector no pecíolo. Só duas espécies de Pilocarpus não possuem tal estado, e outras duas desse mesmo grupo, possuem incerteza neste caráter (equívoco).

\section{DISCUSSÃO}

\section{$\underline{\text { ANATOMIA }}$}

O gênero Pilocarpus Vahl vem sendo estudado desde o final do século XIX sob o ponto de vista taxonômico e principalmente anatômico, podendo-se citar trabalhos de Meyer (1892, apud Kaastra 1982), Duval (1903), Solereder (1908) e Metcalfe e Chalk (1950). Entretanto, de acordo com o levantamento bibliográfico realizado, o mesmo não ocorre para os demais gêneros presentes neste estudo, sendo poucos os trabalhos desenvolvidos.

Metcalfe \& Chalk (1979) realizaram uma ampla revisão sobre anatomia de Dicotiledôneas, abordando diferentes aspectos, dentre eles a ornamentação da cutícula. Neste trabalho, os autores descrevem que a ornamentação cuticular é um importante caráter diagnóstico para separar espécies, citando alguns exemplos em Anacardiaceae, Ericaceae e Sapotaceae. Em Rutaceae, Duval (1903) observou que esse caráter é freqüente para Pilocarpus. No entanto, dentre as espécies estudadas, o autor não menciona o tipo de ornamentação cuticular em P. microphyllus e P. spicatus. Já Spegazzini et al. (2002), mencionam a ocorrência da cutícula estriada, em ambas as faces da epiderme, para $P$. jaborandi e P. microphyllus, corroborando os resultados obtidos por Duval (1903) e Kaastra (1982) em relação à $P$. jaborandi. De acordo com os resultados obtidos neste trabalho, apenas Raulinoa echinata não apresentou cutícula estriada. Além disso, nem sempre as estrias são desenvolvidas de um mesmo modo nas duas faces da folha (Solereder 1908). Isso ocorre com P. pauciflorus e Balfourodendro riedelianum onde só a face abaxial é lisa; e em Galipea trifoliata onde a adaxial é lisa. Como exemplo de trabalhos que utilizam a ornamentação da 
cutícula na separação de espécies, cita-se o de Rocha \& Neves (2000) sobre anatomia foliar de duas espécies de Hibiscus (Malvaceae), sugerindo que tal caráter pode ser utilizado para separar H. tiliaceus (cutícula estriada) de H. pernambucensis (cutícula lisa). No presente estudo, este caráter não parece ser informativo na delimitação das espécies.

Quanto aos tricomas, Metcalfe \& Chalk (1950) citam que tectores e glandulares podem ocorrer em Rutaceae, embora este caráter não seja freqüente em muitos membros da família. Nas espécies estudadas, no presente trabalho, foi observado que pelo menos um, dos dois tipos registrados na família, ocorre na lâmina foliar. Com relação ao pecíolo, apenas duas espécies (Esenbeckia leiocarpa e Helietta apiculata) apresentam tricoma glandular, situação inversa no tipo tector onde $P$. pauciflorus e $P$. giganteus são as únicas que não apresentam esse tipo de tricoma. Em uma abordagem geral da distribuição dos tipos de tricomas, foi observada uma maior concentração de tricomas glandulares na lâmina foliar do que no pecíolo. Por exemplo, o tricoma glandular na folha ocorreu em todas as espécies estudadas, enquanto que no pecíolo, somente duas espécies apresentaram tal caráter.

Com relação aos tricomas tectores, o tipo unicelular foi evidenciado por vários autores para Pilocarpus (Duval 1903; Kaastra 1982; Skorupa 1996; Gallardo \& Jiménez 2002; Spegazzini et al. 2002). Neste trabalho somente R. echinata não apresentou tricomas tectores unicelulares, enquanto que nas demais espécies, este tricoma foi observado em ambas as faces da epiderme foliar.

Os tricomas secretores em Rutaceae são descritos por Kaastra (1982) como glândulas externas cuja região apical é globular multicelular. Para fins de terminologia, no presente estudo, foram considerados sinônimos tricomas glandulares e tricomas secretores. Além disso, Gallardo \& Jiménez (2002) também descrevem a presença de glândulas externas multicelulares na região abaxial de $P$. goudotianus (= P. racemosus subsp. Goudotianus). Entretanto, segundo Fahn (1974), o termo tricoma designa todos os apêndices unicelular e multicelular da epiderme. Portanto, observando a figura da glândula externa mencionada por Gallardo \& Jiménez (2002) e comparando-a com a terminologia de Fahn (1974) pode-se inferir que a glândula externa multicelular trata-se de um tricoma glandular multicelular.

Dentre as espécies analisadas, foram observados dois tipos de tricomas glandulares (capitado e peltado), ambos sendo multicelulares e ocorrendo nas faces adaxial e abaxial. Além disso, sete das doze espécies estudadas apresentam o tricoma capitado e somente $\mathrm{H}$. apiculata apresenta os dois tricomas na mesma lâmina foliar.

Quanto aos trabalhos com Pilocarpus, alguns autores (Duval 1903; Gallardo \& Jiménez 2002; Spegazzini et al. 2002) descreveram a ocorrência de tricomas glandulares em 
ambas as faces da epiderme, no entanto, não classificaram o tipo observado. Geiger (1897, apud Kaastra 1982) ressaltou que os tricomas glandulares estão presentes em todas as espécies de Pilocarpus, mas são raros em P. spicatus e P. microphyllus. Kaastra (1982) concorda com esta observação feita por Geiger (loc.cit) e acrescenta que estas espécies não possuem o tricoma em depressão, e que por este motivo freqüentemente estão quebrados. Já Spegazzini et al. (2002) mencionam a ocorrência dos tricomas em depressão bem como a região apical constituída por 2 células em P. microphyllus. No entanto, de acordo com os resultados obtidos neste trabalho para $P$. microphyllus, observa-se que estes tricomas são escassos e não ocorrem em depressão e que a região apical do tricoma é unicelular, e não multicelular como mencionado por Spegazzini et al. (loc.cit.).

Quanto ao número de camadas de células epidérmicas na folha, a epiderme é unisseriada, em ambas as faces, sendo observada para todos os indivíduos analisados, incluindo as espécies de Pilocarpus, corroborando os dados de Marquete (1981), Spegazzini et al. (2002) e Gallardo \& Jiménez (2002). O mesmo foi observado no pecíolo, semelhante ao descrito por Marquete (loc.cit.).

Segundo Metcalfe \& Chalk (1979), as paredes anticlinais das células epidérmicas podem ser retas, curvadas ou onduladas. Ao tratar das paredes anticlinais da epiderme em vista frontal, Duval (1903) observou que as espécies de Pilocarpus com folhas simples geralmente possuem paredes retilíneas e as de folhas compostas, paredes onduladas. Entretanto, o autor não mencionou se ambas as faces da epiderme possuem esta característica. Spegazzini et al. (2002) também descreveram tais características em três espécies de Pilocarpus com folhas compostas, observando que, em pelo menos umas das faces, possuem paredes retas a levemente onduladas. Neste trabalho, espécies de Pilocarpus, tanto de folhas simples quanto compostas, foram analisadas e verificou-se que na face abaxial, independente dos padrões foliares, todas as espécies possuem paredes retas. Além disso, na face adaxial, P. spicatus (folhas simples) apresentou paredes sinuosas. Portanto, com o aumento de espécies analisadas, percebe-se que a relação proposta por Duval (1903) não se aplica ao gênero Pilocarpus. Quanto aos resultados descritos por Spegazzini et al. (2002) a terminologia referente a parede "reta a levemente ondulada" é muito subjetiva. Além disso, comparando as fotos da epiderme em vista frontal das espécies mencionadas no trabalho de Spegazzini et al. (2002), com as analisadas neste estudo, observa-se que ambos os resultados foram iguais, sendo utilizados terminologias diferentes para a mesma característica. Ou seja, seguindo os parâmetros utilizados neste trabalho, as espécies P. jaborandi e P. microphyllus apresentam paredes retas e não "reta a levemente ondulada". 
Haberlandt (1928, apud Rocha \& Neves 2000) atribui à sinuosidade das paredes importante função mecânica, aumentando a rigidez da célula para prevenir o colapso parietal no caso de escassez de água. Esau (1985), em seu livro sobre anatomia vegetal, relata a ocorrência de células epidérmicas com paredes sinuosas como decorrência das condições ambientais como luz e umidade. Fahn \& Cutler (1992) estudaram as adaptações morfológicas e anatômicas em espécies que vivem em ambiente xérico, e constataram que geralmente as paredes anticlinais, em vista frontal, de algumas xerófitas são retas, entretanto em secção transversal estas podem ser muito sinuosas. Rocha \& Neves (2000) observaram que a parede anticlinal poderia ser usada como um caráter diagnóstico para separar duas espécies de H ibiscus (Malvaceae), uma vez que estas foram coletadas em um mesmo local, ou seja, sob as mesmas condições ambientais, entretanto, uma das espécies apresentava uma maior sinuosidade da parede. Com relação aos resultados obtidos no presente estudo, observou-se que todas as espécies coletadas na floresta ombrófila densa (Galipea trifoliata, Metrodorea flavida e Pilocarpus alatus), possuem pelo menos umas das faces da epiderme com paredes sinuosas em vista frontal. Assim, a colocação de Haberlandt (1928, apud Rocha \& Neves 2000) não pode ser considerada neste trabalho, já que na floresta ombrófila densa, provavelmente, não há escassez de água, além de não possuírem as características mencionadas por Fahn \& Cutler (1992) para xerófitas.

Quanto às colocações de Esau (1985) e Rocha \& Neves (2000), são mais interessantes para serem discutidas. Esau (1985) atribuiu à sinuosidade da parede em decorrência de fatores ambientais como umidade e luz. No presente estudo, foram coletadas três espécies da floresta ombrófila densa ( $G$. trifoliata, M. flavida e P. alatus) e uma espécie em mata de galeria ( $P$. spicatus), cujas possuem a sinuosidade da parede. Considerando que as condições ambientais desses dois perfis vegetacionais são parecidas, provavelmente, as taxas de umidades e de luminosidade sejam semelhantes. Deste modo, nota-se que tal caráter aparece em espécies, as quais estão submetidas a similares taxas de umidade e luz, corroborando a proposta de Esau (1985). No entanto, não foi possível comparar se duas espécies do mesmo gênero, sob as mesmas condições ambientais, apresentam alguma diferença nas paredes anticlinais, como Rocha \& Neves (2000) observaram com as espécies de Hibiscus, sendo, portanto, prematuro afirmar se este caráter é diagnóstico ou adaptativo para Pilocarpus e gêneros relacionados.

Outros caracteres ainda relacionado a epiderme são os tipos e a distribuição dos estômatos. Segundo Dickison (2000), a diversidade de tipos de estômatos oferece um dos mais importantes caracteres observados na epiderme. O autor ressalta que o tipo de estômato é usado como caráter chave na circunscrição do maior grupo de monocotiledônea. Fahn 
(1974) também menciona que a estrutura do complexo estomático pode ser utilizada em estudos taxonômicos. Além disso, Dickison (2000) acrescenta que a classificação dos tipos de estômatos desenvolvidos tem sido muito utilizada e que a maior parte dos grupos taxonômicos pode ser caracterizada por apresentarem um padrão, ou a combinação de dois ou mais padrões.

Adicionalmente, trabalhos com anatomia ecológica relacionam a posição dos estômatos dentre as células epidérmicas com as condições ambientais que a planta está submetida. Por exemplo, Fahn \& Cutler (1992) mencionam que estômatos em depressões ou criptas são característicos de xerófitas. Ainda segundo os autores, outras características como densidade estomática, presença de cutícula nas células-guarda e subsidiárias e, ocorrência de estômatos em ambas as faces da epiderme, também são utilizados como caracteres adaptativos.

De acordo com Metcalfe \& Chalk (1950), os estômatos, em Rutaceae, geralmente estão situados na face abaxial na maioria das espécies, e que as células subsidiárias aparecem com diferentes arranjos entre os membros da família. Neste estudo, todas as espécies de Pilocarpus e gêneros relacionados são hipostomáticas, com os estômatos ao mesmo nível das células epidérmicas, característica citada, para Pilocarpus, por vários autores como, Duval (1903), Marquete (1981), Spegazzini et al. (2002), Gallardo \& Jiménez (2002). Assim, confrotando os resultados acima, com a descrição sobre estômatos que Fahn \& Cutler (1992) fazem para xerófitas, pode-se inferir que tais espécies não apresentam características xeromórficas.

Quanto aos tipos de estômatos observados em Pilocarpus, Duval (1903) menciona a ocorrência de estômatos com 4-5 células subsidiárias sendo comuns nas espécies estudadas. Skorupa (1996) fez uma revisão taxonômica para este gênero e observou três tipos de estômatos: anomocítico (P. spicatus), tetracíticos comuns e estômatos com 4 células subsidiárias, sendo duas oblíquas na porção superior e duas na porção inferior. Além disso, o autor menciona a ocorrência de estômatos com 4-5 células subsidiárias sendo comuns nas espécies estudadas, corroborando as observações de Duval (1903). Estômatos tetracíticos também foram observados em P. goudotianus (= P. racemosus Vahl subsp. goudotianus Tul.) por Gallardo \& Jiménez (2002). Marquete (1981) observou estômatos do tipo anomocítico, anisocítico e tetracítico em P. organensis (= P. pauciflorus ). Já Spegazzini et al. (2002) mencionam a ocorrência de estômatos do tipo ciclocíticos em $P$. jaborandi, P. microphyllus e P. pennatifolius. Todas as espécies de Pilocarpus analisadas neste trabalho apresentaram predominantemente na lâmina foliar, estômatos tetracíticos, corroborando os dados de 
Skorupa (1996). Estômatos com 4-5 células subsidiárias também foram observados concordando com Duval (1903) e Skorupa (1996). Entretanto, Skorupa (1996) observou estômatos anomocíticos para P. spicatus, diferente com o que descrito para tal espécie no presente estudo. Para os gêneros relacionados, a maioria apresentou estômatos anomocíticos, exceto R. echinata, cujo o padrão foi o mesmo observado para Pilocarpus.

Neste presente estudo, além de terem sido analisados os tipos de tricomas, a ornamentação da cutícula, as paredes anticlinais da epiderme da folha e os tipos de estômatos, outras características relativas à epiderme também foram observadas. Uma delas é a relação do tamanho entre células epidérmicas, em secção transversal, da face adaxial x abaxial da lâmina foliar. A análise deste caráter é inédita para Pilocarpus, sendo que a maior parte das espécies analisadas apresenta as células da face adaxial e abaxial do mesmo tamanho. Possívelmente, este caráter não está relacionado ao ambiente, pois três espécies, que ocorrem no mesmo ambiente (floresta ombrófila), sob as mesmas condições de luminosidade, umidade e água, apresentaram características diferentes.

Outro registro importante para este estudo foi que, em secção transversal do mesofilo de Helietta apiculata, células epidérmicas de ambas as faces se dividem periclinalmente de forma irregular. Da literatura disponível até o momento sobre anatomia foliar de Rutaceae não foi registrada a ocorrência deste caráter na família. Situação semelhante é descrita para Asteraceae, onde Melo-de-Pinna et al. (em prep.), no estudo sobre anatomia foliar de xerófitas, verificaram que Eremathus sp. também apresentaram divisão periclinal de algumas células epidérmicas na face adaxial. É interessante observar, que ambas as espécies descritas acima, esta divisão periclinal da epiderme ocorre somente em algumas células, não podendo ser caracterizada como epiderme multisseriada. Diante disso, é difícil entender o porquê da epiderme possuir esta característica, uma vez que não há trabalhos feitos sobre tal caráter.

De acordo com Fahn (1974), em algumas folhas e pétalas, a parede periclinal externa das células epidérmicas é papilosa. Segundo Haberlandt (1918 apud Fahn 1974), estas estruturas têm a função de concentrar a luz nas plantas que crescem na sombra. Adicionalmente, Metcalfe \& Chalk (1979) mencionam que a epiderme papilosa é geralmente um caráter diagnóstico por sua localização ou pela aparência. Duval (1903) menciona a ocorrência de papilas na face abaxial em P. giganteus, P. pennatifolius e P. trachylophus. Metcalfe \& Chalk (1950) também registram estas células para alguns gêneros de Rutaceae, incluindo Pilocarpus. No entanto, na lâmina foliar, nenhuma das espécies analisadas, no presente estudo, apresentou esta característica. Já no pecíolo, a presença de epiderme papilosa em P. spicatus, Esenbeckia leiocarpa e H. apiculata foram observados, mas nenhum dos 
autores mencionados acima relata a ocorrência de papilas no pecíolo. Possivelmente, a definição funcional da epiderme papilosa, mencionada por Haberlandt (loc. cit.), não se aplicaria, nesta situação, para o pecíolo. É importante ressaltar que H. apiculata e E. leiocarpa são espécies cultivadas que foram coletadas na ESALQ (Escola Agrícola Luiz de Queiroz - Piracicaba/SP) e ambas não estavam num ambiente sombreado.

Quanto à presença de hipoderme, Metcalfe \& Chalk (1950) mencionam que alguns membros de Rutaceae, incluindo Pilocarpus podem apresentar uma ou mais camadas. Kaastra (1982), em sua monografia da flora neotropica, citou algumas espécies ( $P$. giganteus, P. jaborandi, P. racemosus e P. spicatus) onde alguns autores já haviam registrado tal característica. Entretanto, nenhuma espécie estudada neste trabalho apresentou hipoderme característica conforme descrição dos autores.

Alguns caracteres encontrados no mesofilo como: o número de camadas e a forma do parênquima paliçádico; presença de estruturas secretoras e idioblastos cristalíferos; também foram descritos no presente estudo.

A estrutura dorsiventral (bifacial) foi evidenciada em todas as espécies de Pilocarpus e gêneros relacionados corroborando os dados de Duval (1903), Marquete (1981), Guallardo \& Jiménez (2002) e Spegazzini et al. (2002). Além disso, somente Helietta apiculata apresentou parênquima paliçádico biestratificado, enquanto que nas demais espécies, é uniestratificado. Duval (1903) tentou relacionar o número de camadas com o padrão foliar (folha simples ou composta), ou seja, o parênquima paliçádico apresentou duas camadas nas espécies de folhas simples e uma ou duas camadas nas espécies de folhas compostas. Marquete (1981) e Spegazzini et al. (2002) analisaram apenas folhas compostas, descrevendo uma única camada de parênquima paliçádico, corroborando o padrão proposto por Duval (loc. cit.). Entretanto, este padrão não foi observado nas espécies estudadas, no presente trabalho, incluindo folhas simples e compostas de Pilocarpus, pois nas folhas simples foi descrita uma única camada de parênquima paliçádico, caráter que segundo Metcalfe \& Chalk (1950) é comum em Pilocarpus. Adicionalmente, Guallardo \& Jiménez (2002), mencionam que o parênquima paliçádico biestratificado é um caráter xeromórfico em $P$. goudotianus (= P. racemosus Vahl subsp. goudotianus Tul. ).

O formato das células do parênquima paliçádico em Galipea trifoliata, é retangular, enquanto que nas demais espécies, tende a ser mais cilíndrico (paliçada). Essa característica não foi registrada por nenhum dos autores acima mencionado. Sabe-se que o arranjo das células do parênquima paliçádico maximiza a eficiência da fotossíntese pelo posicionamento das células em um ótimo ângulo para a chegada dos raios solares (Dickison 2000). A espécie 
que possui tal característica foi coletada numa floresta ombrófila densa, onde, possivelmente a taxa de luminosidade é baixa. Entretanto, duas espécies (Pilocarpus alatus e Metrodorea flavida) que foram coletadas nesse tipo de vegetação não apresentam células do parênquima paliçádico retangular. Diante disso, seria interessante analisar outras espécies de Galipea, para tentar descobrir se este formato de célula está relacionado com alguma adaptação da planta ao ambiente ou se é um caráter diagnóstico.

Outra característica interessante referente ao parênquima paliçádico das espécies estudadas é a presença de cristais em “compartimentos”. A única espécie que não tem cristais nesta região é a mesma que apresentou o parênquima paliçádico com o formato retangular (Galipea trifoliata). No entanto, G. trifoliata possui ráfides no parênquima lacunoso e na região da nervura mediana. Além disso, todas as espécies de Pilocarpus apresentam drusas de oxalato de cálcio em "compartimentos" no parênquima paliçádico, enquanto que nas demais, são observados cristais em forma de bastonetes. Duval (1905 apud Kaastra 1982) foi um dos primeiros pesquisadores a observar a ocorrência de células septadas transversalmente com drusas de oxalato de cálcio em cada compartimento, como traço característico de quase todas as espécies de Pilocarpus. Esta característica também foi mencionada por Metcalfe \& Chalk (1950), Marquete (1981) e Spegazzini et al. (2002).

No entanto, o termo "células septadas" do parênquima paliçádico, mencionado por alguns autores citados acima, poderia ser melhor discutido. Por exemplo, a maioria das hifas dos fungos pode estar dividida por paredes transversais chamadas septos, onde tais hifas são ditas septadas. No caso dos fungos, os septos são perfurados por um poro central, ou seja, o protoplastos das células adjacentes está em continuidade com as células vizinhas (Raven et al. 2001). Esta descrição sobre septos para fungos é corroborada com a definição proposta por Font Quer (1979), onde septo seria uma estrutura constantemente perfurada, que divide incompletamente uma cavidade celular. Outro exemplo, mas agora em plantas vasculares, seria sobre a fibra septada. Segundo Esau (1974), as fibras podem desenvolver paredes transversais delgadas (septos) depois da formação das paredes secundárias, passando a ser denominadas de fibras septadas, ou seja, estes septos seriam paredes divisórias contínuas, sem a presença de um poro como nos fungos. Em relação ao termo septado, Hickey \& King (2000) o definem como dividido em compartimentos por paredes ou partições, corroborando a idéia para as fibras septadas. No caso destas divisões presentes no parênquima paliçádico descrito neste estudo, cada compartimento possui sua própria parede periclinal contínua, ou seja, não são perfuradas, como nos fungos, e nem delgadas, como nas fibras. Por esta razão, mesmo sabendo que a definição de septado proposta por Hickey \& King (2000) se aplicaria 
parcialmente na descrição das "células septadas" do parênquima paliçádico mencionado por Duval (1905 apud Kaastra 1982), nota-se que a definição ainda é vaga, pois não diz o número de paredes transversais que o septo pode possuir. Provavelmente, o septo seja formado por uma parede transversal delgada, como ocorre nas fibras septadas, situação essa que não se aplica ao parênquima paliçádico descrito no presente estudo, pois este possui duas paredes, como um possível resultado de divisão celular. Assim, a terminologia sugerida no presente trabalho foi "compartimento" do parênquima paliçádico ao invés do termo "células septadas" do parênquima paliçádico como mencionado por Duval (1905 apud Kaastra 1982) e outros autores. Ressalta-se a necessidade de um estudo ultraestrutural e ontogenético para que novas informações sejam geradas.

Quanto ao parênquima lacunoso, apresenta um número variado de camadas (5-13), no entanto, todas as espécies estudadas apresentam células braciformes, formando espaços intercelulares. Para Pilocarpus, Metcalfe \& Chalk (1950) e Marquete (1981) também mencionam a formação de grandes lacunas neste tecido, contudo, nenhum destes autores descreve o contorno das células como braciforme.

Ainda no mesofilo, todas as espécies do presente trabalho, apresentam alguma estrutura secretora (células e/ou cavidades). A característica mais marcante em Rutaceae é a presença de pontoações translúcidas nas folhas, que correspondem a cavidades glandulares multicelulares produtoras de óleos essenciais aromáticos, típicos da família (Solereder 1908 ; Metcalfe \& Chalk 1950, Cronquist 1981). A única espécie, deste trabalho, que não apresentou cavidades secretoras logo interno à epiderme foi Esenbeckia leiocarpa. Esta espécie possui somente células secretoras ao invés de cavidades, mas esta condição já foi mencionada por Metcalfe \& Chalk (1950), no qual as cavidades podem ser substituídas por células secretoras isoladas ou acompanhadas por tais células. Duval (1903) cita a ocorrência das cavidades secretoras no mesofilo das folhas, próximo à epiderme (cavidades subepidérmicas) em espécies de Pilocarpus. Tal situação foi descrita também por Kaastra (1982), para algumas espécies de Pilocarpus e M etrodorea e corrobora com os resultados apresentados aqui.

Segundo Esau (1974), as cavidades diferem das células secretoras pelo fato de serem resultados de dissolução de células (lisígena), de sua separação (esquizógena) ou de ambos os processos (esquizo-lisígena). Quanto à origem dessas cavidades em Rutaceae foram referidas como: esquizógena por Solereder (1908); lisígena ou esquizo-lisígena por Engler (1931); esquizógena ou lisígena por Metcalfe \& Chalk (1950). Observa-se que não há um consenso entre os autores acima mencionados sobre a origem das cavidades, uma vez que não há um padrão de desenvolvimento das cavidades entre as espécies de Rutaceae. A melhor forma de 
identificar a origem da cavidade de dada espécie é fazendo o estudo de desenvolvimento dessa estrutura. Por exemplo, o gênero Citrus sempre foi descrito possuindo cavidades secretoras lisígenas (Metcalfe \& Chalk 1950; Esau 1974). No entanto, no trabalho feito por Bennici \& Tani (2004), sobre a anatomia e ultraestrutura do desenvolvimento da cavidade secretora em Citrus sinensis e Citrus limon, eles observaram que estas espécies possuem cavidade de origem esquizo-lisígena. Para Pilocarpus, as cavidades secretoras seriam esquizógenas segundo os dados de Marquete (1981) e esquizo-lisígena para Spegazzini et al. (2002), definições sugeridas sem um estudo ontogenético. Com as espécies contidas no presente trabalho está sendo feito um estudo sobre desenvolvimento foliar (Muntoreanu \& Melo-de-Pinna, em prep.), e nos resultados preliminares foi possível observar que em Pilocarpus, e nos demais gêneros as cavidades são esquizo-lisígena.

$\mathrm{Na}$ nervura principal da folha, foram observados o contorno e a unidade vascular (sensu Menezes et al. 2003). Quanto ao contorno da nervura, este não foi utilizado como caráter. Por exemplo, em P. jaborandi, na base foliar o contorno é biconvexo, enquanto que no meio e no ápice é plano-convexo. Além disso, Duval (1903) descreveu o contorno de P. microphyllus como biconvexo, e no presente estudo, observou-se o padrão convexo-plano em toda a lâmina foliar. No entanto, alguns trabalhos utilizam este caráter (contorno da nervura principal) para delimitação taxonômica. Um exemplo, seria o trabalho de Bieras \& Sajo (2004), no estudo da anatomia foliar de espécies de Erythroxylum (Erythroxylaceae), onde os autores montaram uma chave de identificação dos referidos táxons utilizando este caráter. Porém, neste trabalho com Erythroxylum, os autores padronizaram a região analisada (mediana do limbo), comparando-a entre os táxons para a confecção da chave de identificação. Mas, para um trabalho com sentido mais filogenético, não seria viável utilizar um caráter que não possui um estado constante na região em que foi observado.

No pecíolo, o contorno e o tipo do sistema vascular não foram utilizados como caráter pelo mesmo motivo da folha acima discutido. Marquete (1981) estudou a anatomia do pecíolo de uma espécie de Pilocarpus, e descreveu que na região basal do pecíolo foram observados 3 feixes vasculares (um maior central e dois laterais menores) e que até a região apical, estes feixes se unem formando um só. Além disso, o autor menciona a ocorrência de numerosos idioblastos cristalíleros e presença de epiderme uniestratificada. Todos os dados descritos por Marquete (1981) corroboram o que foi observado para as espécies do presente estudo, talvez representando um padrão de desenvolvimento do sistema vascular no pecíolo. 
Segundo Geiger (1897 apud Kaastra 1982), unidade vascular da nervura mediana de Pilocarpus é colateral e circundada por um anel de esclerênquima, o que foi confirmado com as espécies estudadas, tendo essas células esclerenquimáticas origem pericíclica.

Domácias em cripta foram registradas em Balfourodendron riedelianum no presente estudo. O termo Domácia é, geralmente, aplicado a tufos de tricomas, depressões, bolsos ou sacos presentes nas axilas das nervuras de maior calibre, quando ocorrem exclusivamente na face inferior das folhas (Wilkinson 1979). Vários autores consideram que há uma relação restrita entre domácias e animais, principalmente ácaros e formigas. Solís (1997) estudou a anatomia de domácias foliares em três espécies de Rutaceae, registrando a ocorrência de domácias em cripta para a espécie de B. riedelianum.

Quanto aos estudos sobre arquitetura foliar, Hickey \& Wolfe (1975) demonstraram que as características da organização foliar são indicadores significativos para estudos taxonômicos e das relações filogenéticas dentro das dicotiledôneas. Por exemplo, Reis et al. (2004) estudaram a venação foliar de 22 espécies de Melastomataceae e concluíram que alguns caracteres desse estudo (tipo de aréola, tipo de venação última marginal, entre outras) podem ser úteis na delimitação de tribos e gêneros.

Dentre as espécies de Pilocarpus, o padrão de venação do tipo broquidódroma ocorre em todos os táxons (Skorupa 1996). O autor ainda menciona que P. giganteus e P. spicatus possuem uma tendência ao padrão eucamptódromo. Marquete (1981), também observou tal padrão para uma espécie de Pilocarpus. Neste trabalho, todas as espécies (Pilocarpus e demais gêneros) possuem padrão broquidódroma. Quanto as terminações de nervuras, Skorupa (loc. Cit.) menciona os tipos simples ou ramificados (1 ou 2 vezes), corroborando os dados do presente estudo. Em relação ao desenvolvimento das aréolas, os dados de Skorupa (loc. Cit.) mostram-se dos tipos incompletos e imperfeitos. Esta classificação também foi encontrada entre as espécies do presente estudo.

\section{MAPEAMENTO DOS CARACTERES}

A matriz morfológica do grupo Pilocarpus (e gêneros relacionados) ainda não está disponível na literatura, o que impossibilitou testar os caracteres, levantados neste trabalho, na filogenia do grupo. Diante disso, fez-se então uma análise preliminar destes caracteres, através do mapeamento utilizando o programa MacClade 4.0.

Nesta análise preliminar, não foi possível afirmar quais são os caracteres filogeneticamente informativos. Apesar disso, o mapeamento permitiu observar a tendência 
de alguns caracteres serem informativos para determinados terminais, ou até mesmo para o grupo Pilocarpus, propondo suas possíveis relações filogenéticas.

Nos resultados apresentados no presente estudo, as árvores mapeadas foram agrupadas de acordo com o número de caracteres que alguns terminais apresentaram em comum. Por exemplo, Raulinoa echinata e Helietta apiculata foram os terminais que apresentaram um maior número de caracteres em comum. No entanto, não é possível saber se alguns destes caracteres relacionados indicariam alguma sinapomorfia para estes representantes ou se seriam apenas caracteres homoplásticos.

Dos 32 caracteres mapeados, 8 possivelmente não sejam tão informativos se forem utilizados na análise cladística do grupo de Pilocarpus, uma vez que possam indicar autapomorfias. Dentre os terminais analisados, Esenbeckia leiocarpa foi o que apresentou um maior número de caracteres divergindo dos demais representantes (por exemplo, caracteres 4, 12, 18, 27e 28). Em Galipea trifoliata também foi observada tal situação.

Com relação às espécies de Pilocarpus, a presença de drusas de oxalato de cálcio no parênquima paliçádico (caráter 14) e no pecíolo (caráter 31) indica uma possível sinapomorfia para este grupo, podendo ser caracteres úteis para solucionar a tricotomia basal formada por $P$. microphyllus + o clado formado por $P$. pauciflorus + o clado formado por $P$. trifoliolatus, mostrada na filogenia proposta por Dias e colaboradores.

Ainda sobre a tricotomia formada no clado de Pilocarpus, alguns caracteres podem ser importantes para tentar resolver tal problema. Por exemplo, o caráter tipos de tricomas glandulares capitados na lâmina foliar (caráter 4) parece ser homoplástico e o estado pedúnculo unicelular com região apical unicelular tende a ser uma sinapomorfia para $P$. microphyllus e o clado formado por P. pauciflorus. Já o caráter tricomas glandulares peltados na lâmina foliar (caráter 5) também tende a ser homoplástico e o estado presente pode indicar uma sinapomorfia para o clado formado P. trifoliolatus a P. racemosus. 


\section{CONSIDERAÇÕES FINAIS}

O estudo morfo-anatômico foliar das espécies de Pilocarpus revelaram a presença de características comuns tais como:

- tricomas tectores unicelulares e tricomas glandulares na lâmina foliar;

- folhas hipostomáticas;

- cavidades secretoras subepidérmicas;

- mesofilo dorsiventral com 1 camada de parênquima paliçádico;

- drusas de oxalato de cálcio em "compartimentos" no parênquima paliçádico;

- unidade vascular central do tipo colateral;

- padrão de nervação foliar do tipo camptódromo-broquidódromo;

- presença de três cilindros vasculares livres na região basal do pecíolo, que se funde em um nível mais elevado.

Algumas das características acima mencionadas também foram observadas nas demais espécies dos gêneros relacionados à Pilocarpus. Além disso, tais características se mostraram importantes à caracterização geral das espécies.

Diante disso, pode-se concluir que os aspectos mais importantes abordados no presente estudo foram:

$\ddot{y}$ Contribuir com o conhecimento anatômico foliar de gêneros de Rutaceae neotropicais, trazendo dados inéditos para a literatura;

$\ddot{y}$ Identificar uma possível sinapomorfia para o grupo Pilocarpus, que seria a presença de drusas de oxalato de cálcio em "compartimentos" no parênquima paliçádico;

ÿ Sugerir a inclusão dos caracteres morfo-anatômicos foliares em novas análises cladísticas em Pilocarpus. 


\section{REFERÊNCIASBIBLIOGRÁFICAS}

Adobe Systens Incorporated. 2002. Photoshop 6.0. Todos os direitos reservados.

Aliscioni, S. S. 2002. Contribución a la filogenía del género Paspalum (Poaceae: Panicoideae: Paniceae). Ann. Missouri Bot. Gard. 89:504-523.

Bennici, A; Tani, C. 2004. Anatomical and ultra structural study of the secretory cavity development of Citrus sinensis and citrus limin: Evaluation of schizolysigenous ontogeny. Flora 199, 464-475.

Bieras, A. C.; Sajo, M.G. 2004. Anatomia foliar de Erythroxyllum P. Browne (Erythroxylaceae) do Cerrado do estado de São Paulo, Brasil; Acta Botanica Brasilica, v. 18 , n. 3, (601-612).

Bukatsch, F. 1972. Bemerkungen zur Doppelfärbung Astrablau-Safranin. Mikrokosmos, v. 61, n. 8 , p. 255.

Cronquist, A. 1981. An integrated system of classification of flowering plants. New York, Columbia University Press, 1981. 1262p.

Cronquist, A. 1988. The Evolution and Classification of Flowering Plants second edition. The New York Botanical Garden, New York. 555 pp.

Dahlgren, 1980. R.M.T., A revised system of classification of the angiosperms. Botanical Journal of the Linnean Society (London).

Dias, P., Udulutsch, R.G. \& Pirani, J.R. submetido. Phylogeny of Pilocarpus Vahl (Rutaceae) and stochastic mapping of characters. Syst. Biol.

Dickison, W.C. 2000. Integrative Plant Anatomy, Harcourt/Academic Press, San Diego.

Duval, A. 1903. "Les jaborandis". Bull. Sci. Pharm. 5: 41-109.

Engler A. 1874. Rutaceae. In: C. F. P. Martius \& A. G. Eichler. Flora brasiliensis. Vol. 12 (2). Munich.

Engler, A. 1986. Anacardiaceae: Anatomisches Verhalten. Leipzig: Die Natürlichen Pflanzenfamilien Bd. p. 139-140.

Engler, A. 1931. Rutaceae. In: Engler, A.; Prantil, K. Die Natürlichen Pflanzenfamilien. 2. ed. Leipizig.

Esau, K. 1974. Anatomia de plantas com sementes. São Paulo: Edgard Blücher.

Esau, K. 1985. Anatomía vegetal. $3^{\text {a }}$ ed. Omega, Barcelona. 
Fahn, A. 1974. Plant Anatomy. $2^{\text {nd }}$ ed. Pergamon Press, Oxford.

Fahn, A. \& Cutler, D. 1992. Xerophytes. Gebruder Borntraeger, Berlin.

Franklin, G. 1945. Preparation of thin sections of synthetic resins and wood - resin composites and a new macerating method for wood. Nature 155(39): 51.

Font Quer, P. 1979. Diccionário de Botanica. Madrid: Labor.

Gadek, P. A.; Fernando,E.S.; Quinn,C.J; Hoot, S.B; Terrazas, T.; Sheahan, M.C.; Chase, M.W. 1996. Sapindales: molecular delimitation and infraordinal groups. American Journal of Botany 83, pp. 802-811.

Gallardo, L.H. \& Jiménez, M.E. 2002. Anatomía foliar de Pilocarpus goudotianus Tul. (Rutaceae). Caldasia 24: 269-275.

Groppo Jr., M. 2004. Filogenia de Rutaceae e revisão taxonômica de Hortia Vand. (Rutaceae). Universidade de São Paulo, São Paulo. (Tese de Doutorado).

Heywood, V.H. 1993. Flowering plants of the world. B T Bastford Ltd. London.

Hickey, L. J. \& Wolfe, J. A. 1975. The bases of Angiosperm phylogeny: Vegetative morphology. Ann. Missouri Bot. Garden 62: 538-589.

Hickey, L. J. 1979. A revised classification of the architectureof dicotyledonous leaves. In: Metcalfe, C. R. \& Chalk, L 1950. Anatomy of the Dicotyledons. 2. ed. Oxford: Clarendon.p. 25-39.

Hickey M, King C. 2000. The Cambridge illustrated glossary of botanical terms.. Cambridge: Cambridge University Press. 208 pp.

Johansen, D. A. 1940. Plant microtechinique. McGraw - Hill Book Co. Inc., New York.

Judd, W. S., Campbell, C. S., Kellogg E. A., Stevens P. F. \& Donoghue M. J. 2002. Plant systematics: a Phylogenetic approach, 2nd ed. sinauer, Sunderland, Massachusetts, USA.

Kaastra, R.C. 1982. Pilocarpinae (Rutaceae). Flora Neotropica M onogaph 33. The New York Botanical Garden, New York.

Kraus, J.E., Sousa, H.C., Rezende, M.H., Castro, N.M., Vecchi, C. \& Luque, R. 1998. Astra blue and basic fucsin double staining of plant materials. Biotechnic \& Histochemistry 73: 235-243. 
Landrum, J.V. 2002. Four succulent families and 40 million years of evolution and adaptation to xeric environments: What can stem and leaf anatomical characters tell us about their phylogeny? Taxon, 51(3), 463-473.

Leaf Architecture Working Group (LAWG). 1999. Manual of leaf architecture morphological description and categorization of dicotyledonous and net-veined monocotyledonous angiosperms, Washington, DC, Smithsonian Institution.

Liu, W. \& Hu, Z. 1998. Comparative anatomy of secretory cavities in leaves of the Rutaceae in China. Acta Phytotaxon. Sinica. 36:117-127.

Maddison, W.P. \& Maddison, D.R. 2004. Mesquite: a modular system for evolutionary analysis, version1.05. (http://mesquiteproject.org).

Marquete, O. 1981. Anatomia e vascularização foliar e floral de Pilocarpus organensis Occhioni \& Rizzini (Rutaceae). Arq. J ard. Bot. Rio de J aneiro 25:117-159.

Mello-Silva, R. de .2005. Morphological analysis, phylogenies and classification in Velloziaceae. Botanical Journal of the Linnean Society 148: 157-173.

Menezes, N. L.; Silva, D. C. \& Melo-de-Pinna, G. F.2003. Folha. Pp. 301-325. In: B. Appezzato-da-Glória \& S. M. Carmello-Guerreiro (eds.). Anatomia vegetal. Editora UFV, Viçosa.

Metcalfe, C. \& Chalk, L. 1950. Anatomy of the Dicotyledons. v.II. Oxford, Claredon Press.

Metcalfe, C. \& Chalk, L. 1979. Anatomy of the Dicotyledons: leaves, stem and wood in relation to taxonomy with notes on economic uses. 2.ed. Oxford: Clarendon Press, v.1.

Ogundipe, O.T. 2002. Leaf anatomical studies on eleven species of Zanthoxylum Linn. (Rutaceae). Phytomorphology 52:103-112

Pirani, J.R. 1998. A revision of Helietta and Balfourodendron (Rutaceae, Pteleinae). Brittonia 50: $348-380$.

Pirani, J.R. 1999a. Estudos taxonômicos em Rutaceae: revisão de H elietta e Balfourodendron (Pteleinae), análise cladística de Pteleinae, sinopse de Rutaceae no Brasil. Universidade de São Paulo, São Paulo (Tese de Livre Docência).

Pirani, J.R. 1999b. Two new species of E senbeckia (Rutaceae, Pilocarpinae) from Brazil and Bolivia. Bot. J. Linn. Soc. 129: 305-313.

Pirani, J.R. 2002. Rutaceae. In Wanderley, M.G.L., Shepherd, G.J. \& Giulietti, A.M. (eds.) 
Flora Fanerogâmica do Estado de São Paulo. Vol. 2. HUCITEC/FAPESP, São Paulo, pp. 281-308.

Pirani, J.R. 2004. Three new species of Galipea (Rutaceae, Galipeinae) from Brazil. Bot. J . Linn. Soc. 144: 365-373.

Prance, G. T. 1972. Chrysobalanaceae. Flora Neotropica., vol. 9, p. 1-409.

Purvis, M.J., Collier, D.C. \& Walls, D. 1964. Laboratory techniques in botany. London, Butterwoths.

Radford, A.E.; Dickison, W.C.; Massey, J.R. \& Bell, C.R. 1974. Vascular Plants Systematics. New York, Harper \& How.

Raven, P. H.; Evert, R. F.; Eichhorn, S. E. 2001. Biologia vegetal. Rio de Janeiro: Ed. Guanabara Koogan,. 906p.

Reis, C.; Proença, S.L. \& Sajo, M.G. 2004. Vascularização foliar e anatomia do pecíolo de Melastomataceae do cerrado do Estado de São Paulo, Brasil. Acta Botanica Brasilica 18(4): 987-999.

Rocha, J. F. \& Neves, L. J. 2000. Anatomia foliar de Hibiscus tiliaceus e Hibiscus pernambucensis Arruda (Malvaceae). Rodriguésia 51(78/79): 113-132.

Ruzin, S.E. 1999. Plant microtechnique and microscopy. Oxford University Press, New York.

Scholz, H. 1964 Reihe Celastrales. In H. Melchior, A. Engler's Syllabus der Pflanzenfamilien mit besonderer Berücksichtigung der Nutzpflanzen nebst einer Übersicht über die Florenreiche und Florengebiete der Erde, 2: 289-299. Gebrüder Borntraeger, Berlin, Germany.

Skorupa, L.A. 1996. Revisão taxonômica de Pilocarpus Vahl (Rutaceae). Universidade de São Paulo, São Paulo (Tese de Doutorado).

Silveira, M. (1989). Preparação de amostras biológicas para Microscopia eletrônica de varredura. In: Manual sobre técnicas básicas em microscopia eletrônica. São Paulo: USP. V-1, p. 71-79.

Solederer, H. 1908. Systematic anatomy of dicotyledons. Clarendon, Oxford.

Solís, S. M. 1997. Estudios anatómicos de domacios foliares en tres especies de la familia Rutaceae. Bonplandia 9 (3-4): 295-303.

Soltis, D.E., Soltis, P.S., Chase, M.W., Mort, M.E., Albach, T.D., Zanis, M., Savolaninen, V., Hahn, W.H., Hoot, S.B., Fay, M.F., Axtell, M., Swensen, S.M., Prince, L.M., Kress, W.J., 
Nixon, K.C., and Farris, J.S. (2000). Angiosperm phylogeny inferred from 18S rDNA, rbcL, and atpB sequences. Botanical Journal of the Linnean Society, 133(4): 381-461.

Spegazzini, E.D; Castro, M. T.; Rossi, J; Carpano, S. M; Nájera, T. N. 2002. micrografía foliar cuali-cuantitativa de las especies de pilocarpus (rutaceae): p. jaborandi holmes, $\mathrm{p}$. microphyllus stapf exwardleworth y p. pennatifolius lem. Dominguesia 18 (1).

Strittmater, C. G. D. 1973. Nueva Técnica de Diafanización. Boletín de la SociedadArgentina de Botanica, Buenos Aires15(1):126-129.

Takhtajan, A.L. 1980. Outline of classification of flowering plants (Magnoliophyta). The Botanical Review 46(3): 1-271.

Takhtajan A. 1996. Diversity and classification of flowering plants. New York: Columbia University Press.

Wilkinson, H.P. 1979. The plant surface (mainly leaf). In Anatomy of the dicotyledons. Systematic anatomy of leaf and stem, with a breaf history of the subject (C.R.Metcalfe \& L. Chalk, eds.). Clarendon Press, Oxford, v.1, p.97-165 



Figuras 1-7. Especies representartes da farrilia Rutaceas 1-2. Filocarpus spicatus. 3. Filocarpus giganteus. 4. Galipea trifoliata. 5. Metrodorea flavida 6-7. Raumoa echimata. 

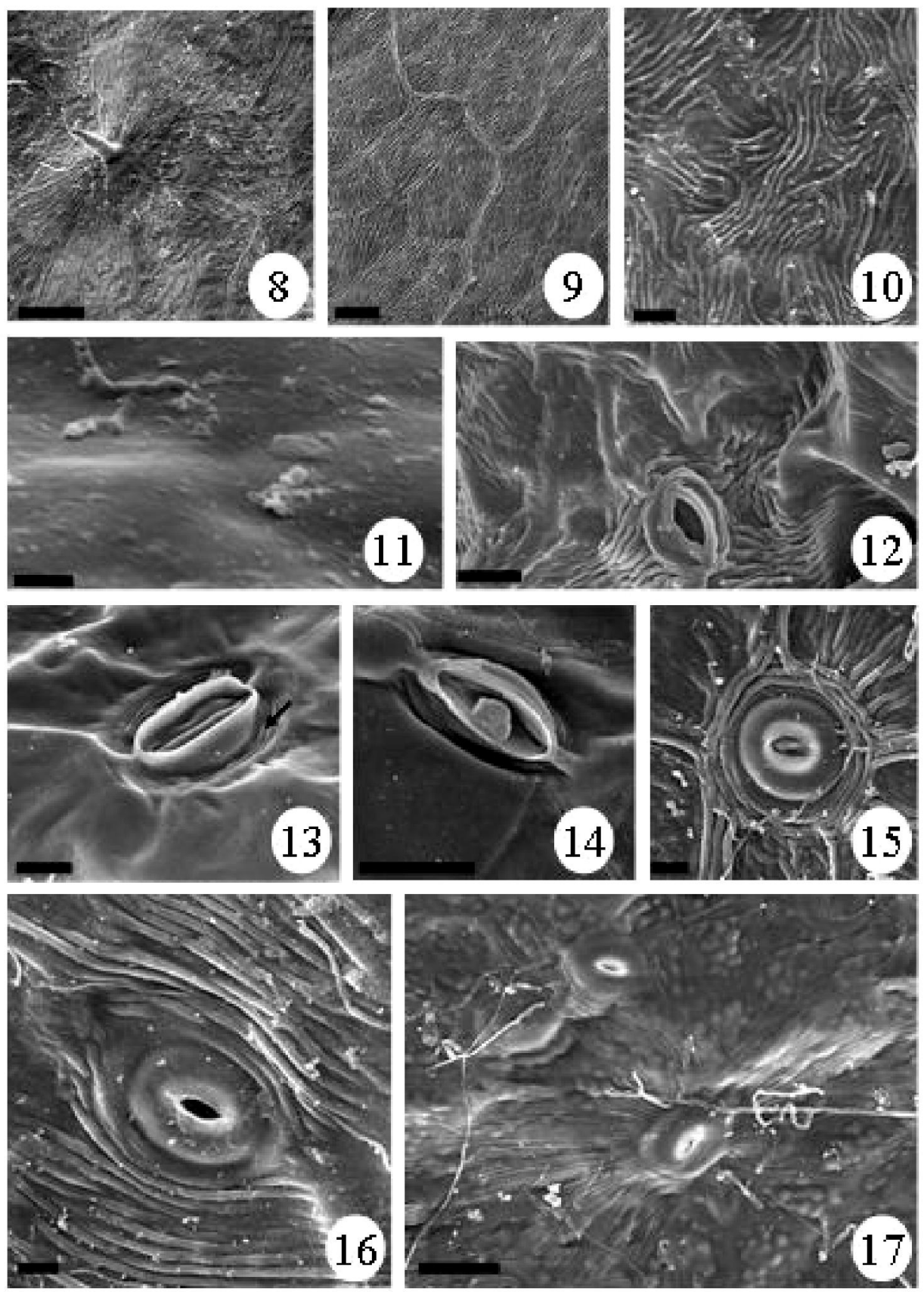

Figuras 8-17. Microscopia de varredura (MEW) da epiderme: detalhe da omamentapa as etriada da cuticula. Figuras 8-17: epiderne face adaxial. 8. Filocarpus microphylus 9. Filocarpus spicatus. 10. Metrodora flavida. 11. Raulino echinata: ausencia da cuticula estriada. Figuras 12-17: epideme face abaxial. 12. Esenbecha leiocarpa. 13-14. Galipea trifo liata preserpa e auseruia da cuticula estriada (seta), respectivartente. 15-16. Filocapus jaborandi: padróes diferentes das estrias ao redor do estômato. 17. Filocarpus microphilus: extersäo da cuticula estriada. Bama: $8-9,17=20 \mu \mathrm{m} ; 10,12-16=10 \mu \mathrm{mr} ; 11=5 \mu \mathrm{m}$. 

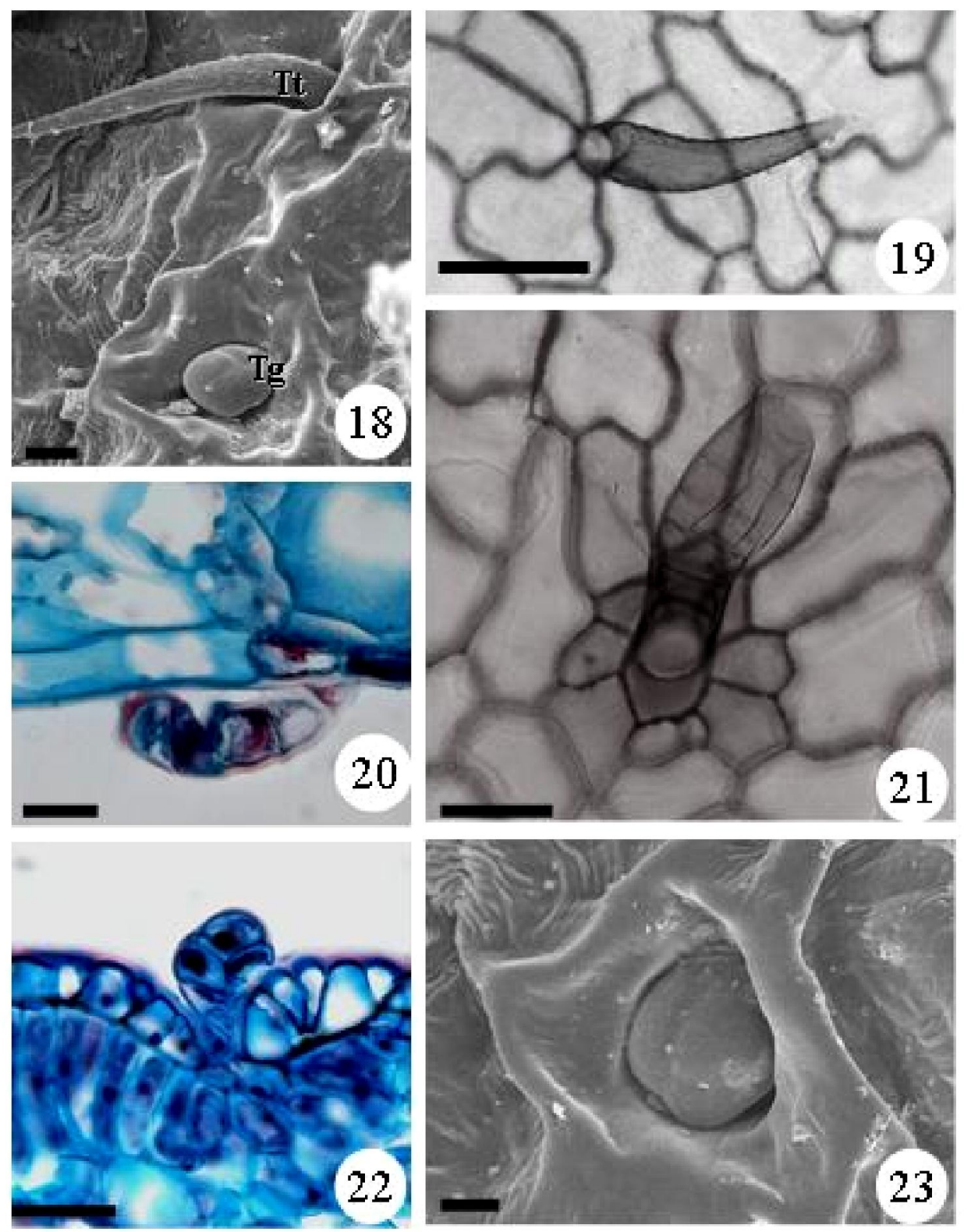

Figuras 18-23. Tipos de tricomas na folla. 18. Esenbecha leiocarpa: tricoma tector (Tt) filiforme e tricoma glandular capitado (Tg) em MEV. 19-21. Galipea trifoliata: tector (Fig. 19), glardular capitado em vista transwersal (Fig. 20) e frontal (Fig. 21). 22-23. Esenbecha leiocarpa: detalle do tricoma glardular capitado erm depressăo na epideme em secräa transwersal (Fig.2) e MEV (Fig. 23). Barras: $18=20 \mu \mathrm{m} ; 19=80 \mu \mathrm{m} ; 20-22=40 \mu \mathrm{m} ; 23=10 \mu \mathrm{m}$. 

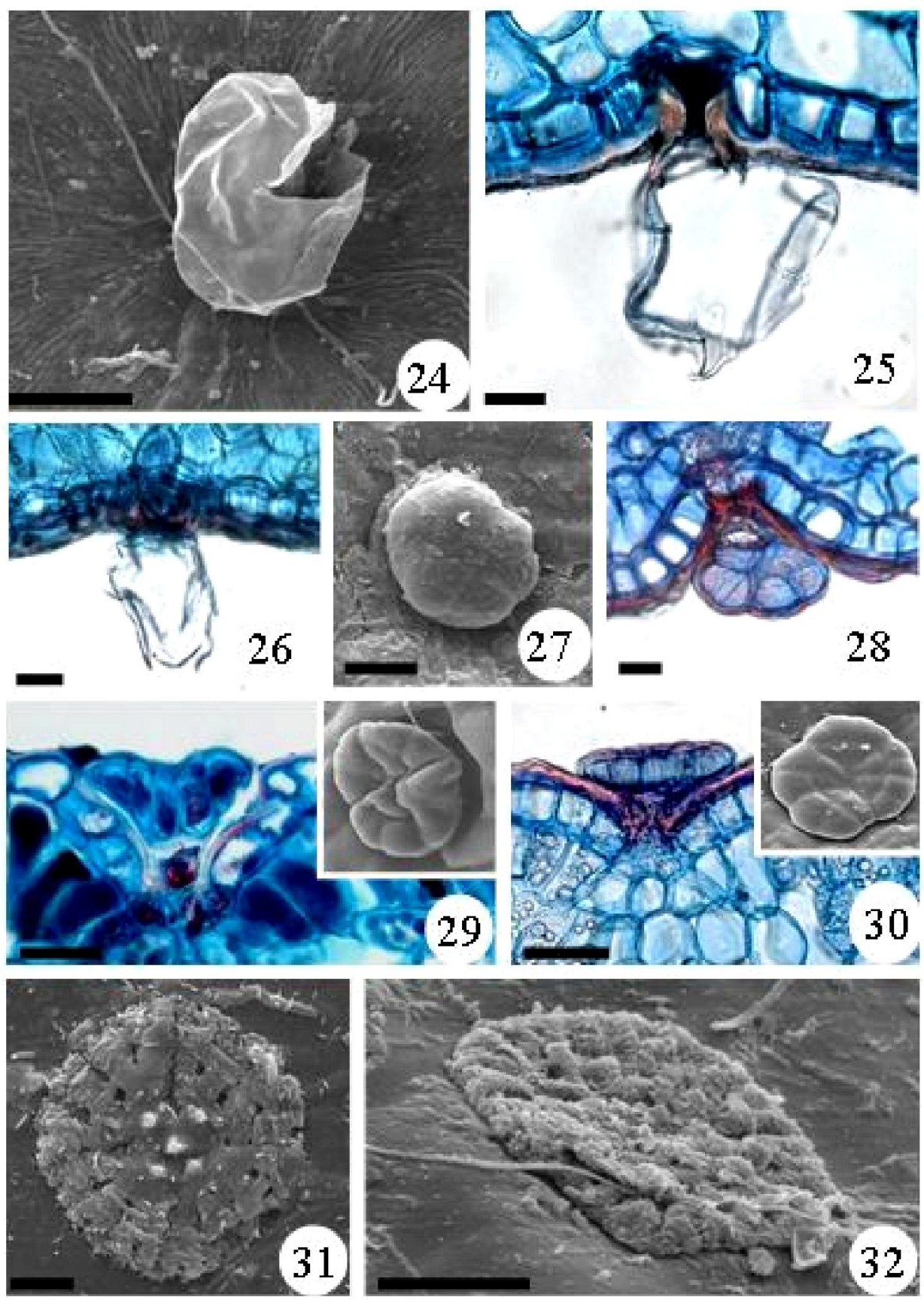

Figura 2432. Tricomas capitados e peltados. 24. Filocarpus spicatus: tricoma capitado, com célula apical urice lular em MEV 25-26. Filocarpus pauciforus e Filocarpus microphilus, respectramente: tricoma capitado, com celula apical urice lular em seç̧á trarwersal. 27-28. Balfourodendron riedelanum tricoma com célula apical multicelular en MEV (Fig. 27) e secça trarswersal (Fig. 28). 29. Metrodorea flavida: tricoma peltado era MEV (canto superior direito) e secpäo trareversal 30. Helietta apiculata: tricoma peltado err MEV (carto superior direito) e seçäo trarswersal 31-32. Raulinoa echinata em MEV Barras: $24,27-28=20 \mu \mathrm{m} ; 25-26,29,30=40 \mu \mathrm{m} ; 31-32=5 \mu \mathrm{mr}$. 
Generated by Foxit PDF Creator () Foxit Software

http://www.foxitsoftware.com For evaluation only.

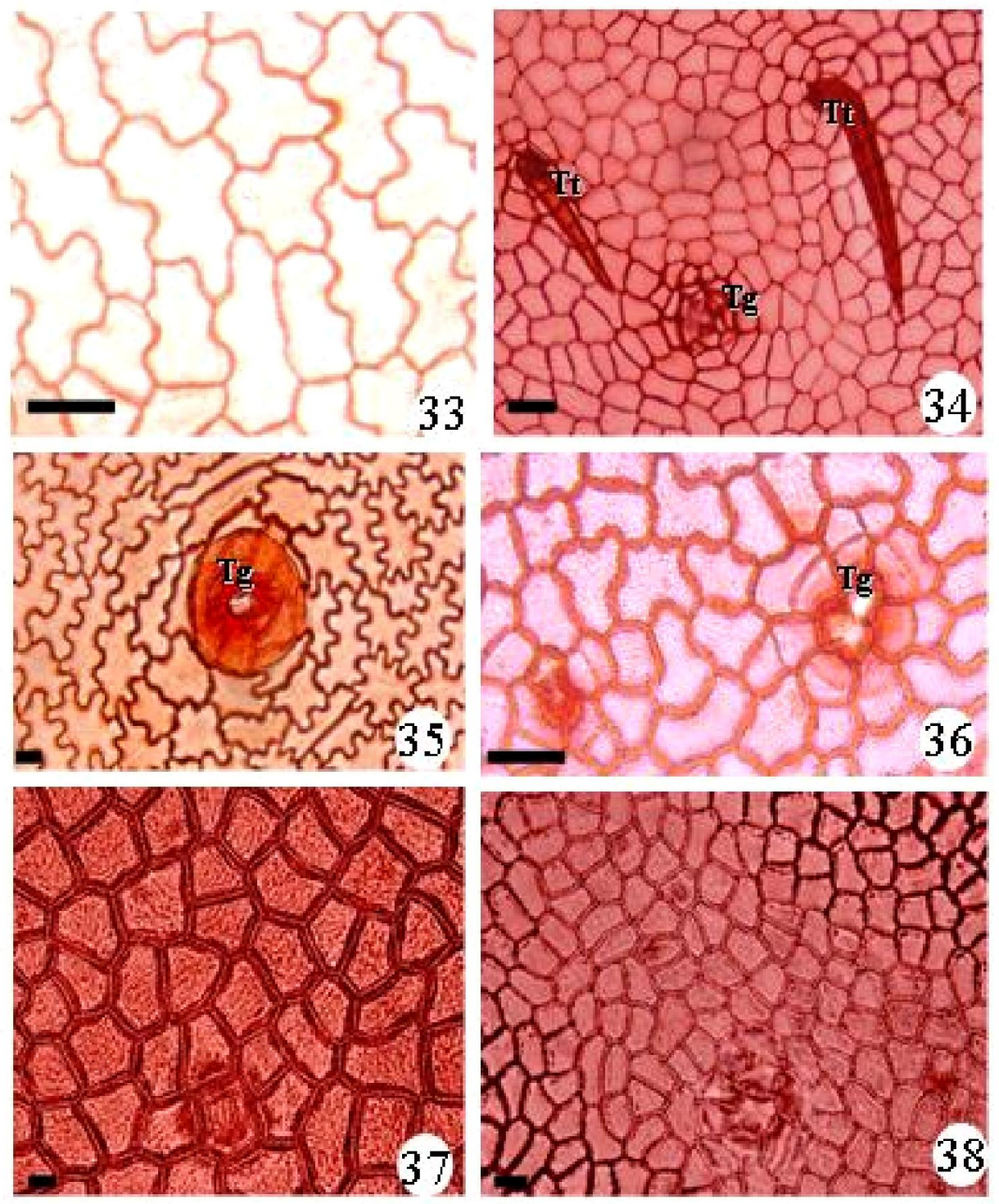

Figura 33-38. Wista frontal da face adaxal. 33.Galipea trifoliata. 34. Esenbecha leiocarpa. 35. Matrodorea flavida. 36. Filocarpus alatus. 37. Filocarpus jaborandi. 38. Filocarpus microphyllus. Tricoma tector (Tt) e tricoma glardular ( $\mathrm{Tg}$ ) Barras: $35-38=40 \mu \mathrm{m} ; 33-34=80 \mu \mathrm{m}$. 



Figurs 39-44. Vista frontal da face adaxial. 39. Pilocarpus pauciforus: tricoma glandular ( $\mathrm{Tg}$. 40 . Raulinoa echinata: cavidade subepidermica (seta) 41 . Helietta apiculata. 42. Balfourodendron riedelianum. 43. Pilocarpus giganteus: detalle do contomo das células da epiderrue em TEW ro carto superior direito. 44. Filocarpus spicatus. Banas: $39-41=80 \mu \mathrm{rr} ; 42-44=40 \mu \mathrm{ra}$. 

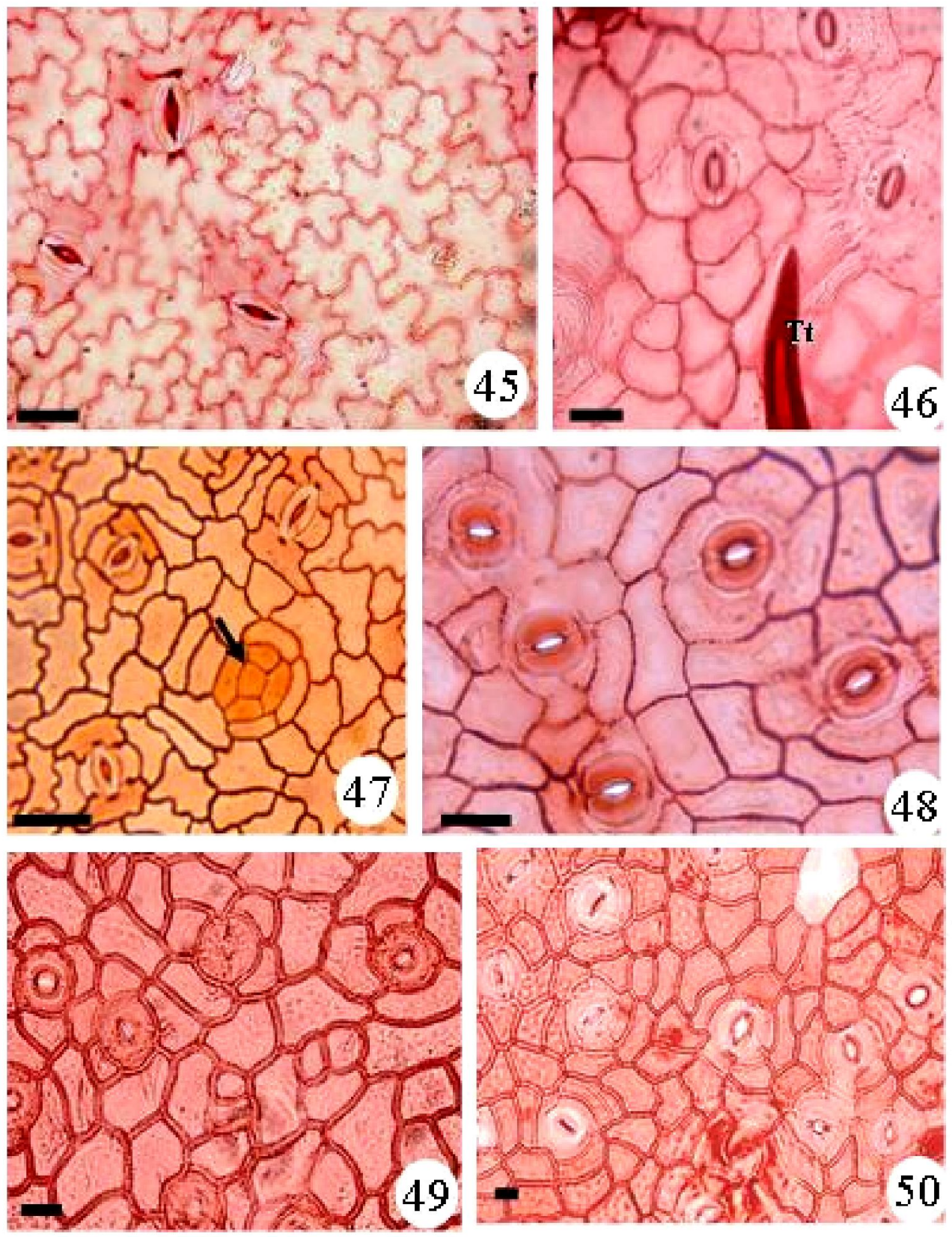

Figura 45-50. Tista frontal da face abaxial. 45. Galipea trifoliata. 46. Esenbecha leiocarpa. 47. Metrodorea flavida: detalhe da cavidade secretora subepidérmica (seta). 48. Filocarpus alatus. 49. Filocarpus jaborandi. 50. Pilocarpus microphyilus. Tricoma tector (Tt). Banas: $45-50=40 \mu \mathrm{m}$. 

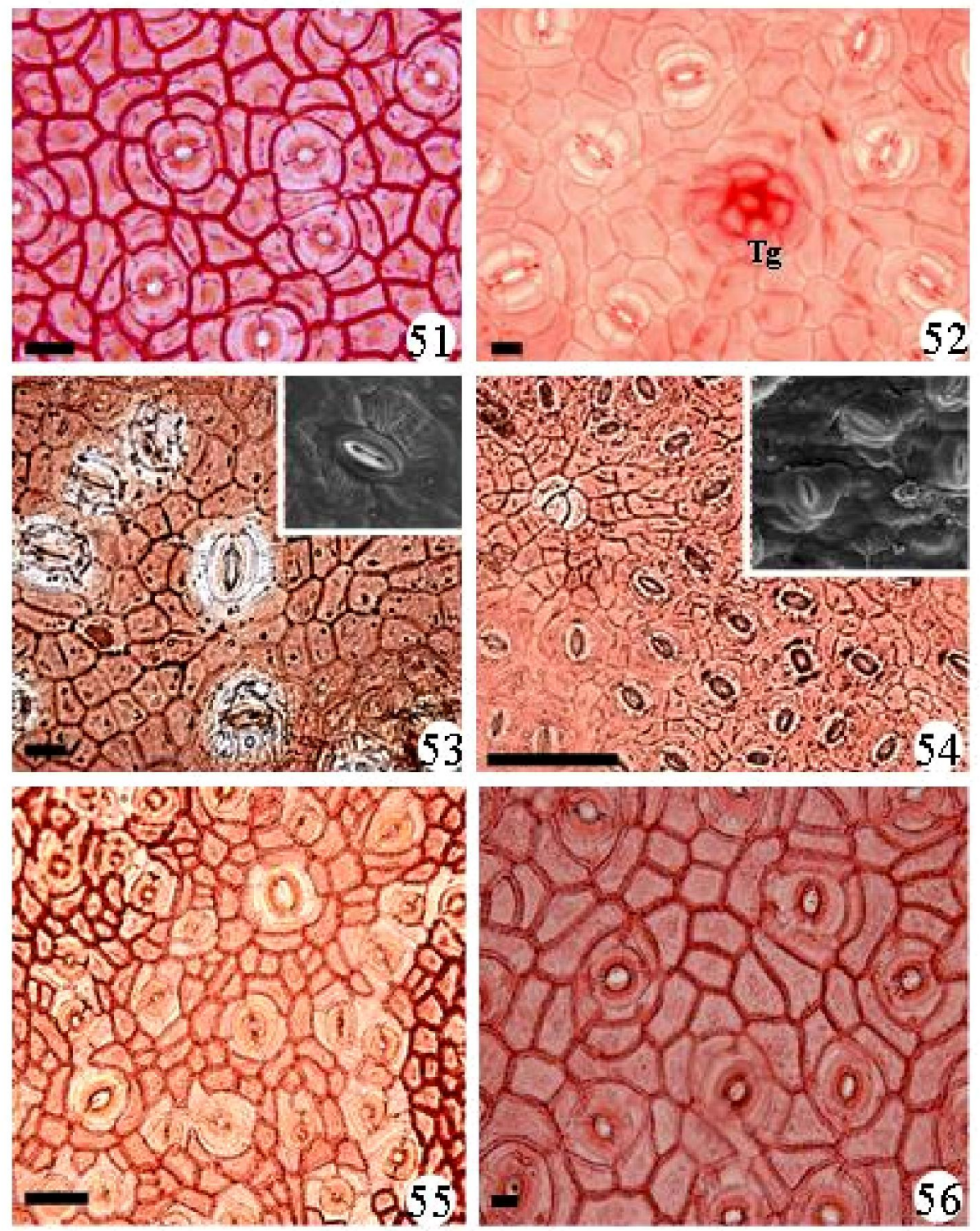

Figuras 51-56. Vista frontal da face abadial. 50. Fiborpus paucjlorus. 51. Raulinoa echinata: Tricoma glandular (Tg) 52 . Helietta apiculata: detalhe do estônato em MEW no canto superior dirito. 53. Balfourodendron riedelianum: notar estömatos em MEV no carto smerior direito. 54. Filocapus giganteus. 55. Filocarpus spicatus. Bamas: $51-53,55-56=40 \mu \mathrm{m} ; 54=160 \mu \mathrm{m}$. 

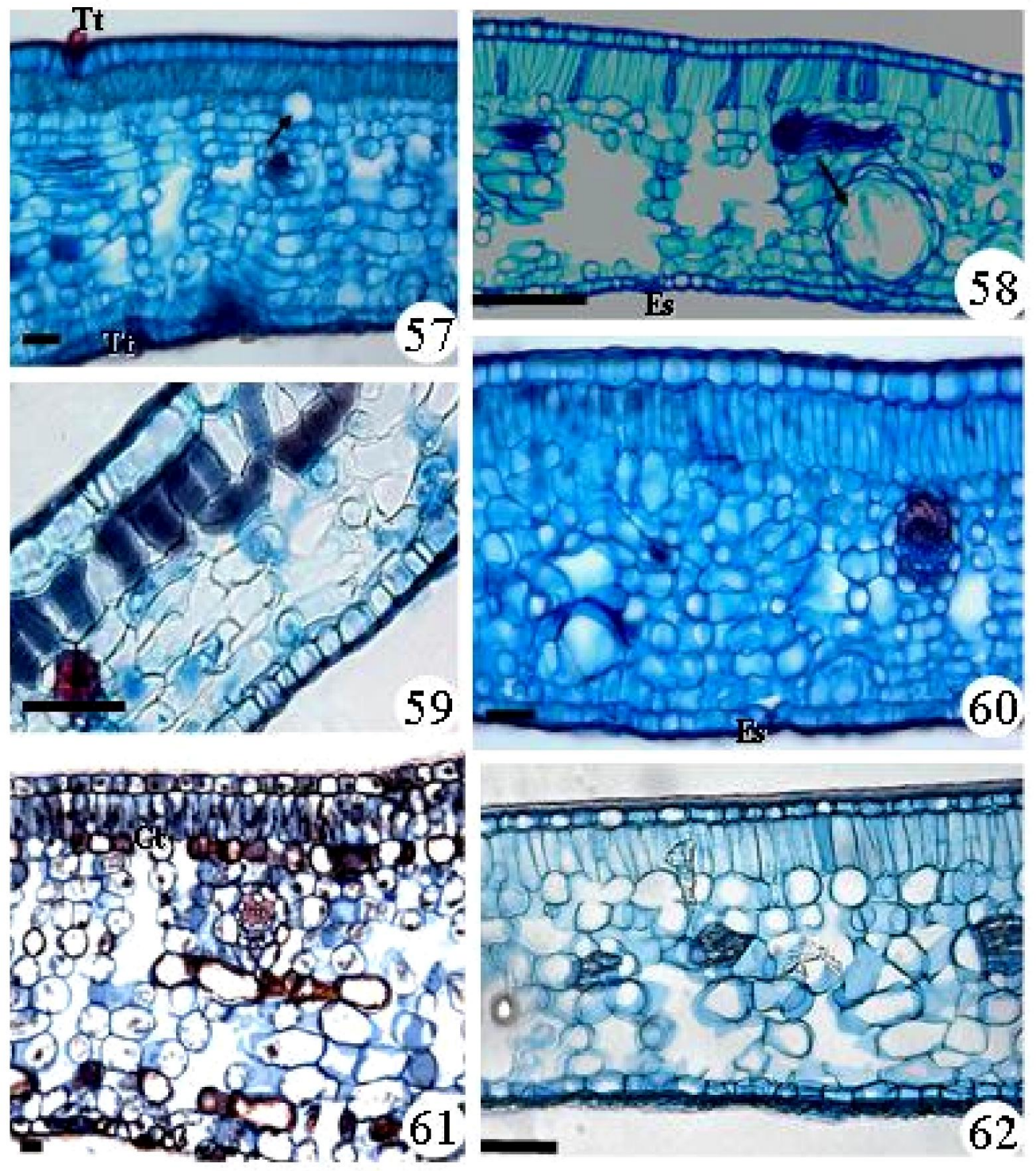

Figuras 57-62. Seçăo transwersal do mesofilo: Notar epiderme uriestratificada, mesofilo dorsiventral parênquima lacuroso braciforme, Celulas coletoras (Co), estômatos na face abaxial (Es) e estruturas secretoras (setas). 57. Esenbecha leiocarpa, onde se observa tricomas tectores em ambas as faces (Tt). 58 . Metrodorea flavida. 59. Galipea trifoliata. 60. Raulinoa echinata. 61. Filocarpus pauciforus. 62. Filocarpus microphylus. Barras: $57,60-62=80 \mu \mathrm{m} ; 58=160 \mu \mathrm{m}$; $59=40 \mu \mathrm{m}$. 

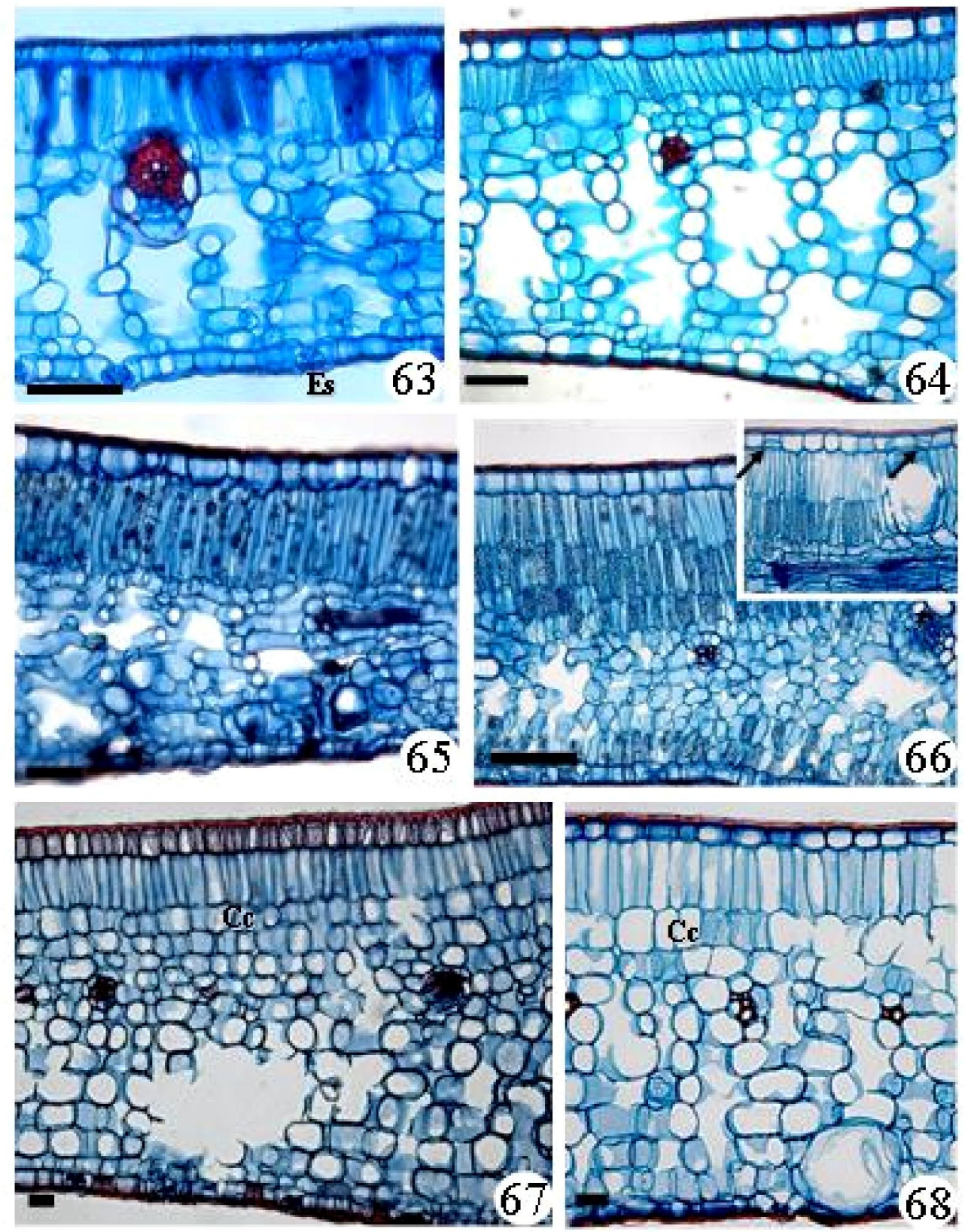

Figuras 63-68. Seção transersal do mesofilo: Notar epiderme uniestratificada mesofilo dorsiventral, parênquima lacuroso braciforme, Celulas coletoras (Co), estômatos na face abaxial (Es) e estruturas secretoras (setas). 63. Filocarpus alatus: estömato hipostomatico. 64. Filocarpus jaborandi. 65. Balfourodendron riedelianum. 66. Helietta apiculata: detalhe da epiderme se dividindo periclinalmente (seta) no canto superior dire ito. 67. Fibcarpus giganteus. 68 . Filocarpus spicatus. Barras: $63-65=80 \mu \mathrm{m} ; 66,68=2001 \mu ; 67=160 \mu \mathrm{m}$. 

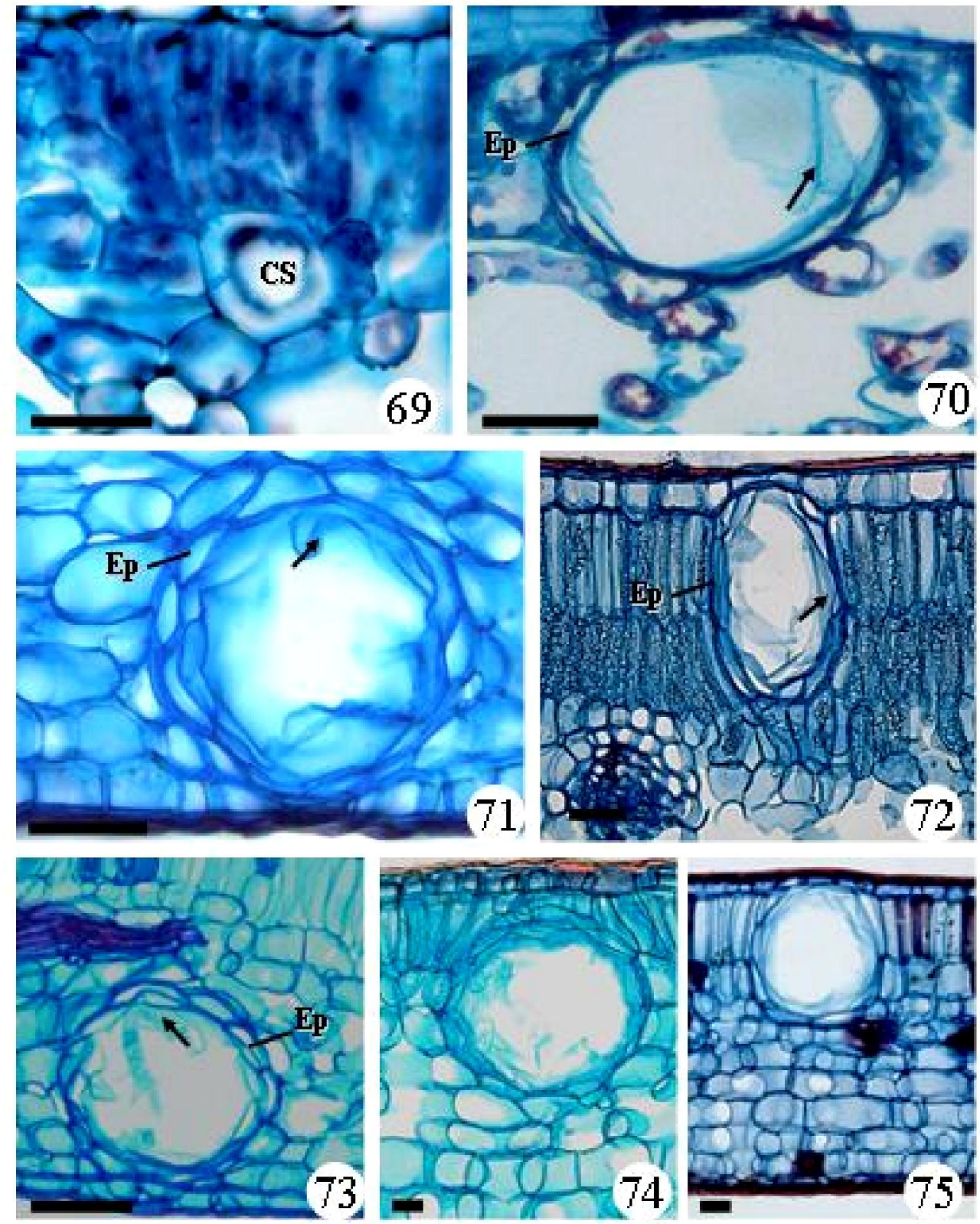

Figuras 69-75. Secräo trarsversal do mesofilo: Detalle da estrutura secretora. 69. Esenbeha leiocarpa: cellula secretora (CS). 70. Galipea trifoliata. 71. Faulinoa echinata. 72. Helietta apiculata. 73. Metrodorea flavida. 74. Pilocarpus paucjiforus. 75. Filocarpus spicatus. Farede de celulas lisadas (setas) e ocorrencia do epitélio da covidade secretora (Ep). Bamas: $69,72-73=40 \mu \mathrm{m} ; 70-71=80 \mu \mathrm{m}$; $73=160 \mu \mathrm{mr} ; 75=320 \mu \mathrm{m}$ 



Figuras 76-83. Secpăo longitudinal do ruesofilo: Detalhe da estrutura secretora. 76. Esenbecha leiocarpa: Celula secretora (CS). 77. Filocarpus jaborandi 78. Filocarpus paucjlorus. 79. Raulinoa echinata. 80. Galipea trjoliata. 81. Metrodorea flavida. 82 . Filocarpus alatus. 83. Fiboarpus microphylus. Farede de cellulas lisadas (setas) e epitélio da cavidade secretora (Ep). Barra: 76-79, 82-83 $=40 \mu \mathrm{m} ; 80-81=80 \mu \mathrm{m}$ 

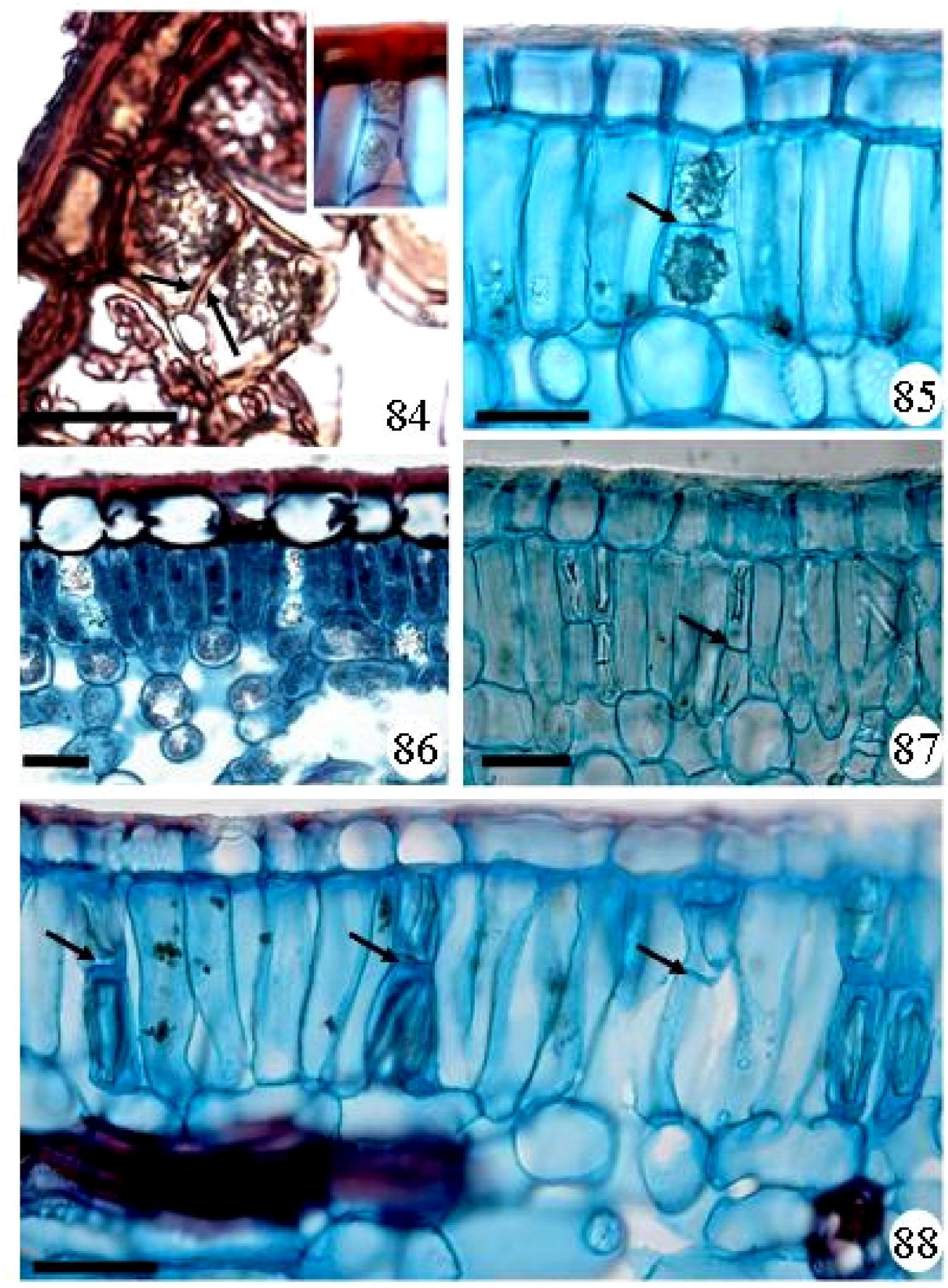

Figuras 8488. Secpäo longitudinal do mesofilo: Cristais. 8486. Drusas de oxalato de cálcio em compartimentos do parênquima paliçádico (setas) em Filocarpus alatus, Filocarpus paucjiorus e Filocarpus jaborandi, respectivamente. 87-88. Fresença de cristais com formato de bastonetes em compartimentos no parencuima paligadico (setas) em Esenbecha leiocarpa e Metrodorea flavida, respectivamente. Barras: $8488=40 \mu \mathrm{m}$. 

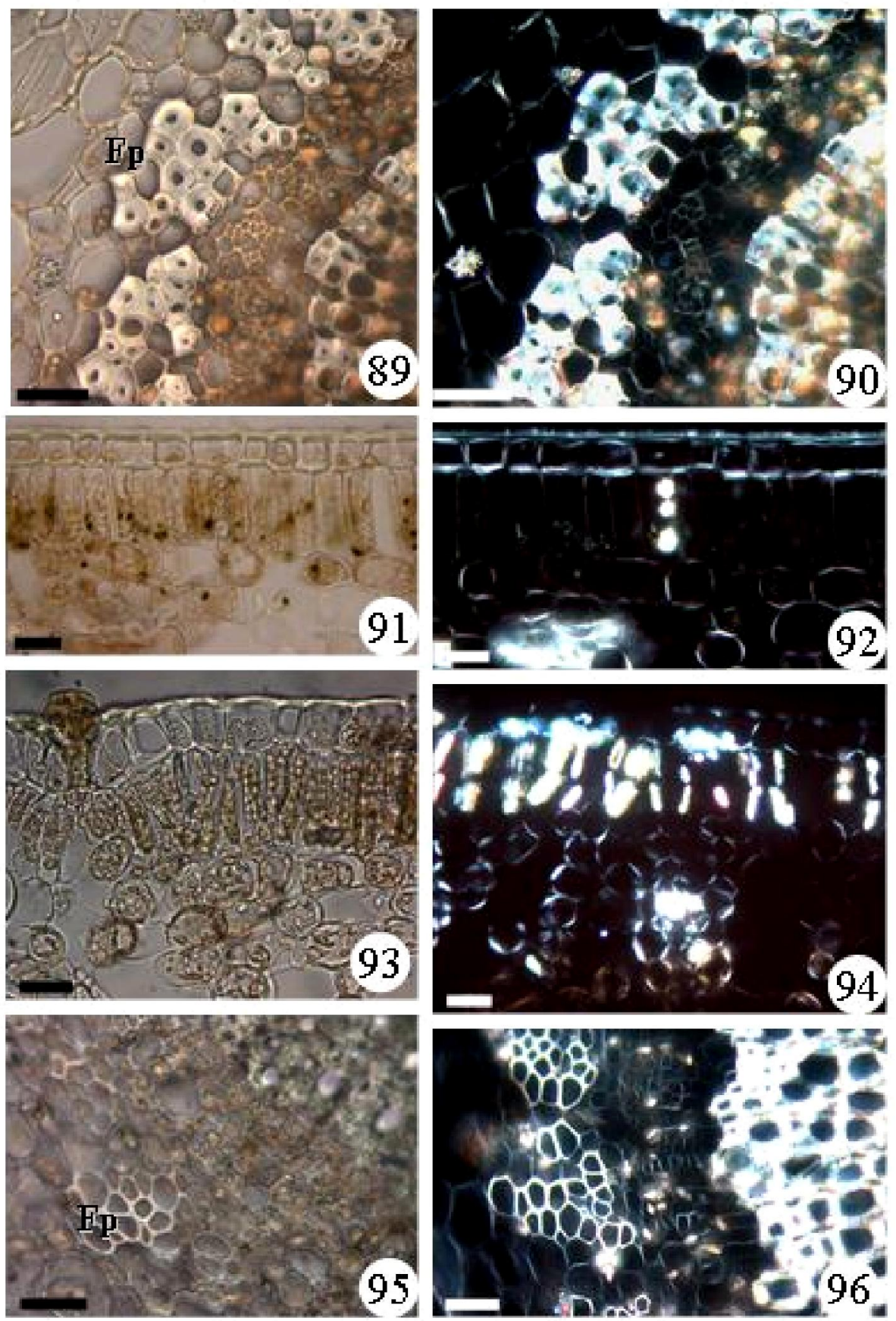

Figuas 89-96. Secróes trarwersais da larrima fo liar: columa da dire ita com lux polarizada e colura da esquerda sem luz polarizada. 89-90. Filocarpus alatus: drusas de oxalato de calcio proximo aos fibras periciclicas. 91-92. Pilocarpus pauciforus: drusas em compartirnentos do parenquima paligadico. 93-96. Esenbecha lajocarpa: cristais no parênquima palicadico (Figs. 93-94) e no floema (Figs. 95-96). Fibras periciclicas (Fp). Banas: 89-96 = 40 $\mu \mathrm{rr}$. 


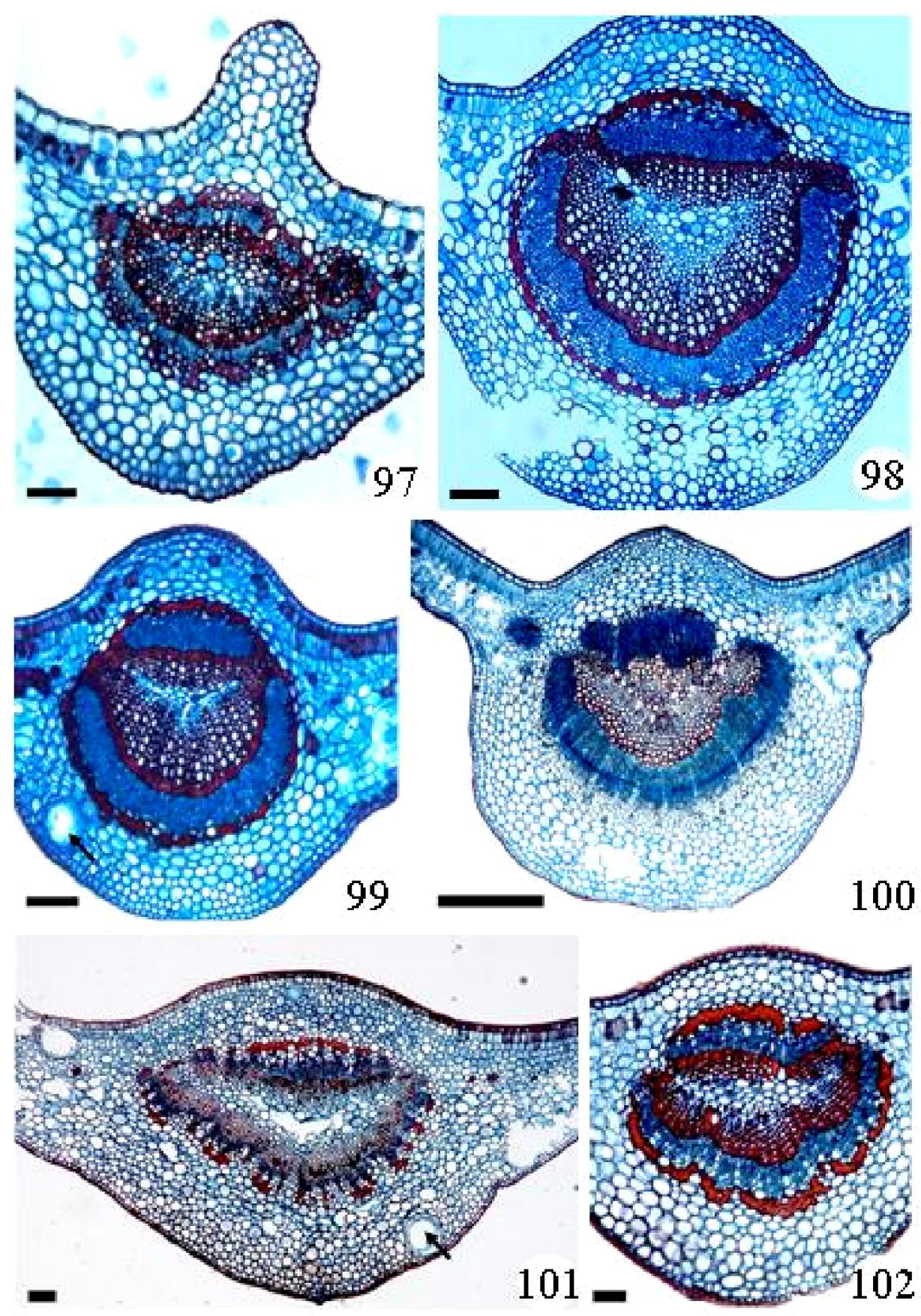

Figura 97-102. Seccăo trarswersal da lärima foliar: Fomato bicomexo da nervura mediara. 97. Galipea trifoliata. 98. Metrodorea flavida. 99. Filocarpus alatus. 100. Balfourodendron riedelianm. 101. Filocarpus giganteus. 102. Filocarpus spicatus. Notar as cavidades secretoras (setas). Barras: $97-99,102=160 \mu \mathrm{m} ; 100=620 \mu \mathrm{m}$; $101=320 \mu \mathrm{mr}$ 


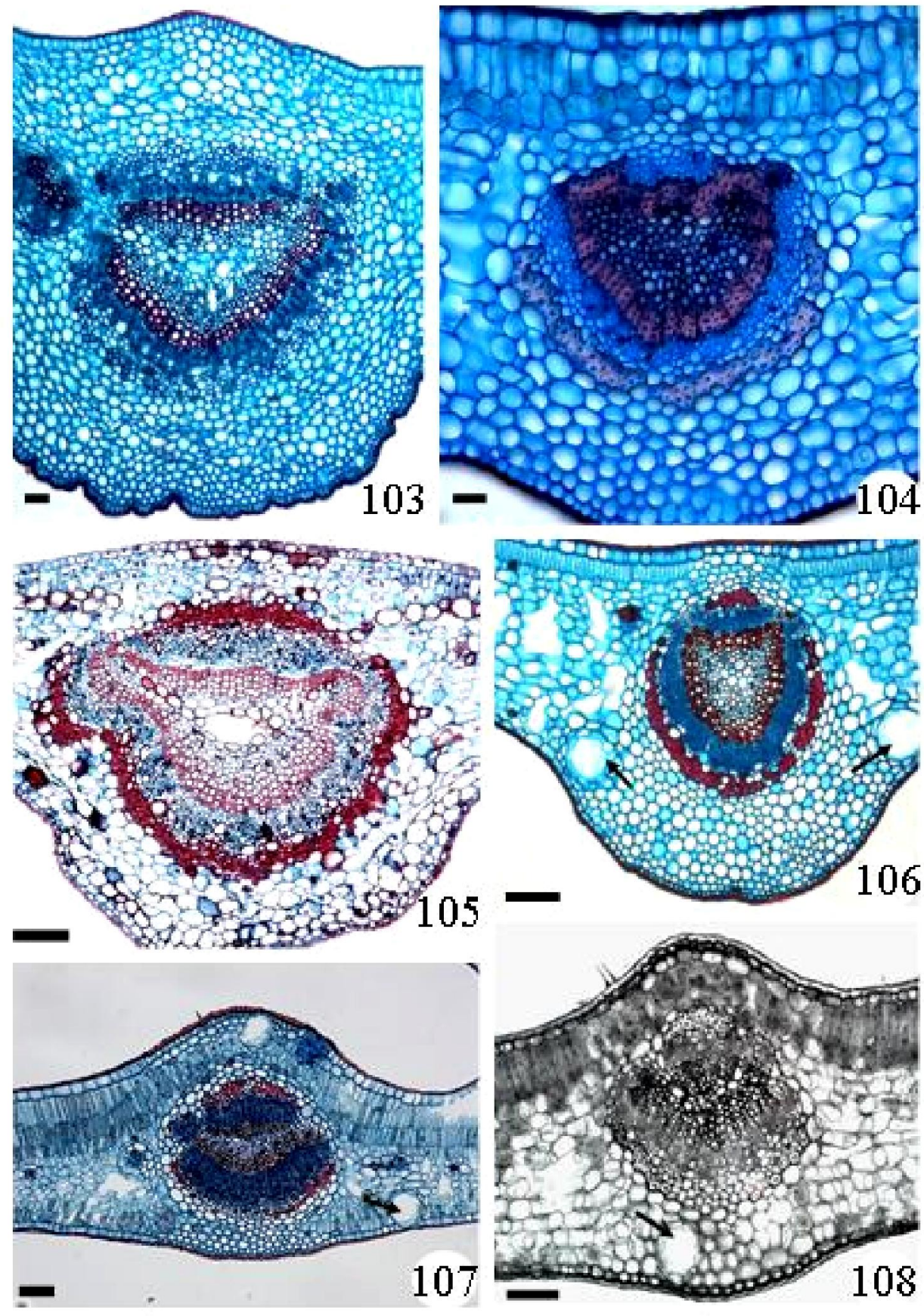

Figura 103-108. Secça trarbversal da lâruira foliar: Fonrato plano-convexo (Figs. 103-106) e convexo-plano (Figs. 106-107) da nervira mediana. 103. Esenbelia leiocarpa. 104. Raulinoa echinata. 105. Pilocarpus pauciflorus. 106. Filocarpus jaborandi. 107. Helietta apiculata. 108. Filocarpus microphylus. Cardades secretoras (setas). Barras: $103=320 \mu \mathrm{m} ; 104,108=80 \mu \mathrm{m} ; 105-107=$ $160 \mu \mathrm{m}$. 

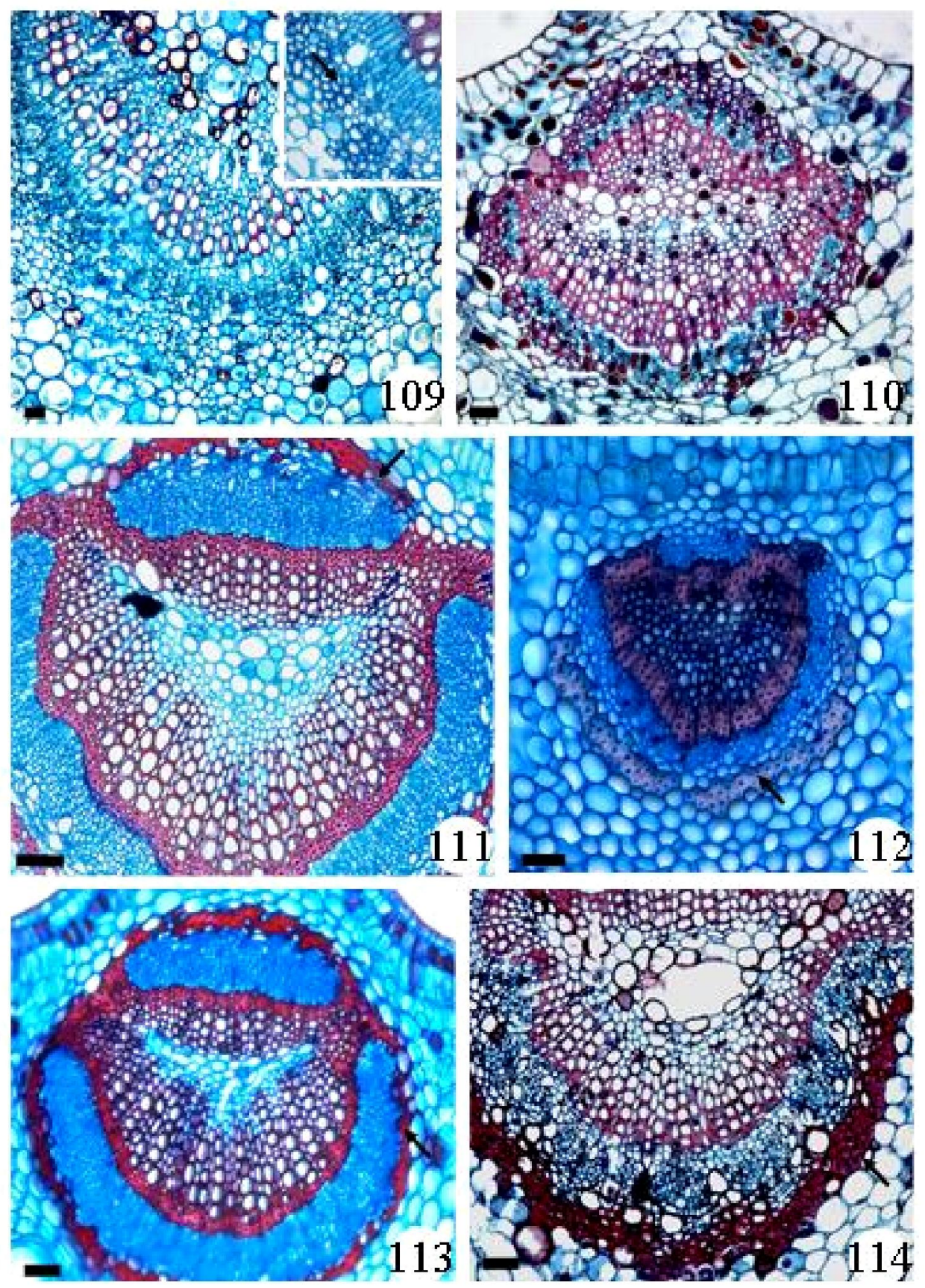

Figuras 109-114. Secça transwersal da nemura mediana: detalhe da uridade vacular. 109. Esenbecha leocarpa: detalle das fibra periciclicas (seta) diferenciadas na base da lâruira foliar no carto superior direito. 110. Galipea trifoliata. 111. Metrodorea flavida. 112. Ruulinoa echinata. 113. Filocarpus alatus. 114. Pilocarpus pauciforus. Fibras periciclicas (setas). Baras: $109-114=80 \mu \mathrm{m}$. 

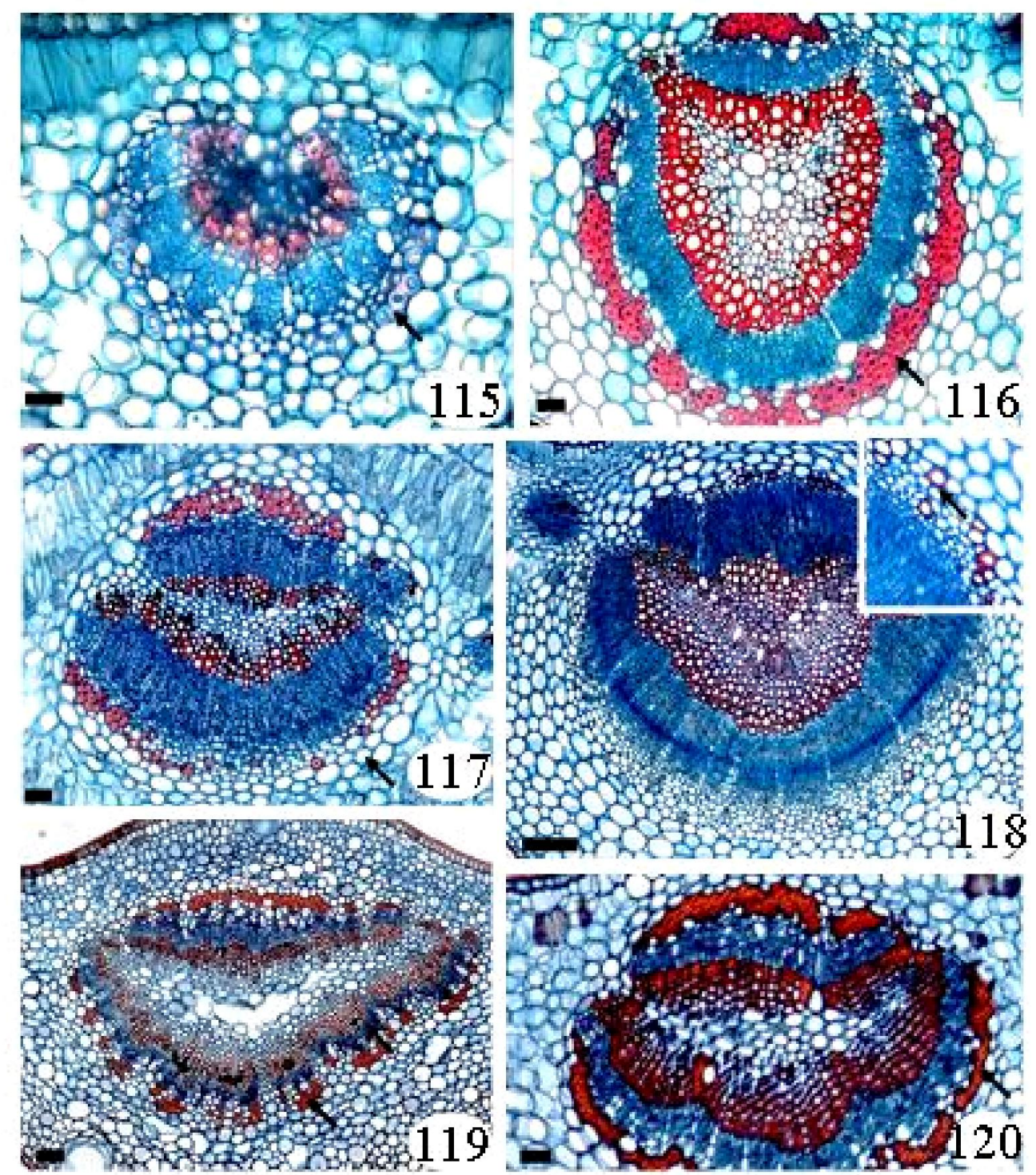

Figuras 115-120. Secpão transwersal da nervura mediana: detalhe da uridade vascular. 115. Pilocarpus microphylus. 116. Filocarpus jaborandi. 117. Helietta apiculata. 118. Balfourodendron riedelianum: detalle das fibrs periciclicas (seta) no canto superior direito. 119. Filocarpus giganteus. 120. Filocarpus spicatus. Fibras periciclicas (setas). Barras: $115-116=80 \mu \mathrm{m} ; 117-118,120=320 \mu \mathrm{m} ; 119=$ $640 \mu$ rit. 



Figuras 121-126. Donácia em Balfourodendron riedelianum. 121. localizaca da domacia em vista frontal. 122. Localizara a e camoterizaça da domácia em MEV: detalle dos tricomas tectores urice lular na abertura da cripta (seta). 123126. seça trarbversal da domacia: notar a fomaça da cripta aperas pela redurga do parenquima lacumoso. Tt- tricoma tector; $\mathrm{Wp}$ - nervura principal; $\mathrm{Wl}$ nemura lateral. Barras: $121,123-125=160 \mu \mathrm{m} ; 122=20 \mu \mathrm{m} ; 126=320 \mu \mathrm{rm}$. 

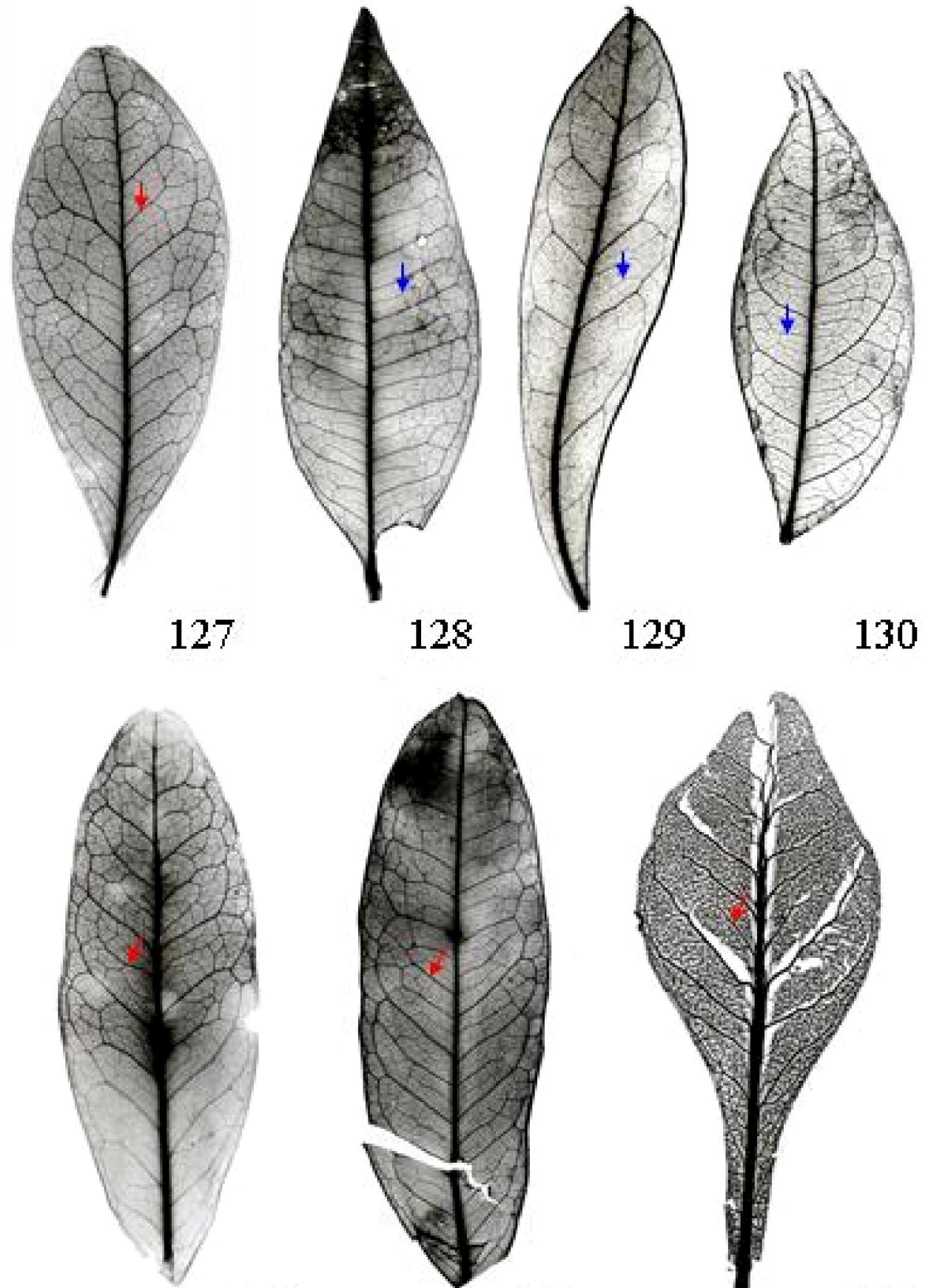

131
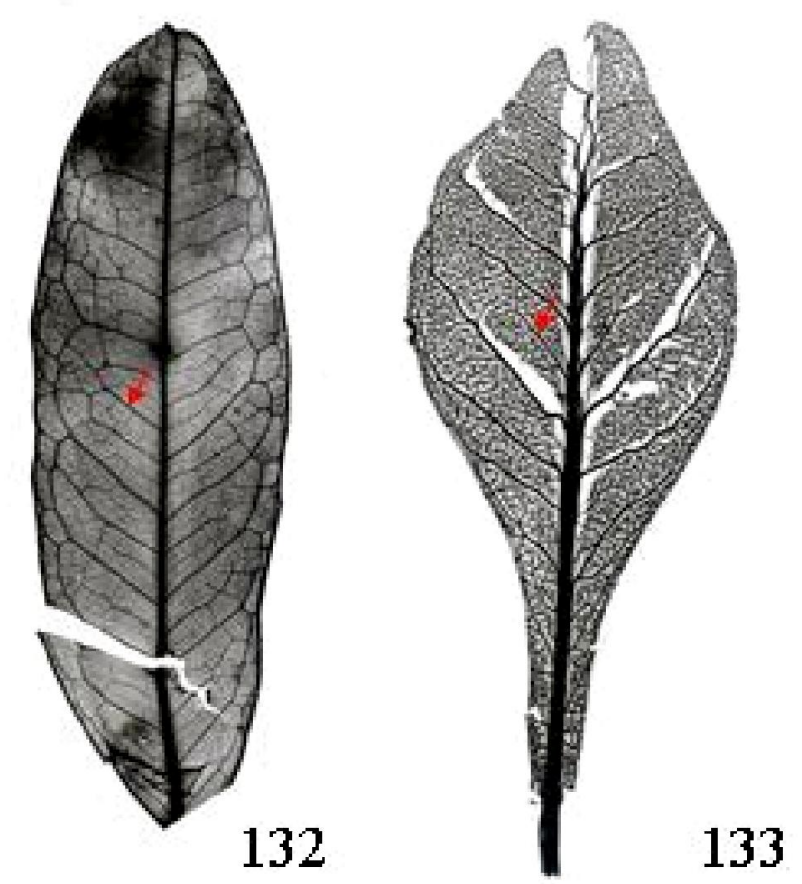

Figurs 127-133. Nervapăo do tipo camptódromo-broquidódromo observado nas espécies de Rutaceae; angulos das nervuras securdánas e oconência de intersecurdánias. 127. Filocarpus pauciflorus: ângulos uniformes. 128. Filocarpus alatus: ângulos uniformes e. 129. Helietta apiculata: angulo diminui em direçäo à base. 130. Galipea trijoliata : angulo uriforme 131. Filocarpus spicatus: ângulo uriforme. 132 . Filocarpus jaborandi: angulo aumenta em direção a base. 133. Pibcarpus microphyllus: uriforme. Legenda: setas verme lias (intersecurdarias fortes) e setas azuis (intersecurdanias fracas). 

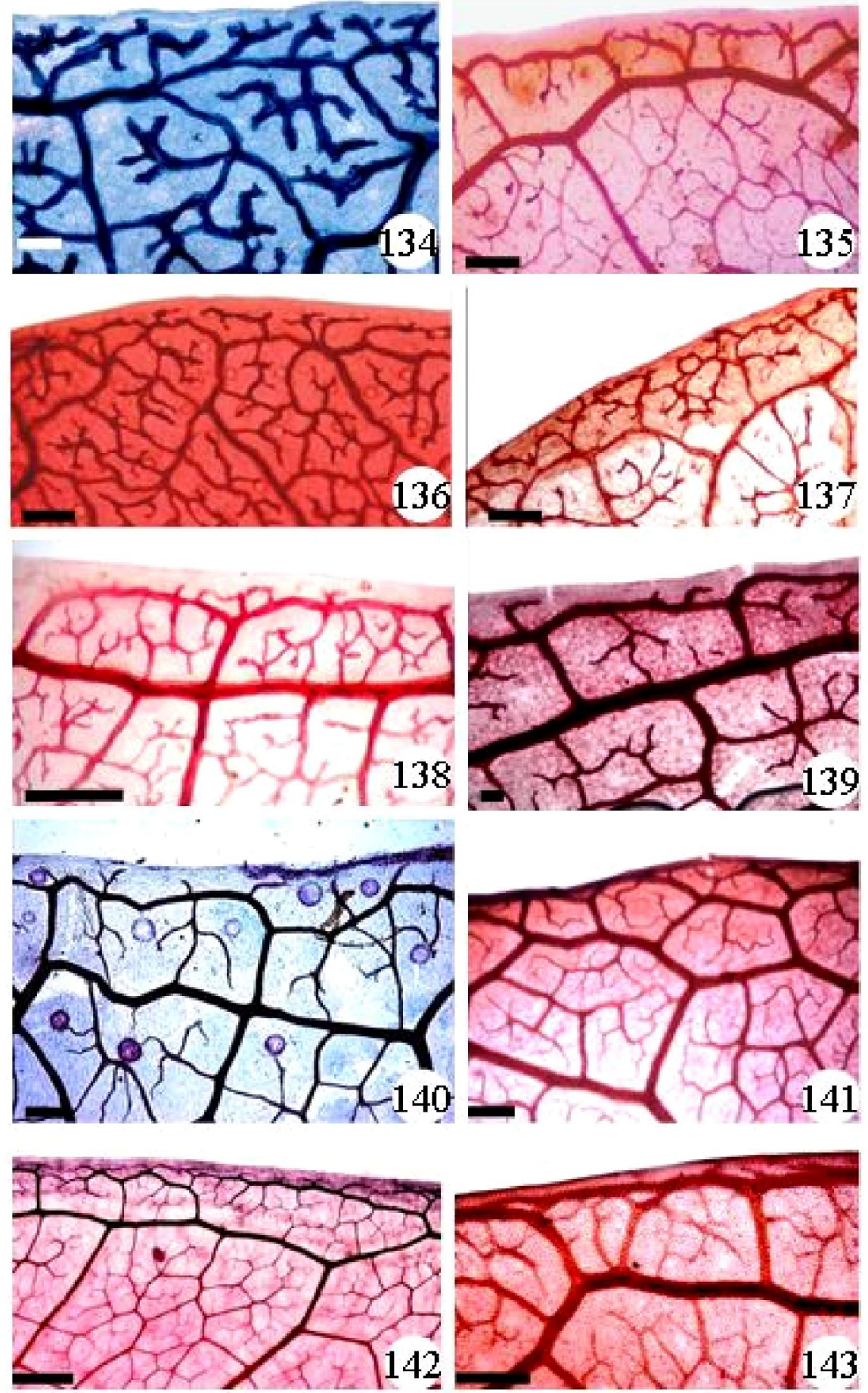

Figura 134143. Venapgo iltirna marginal. 134137. incompleta: 134. Fibocrpus microphplus. 135. Filocarpus alatus. 136. Helietta apiculata 137. Esenbecha Teiocarpa. 138-143. Em forma de arco: 138. Fibocarpus spicatus 139. Filocarpus paucfitorus. 140. Galpea tijoliata. 141. Metrodorea flavida. 142. Raulinoa echinata. 143. Filocarpus jabor andi. Barras: $134=160 \mu \mathrm{m} ; 135-138,141,143=7 \mu \mathrm{m} ; 136,139$ $140=3 \mu \mathrm{m} 142=13 \mu \mathrm{m}$ 

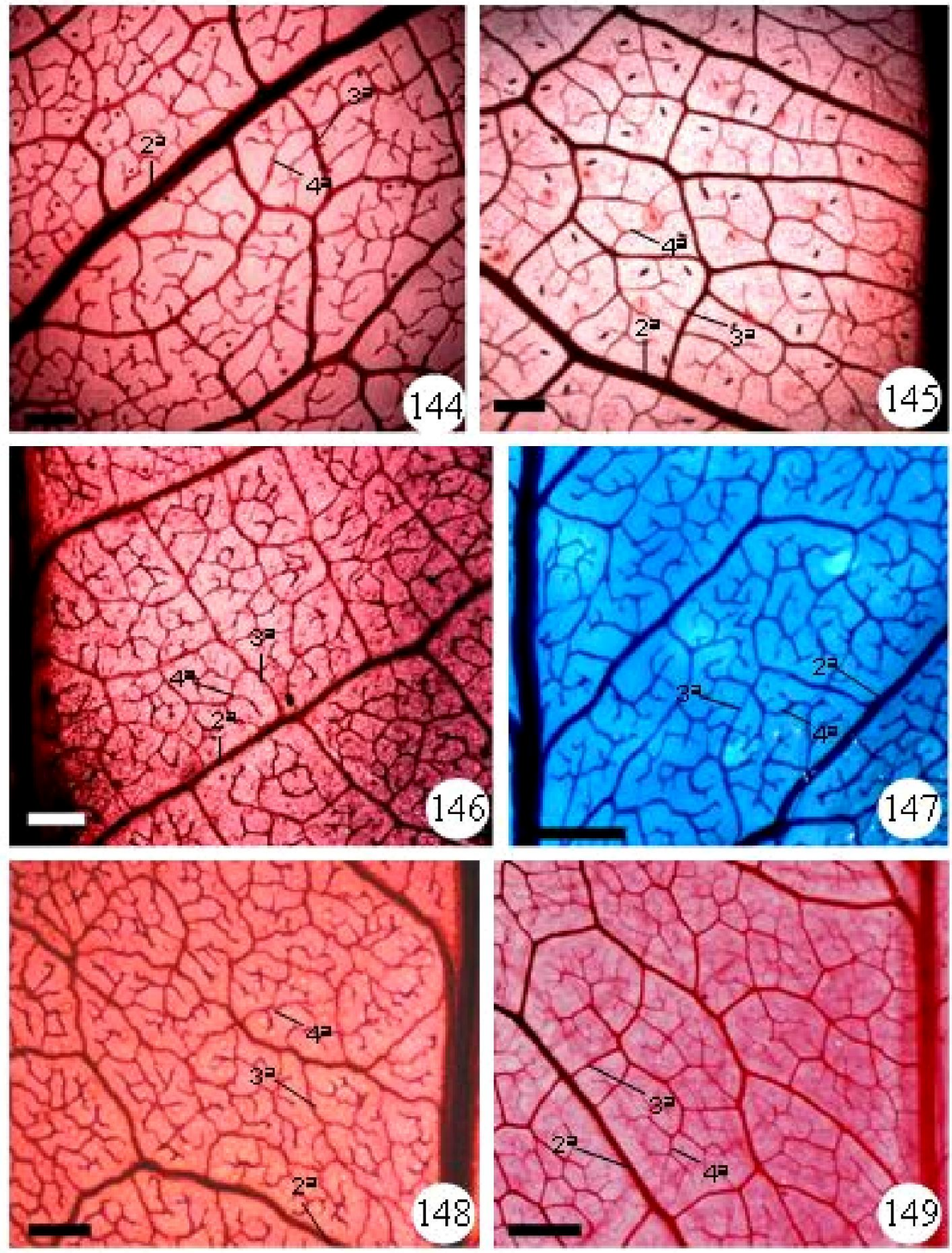

Figuras 144149. classificap̧a das nemuras terciarias (3) e quartenáias (4). 144. Pilocarpus spicatus: Pecumente altemada em ambas as nermuss. 145. Galipea trjoliata: Pecurente altemada (3) e reticulada retangular poligonal (4). 146 Esenbecha leocarpa: Fecurrente altemada (3 e 4). 147. Pilocarpus microphlus: dicotomizada $\left(3^{3}\right.$ e $\left.4^{3}\right)$. 148. Helietta apiculata: aleatoria reticulada (3) e dicotomizada (4). 149. Raulinoa echinata: aleatoriamente reticulada (3) e pecumente altemada (4). Barras: $144145,148=7 \mu \mathrm{m} ; 146=4$ $\mu \mathrm{m} ; 147,149=13 \mu \mathrm{mi}$ 

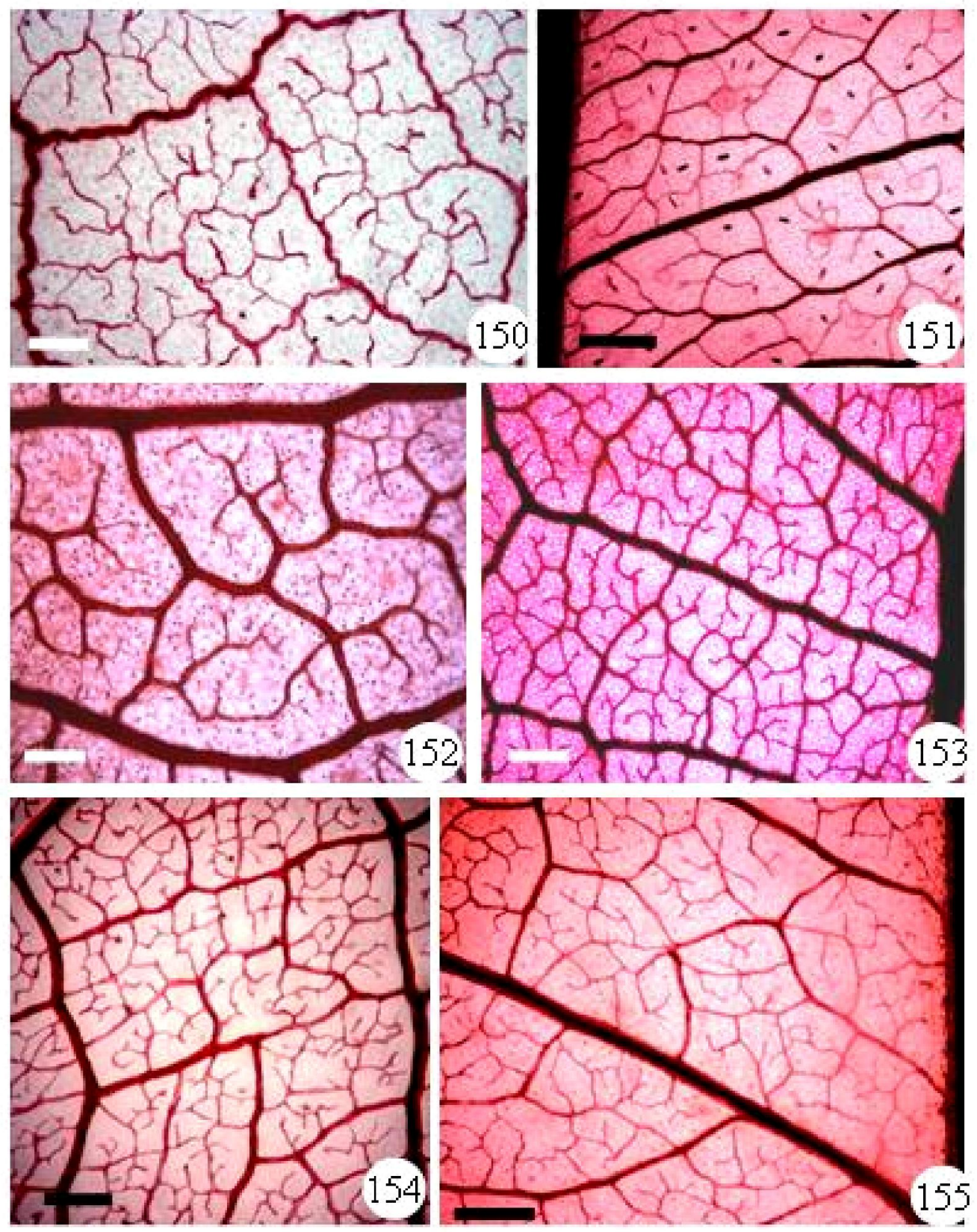

Figuras 150-155. Arélas imperfeitas e temunap̃es das nemuras. 150-154. teminacóes ramificadas: 150 . Esenbecha leiocarpa. 151. Galipea trifoliata. 152. Metrodorea flavida. 153. Filocarpus paucflorus. 154. Filocarpus spicatus. 155. Temimaca simples: Filocarpus alatus. Bamas: $150,152=3 \mu \mathrm{m} ; 151,153$ $155=7 \mu \mathrm{m}$ 

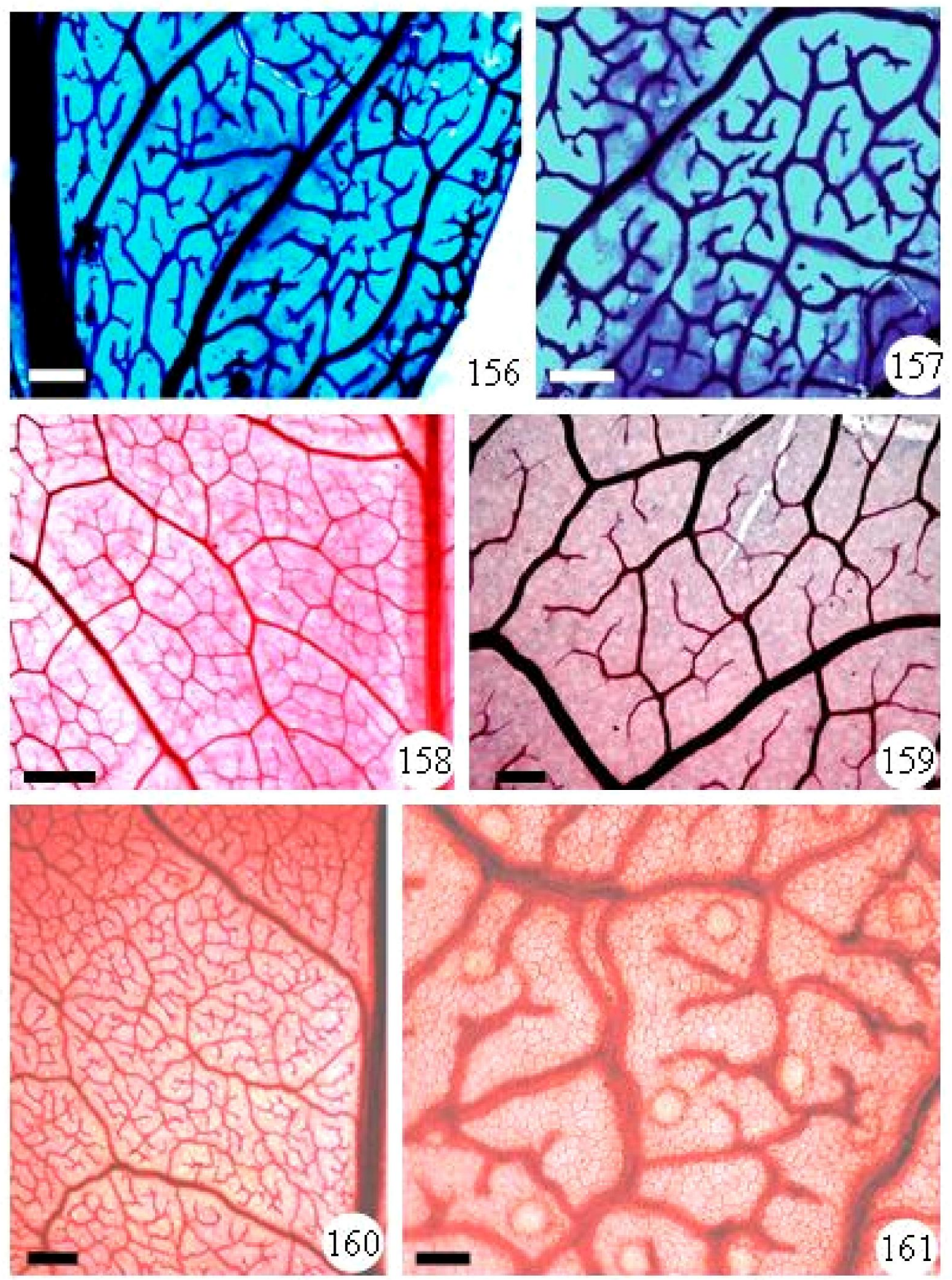

Figuas 156-161. Aréolas ircompletas e terrimą̧ón das nervuas. 156-157. Filocarpus microphyllus: idioblastos traqueoidais. 158-159. Raulinoa echinata: termiraróes rarnificadas. 160-161. Helietta apiculata: termimaģoses sirmples. Barras: $156,159=3 \mu \mathrm{m} ; 157=4 \mu \mathrm{m} ; 156,158=13 \mu \mathrm{m} ; 160=7 \mu \mathrm{m} ; 161=160$ $\mu \mathrm{m}$ 



Figuras 162-170. Seccóes transversais do peciolo: detalhe da epiderme. 162. Balfourodendron riedelianum. 163. Esenbecha leiocarpa. 164. Helietia apiculata. 165. Filocarpus alatss 166. Raulinoa echinata 167. Galpea trifoliata 168. Filocarpus giganteus. 169. Filocarpus jaborandi. 170. Fiboarpus microphilus. Legendas: $\mathrm{Fr}$ - perideme, $\mathrm{Tt}$ - tricoma tector, $\mathrm{Tg}$ - tricoma glardular, $\mathrm{Cs}$ - covidade secretora. Barras: $162,166-167=80 \mu \mathrm{m} ; 163-164,168-169=40 \mu \mathrm{m} ; 165,170=$ $160 \mu \mathrm{mr}$. 

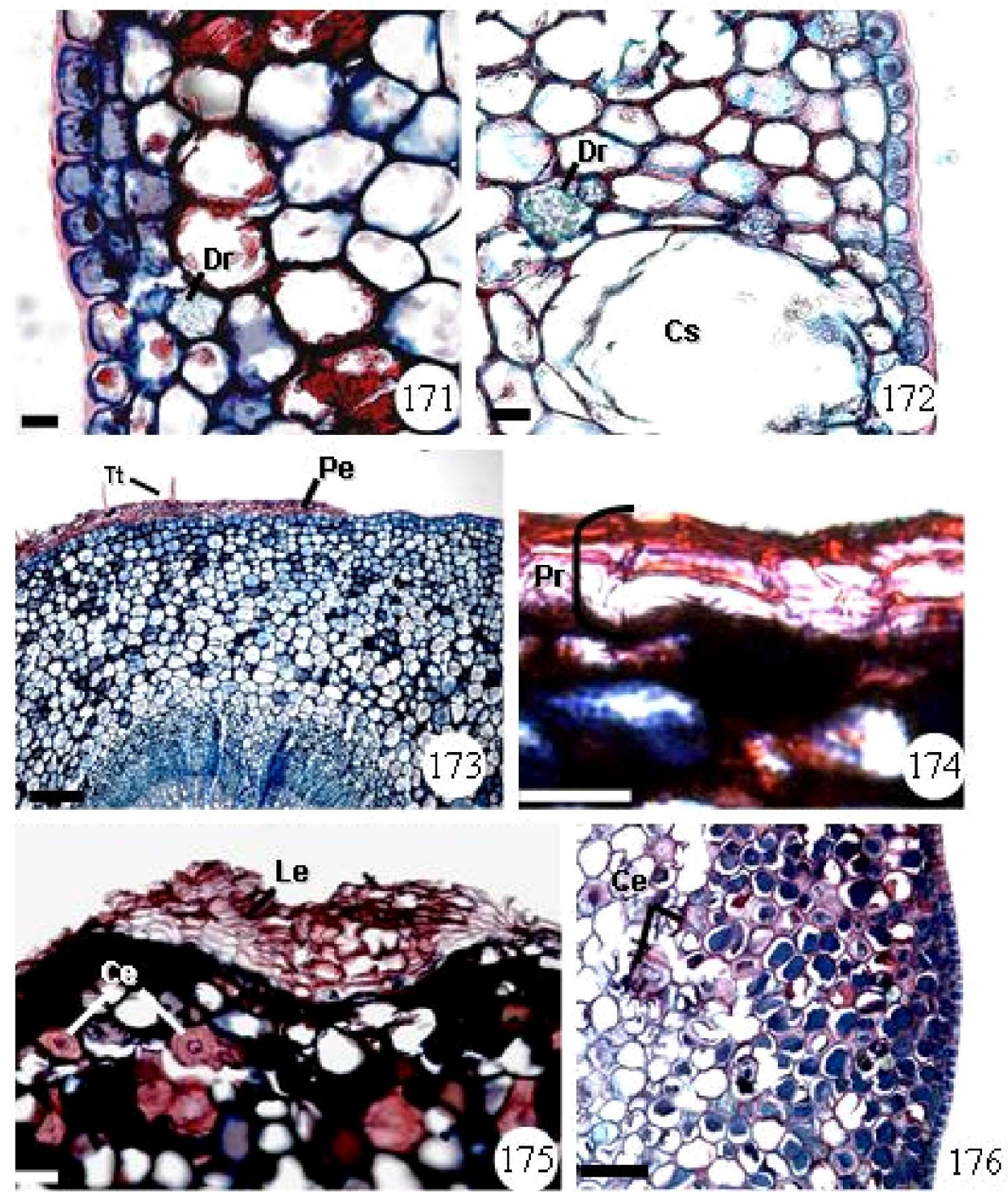

Figuras 171-175. Secpos trarsversas do peciolo: detalle da epideme 171. Filocarpus paucflorus. 172. Filocarpus spicatis. 173. Balfourodendron riedelianum. 174175. Metrodorea flavida. 176. Filocarpus giganteus. Legendas: Dr - drusa, $\mathrm{Pr}-$ Feriderme, Le - Lenticela, Ce - Célula esclerenquirnática, $\mathrm{Cs}$ - Cavidade secretora. Barras: $171,175-176=80 \mu \mathrm{m} ; 172,174=40 \mu \mathrm{m} ; 173=160 \mu \mathrm{m}$. 



Figuras 177-184. Seccóes tranoversas do peciolo: colura da direita com lus polarizada e colura da esquerda serm luz polarizada. 177-178. Filocarpus giganteus: drusas de oxalato de calcio. 179-180.Pibcarpus microphilus: drusas de oxalato de odcio. 181-182. Galipea trifo iata: Rafides e cristais primaticos. 183-184. Esenbecha leiocara: cristais prinaticos. Barras: $177-184=80 \mu \mathrm{m}$. 


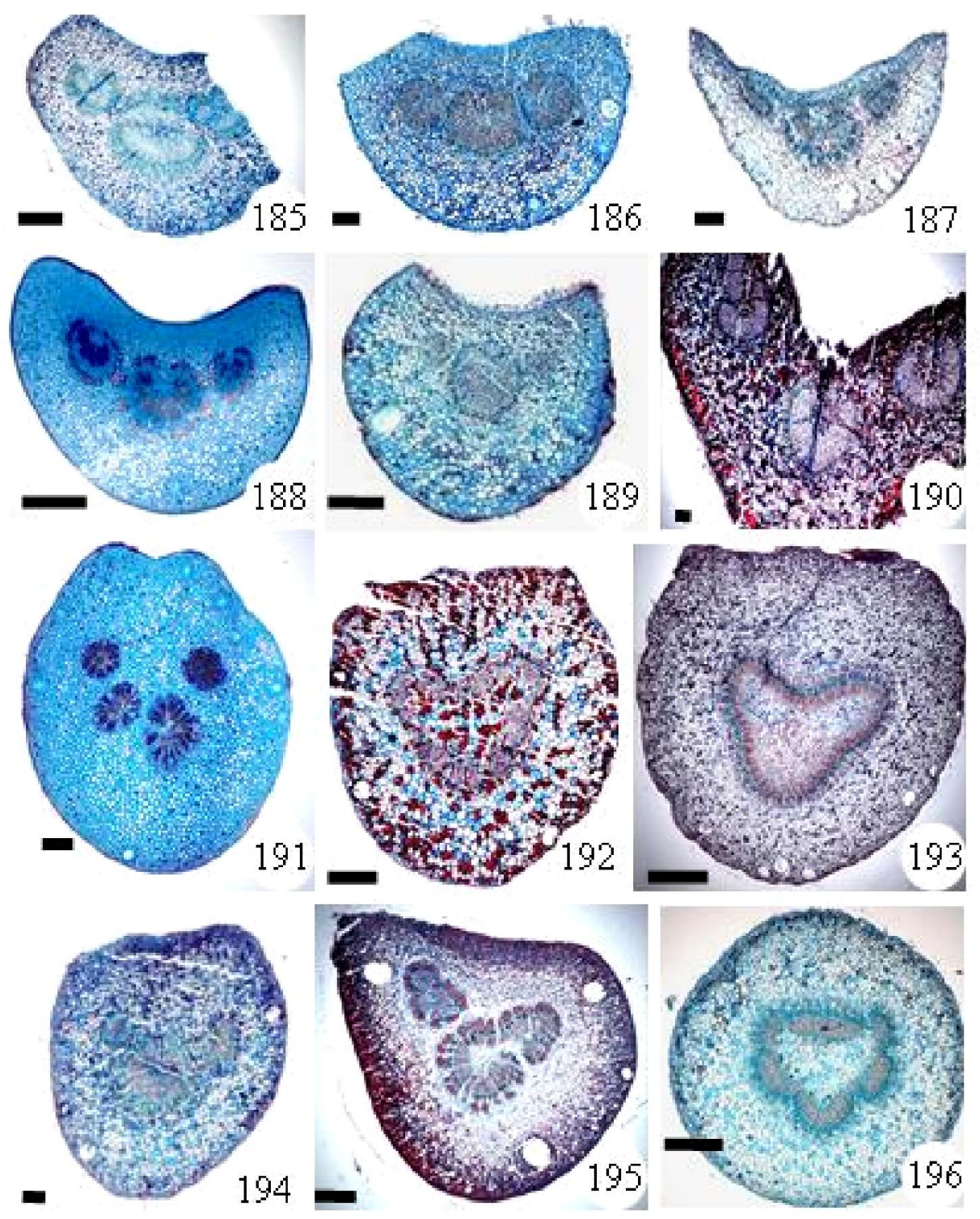

Figura 185-196. Secçós transversas da regiăo basal do peciolo: aspecto geral. 185. Balfourodendron riedelianum. 186. Helietta apiculata. 187. Filocarpus spicatus. 188. Pilocarpus pauciflorus 189 . Raulinoa echinata 190. Metrodorea flavida. 191. Filocarpus alatus. 192. Galipea trifoliata. 193. Filocarpus jaborandi. 194. Fiboarpus microphylus. 195. Filocarpus giganteus. 196. Esenbecha leiocarpa. Banas: $185,190-191,193,195-196=640 \mu \mathrm{m} ; 186-189,192,194=$ $340 \mu \mathrm{m}$. 

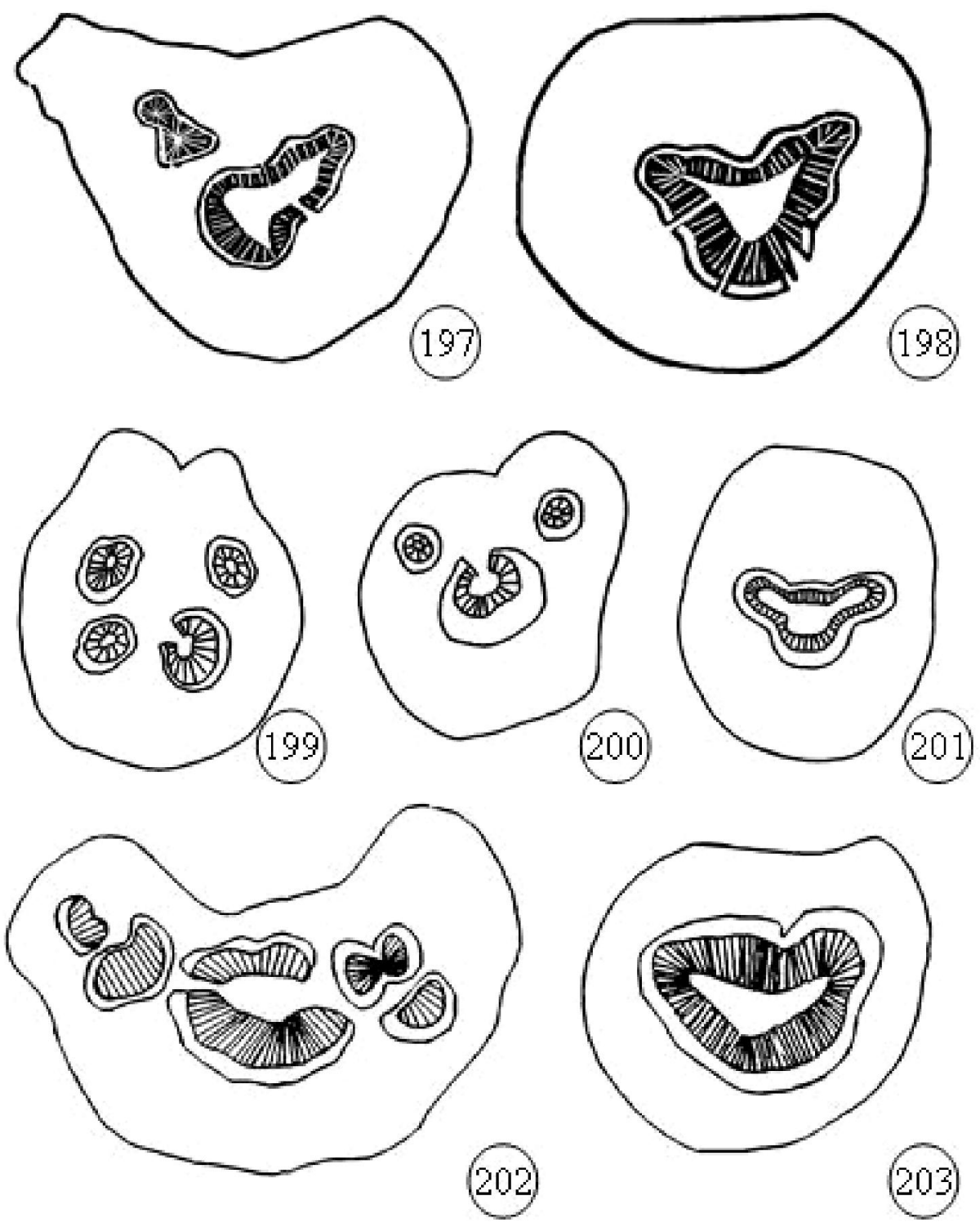

Legenda: $\quad \square$ Floema III Xilema

Figuras 197-203. Deserbos dos peciolos na regia basal (coluna a esquerda) e mediana a apical (coluna a direita): detalhe da variaça do contomo e do sisterna vascular entre estas regióes: 197-198. Fibocarpus giganteus. 199-201. Fibocarpus alatus. 202-203. Balfourodendron riedelianum. 

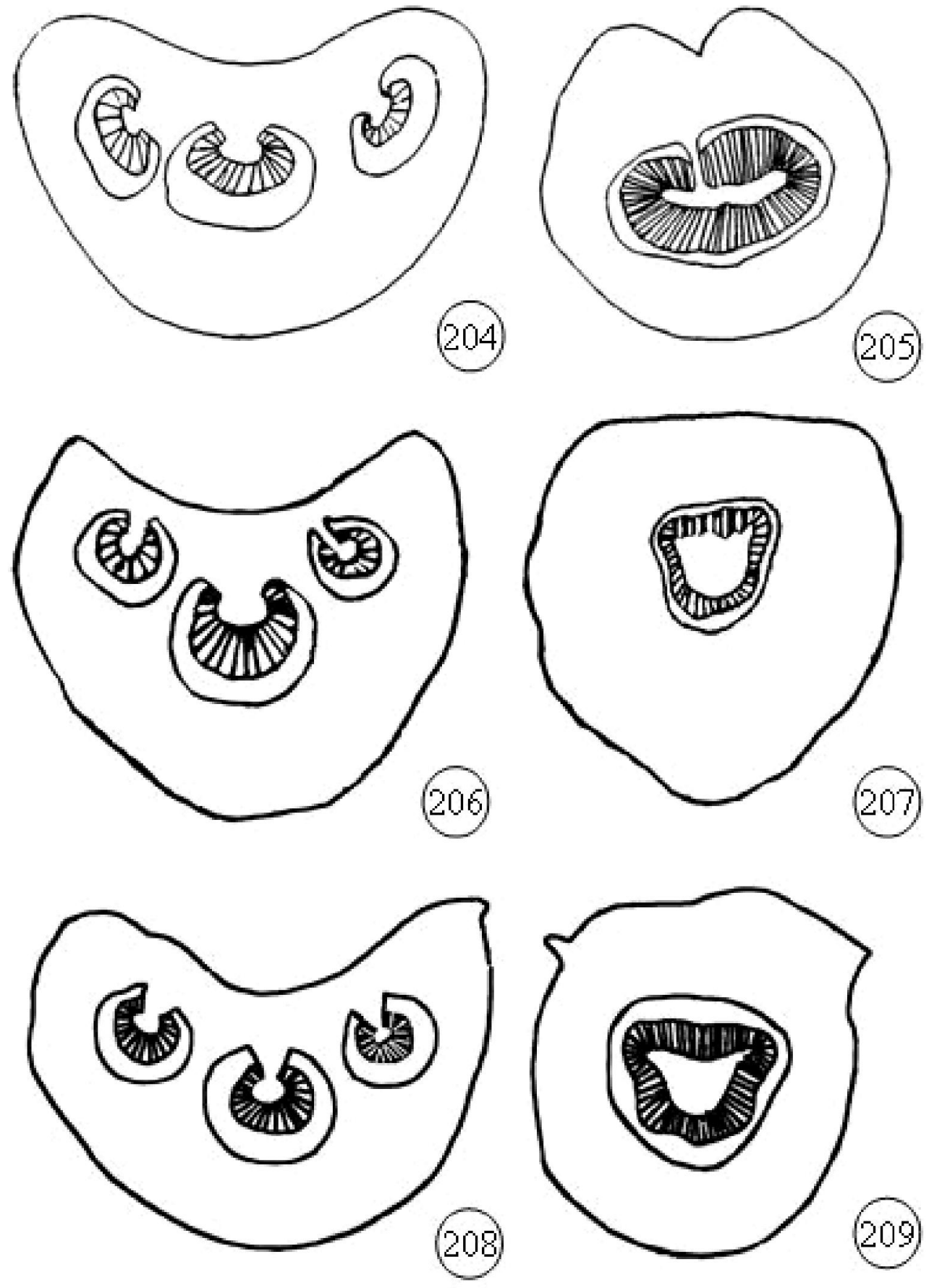

Legenda: $\quad \square$ Floema III Xilema

Figuras 204209 . Desertus dos peciolos na regian basal (coluna a esquerda) e mediana a apical (coluna a direita) - detalle da variaça do contomo e do sistema vascular entre estas regiöes: 204205. Helietta apiculata. 206-207. Faulino echinata. 208-209. Fibearpus pauciforus. 

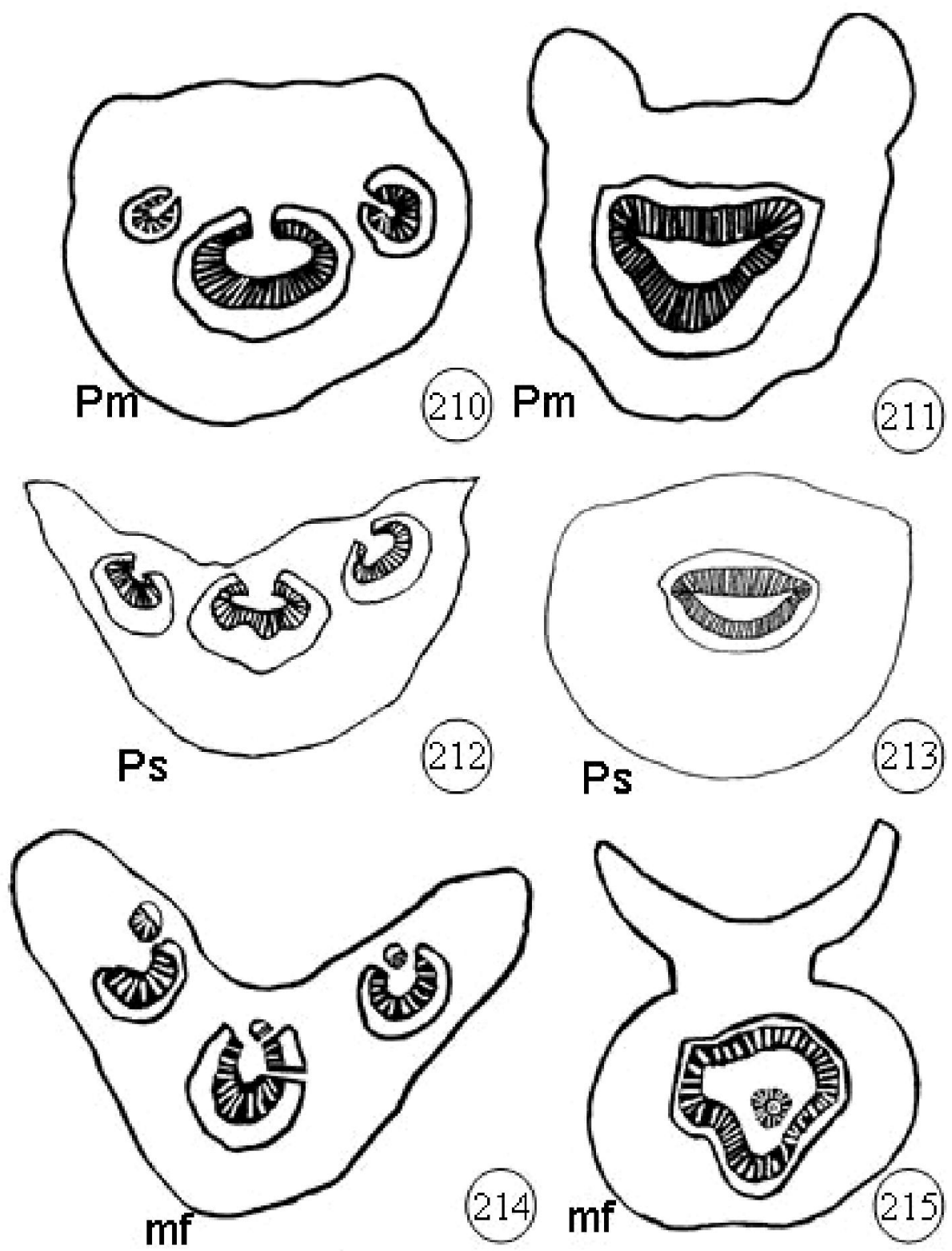

Legenda:

Floema III Xilema

Figura 210-215. Desertus dos peciolos na regia basal (colura a escuerda) e mediana a apical (coluna a direita) - detallue da variaça do contomo e do sistema vacular entre estas regiós: 210-211. Filocarpus morophilus. 212213. Filocarpus spicatus. 214215. Metrodorea flavida. 

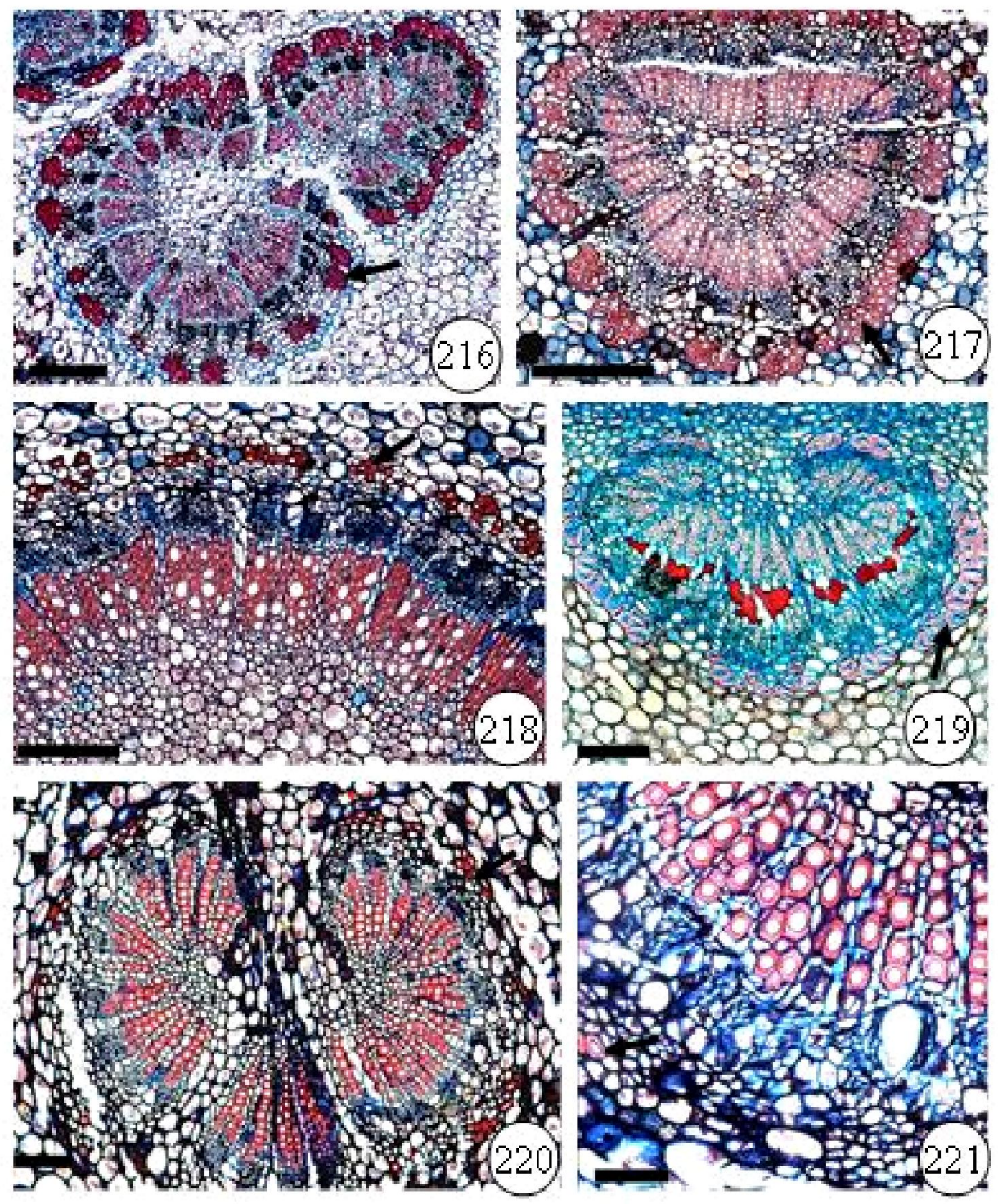

Figuras 216-221. Seccóes trarbversais do peciolo: Notar as fibras do sistema vacular (setas) 216. Filocarpus giganteus. 217. Pilocarpus paucjforus. 218. Filocarpus jaborandi. 219. Filocarpus spicatus. 220. Filocarpus alatus. 221. Filocarpus morophilus. Bama: $216=1000 \mu \mathrm{m} ; 217-219,221=520 \mu \mathrm{m} ; 220=$ $320 \mu m$. 



Figuras 222-227. Secpónes trarswersais do peciolo: detalke do sisterna vascular. 222. Raulinoa echirata. 223. Esenbecha leiocarpa. 224. Galipea trifoliata. 225. Helietta apiculata. 226. Metrodora flavida. 227. Balfourodendron riedelianum. Barras: $222=120 \mu \mathrm{rr} ; 223,227=160 \mu \mathrm{m} ; 224,226=320 \mu \mathrm{mr} ; 225=80 \mu \mathrm{mL}$. 

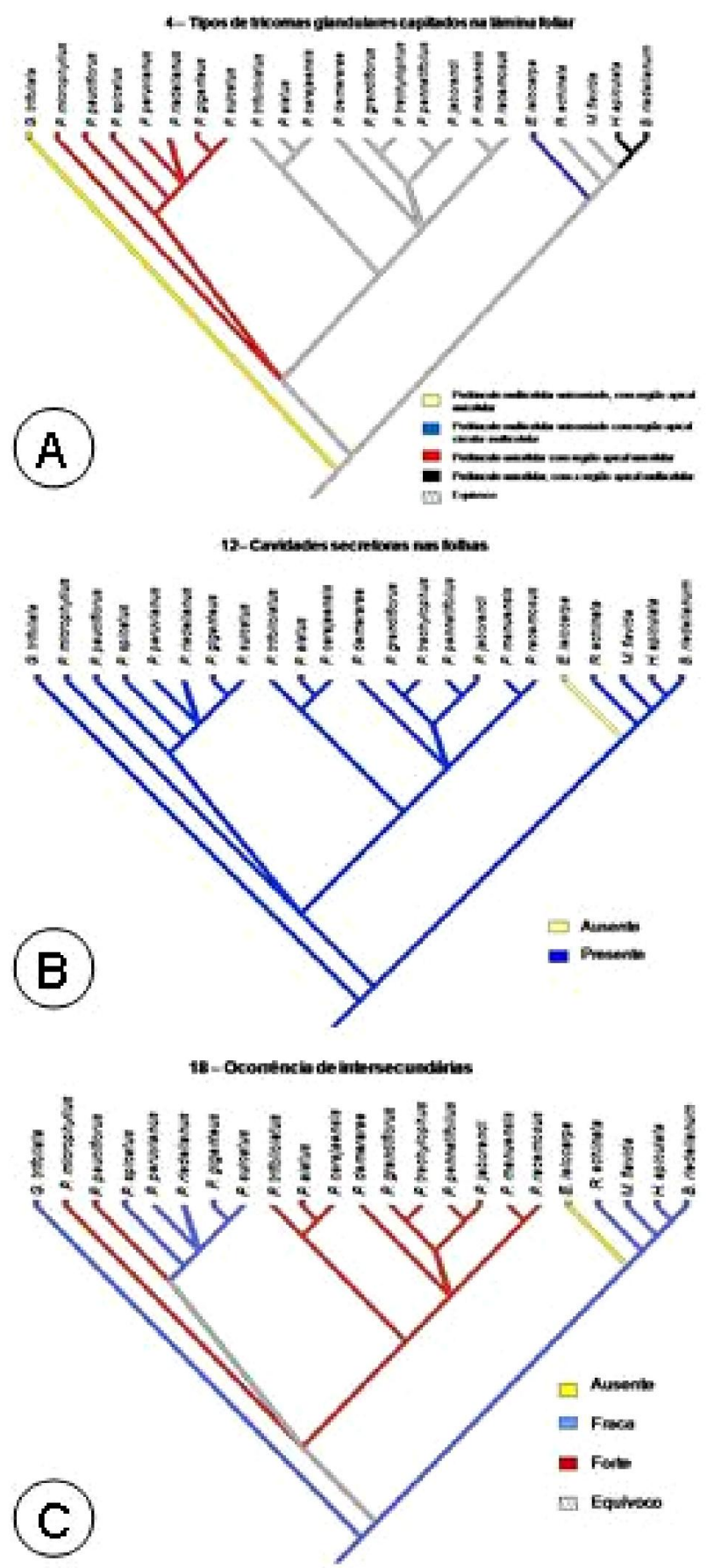

Figura 229 A.C. Mapearuento do caracteres $4,12,18,27$ e 28 . A. Tijos de tricomas glandulares capitados na lâmina foliar. B. Cavidades secretoras na folla. C. Oconênucia de intersecurdária. 

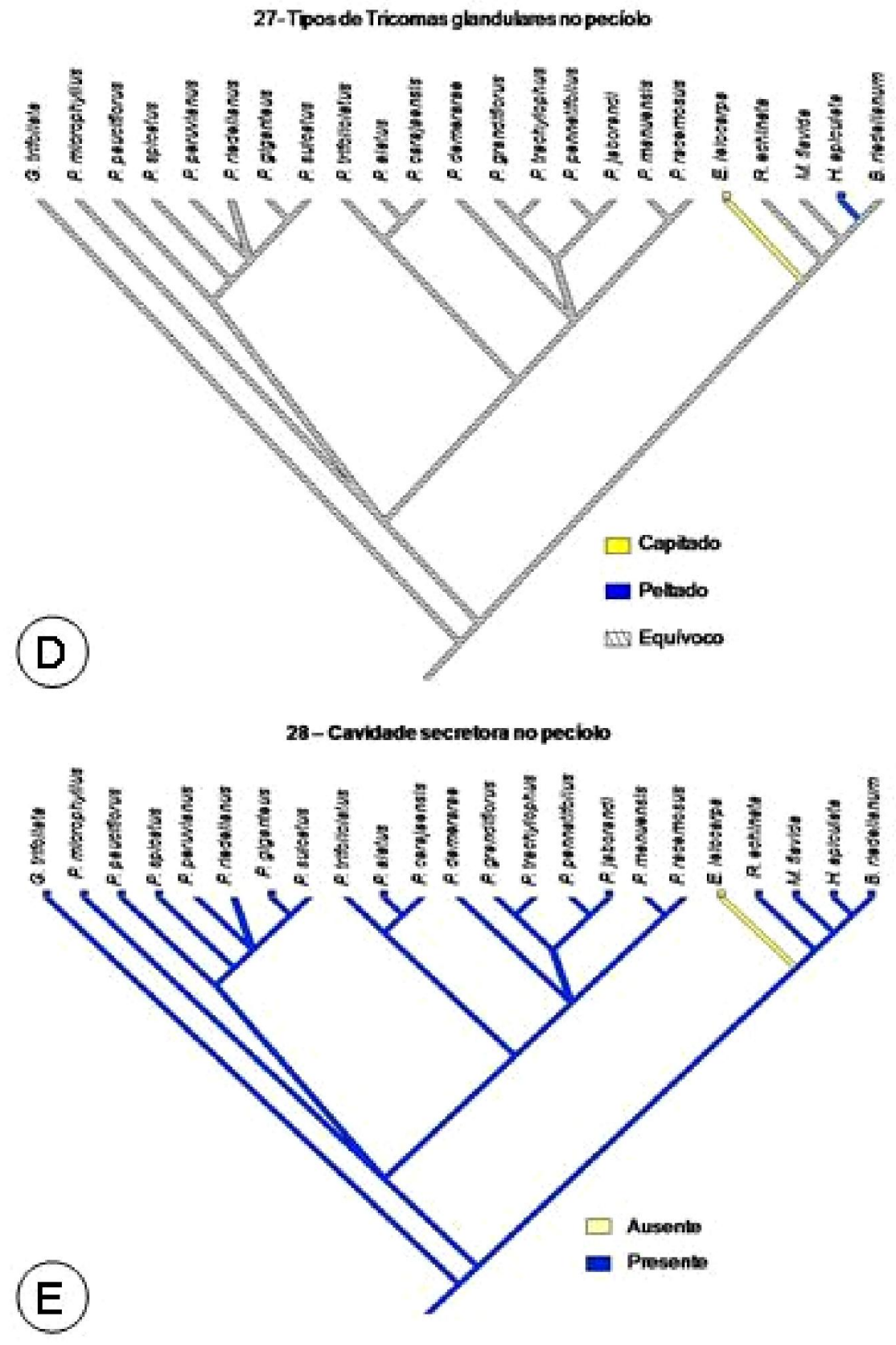

Figura 229 D-E (contimuaço). Mapearnento do caracteres 4, 12, 18, 27 e 28. D. Tipos de tricomas glandulares no peciolo. E. Cavidades secretoras no peciolo. 

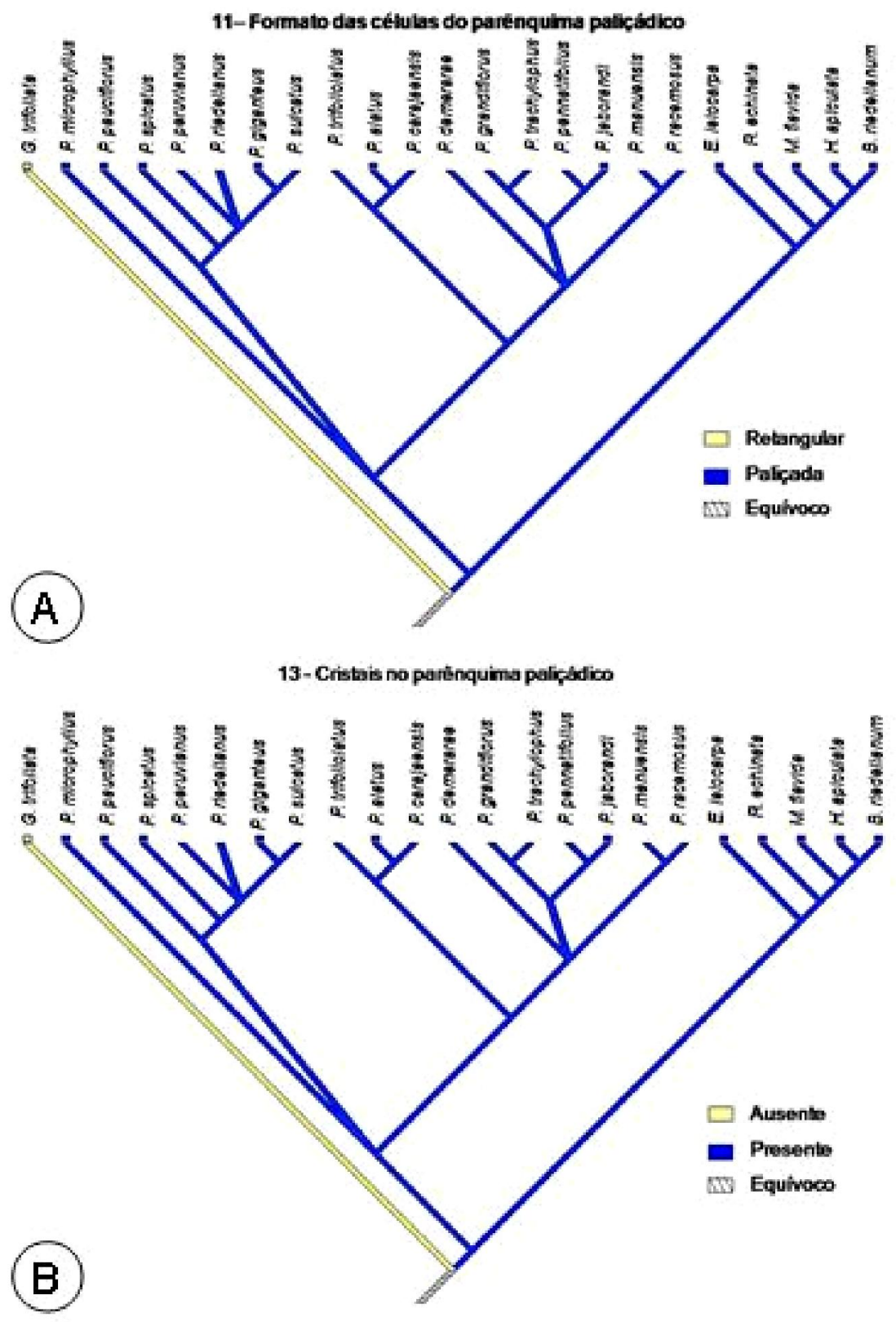

Figuras 230 A-B. Mapeamento do caracteres $4,11,13$ e 29 . A. Formato das células do parênquima paliçádico. B. Cristais no parêruquima paligádico. 

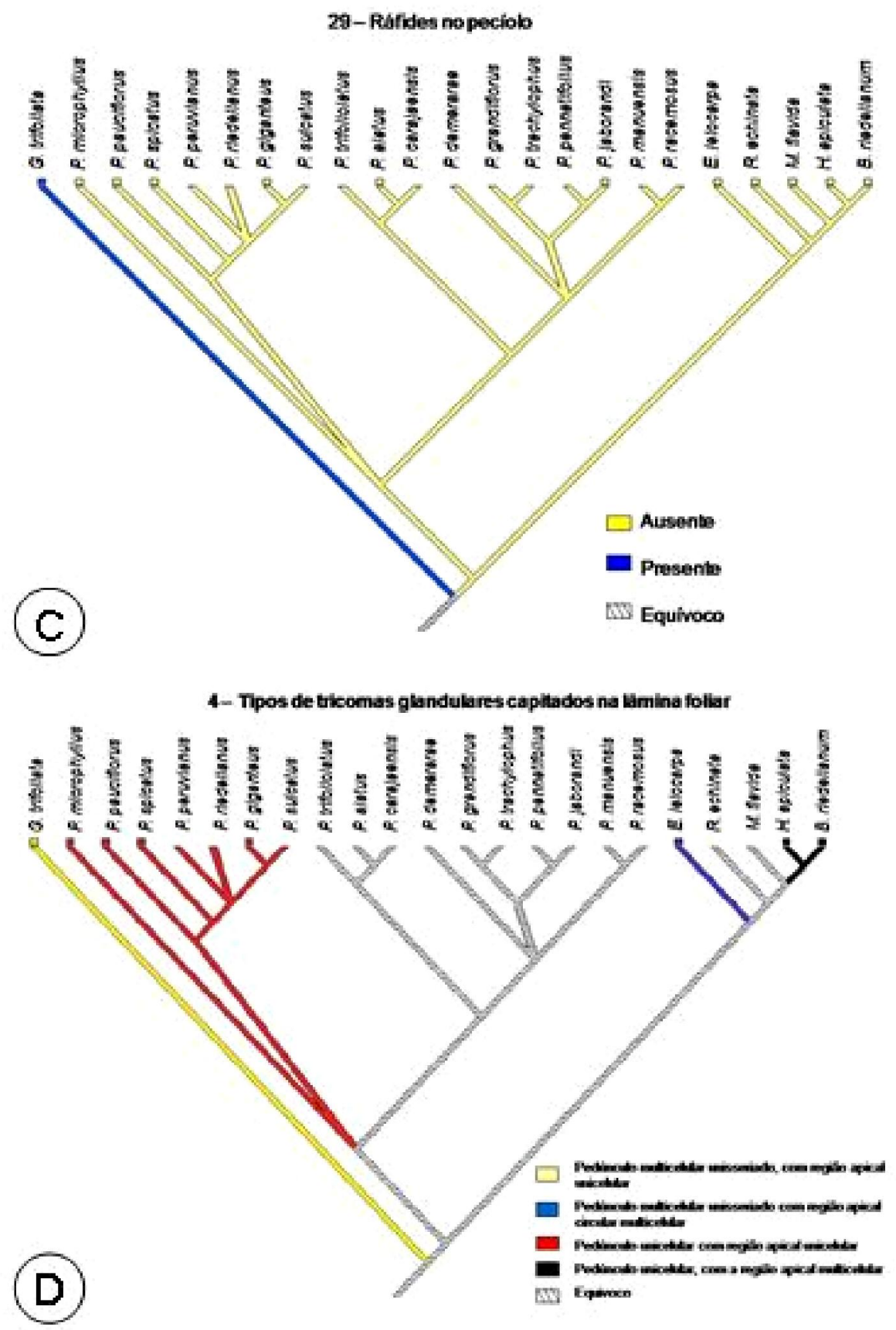

Figuras 230 C-D (contimagá). Mapearnento do camateres 4, 11, 13 e 29. C. Rafides no peciolo. D. Tipos de tricomas glandulares capitados na lârrima folliar. 


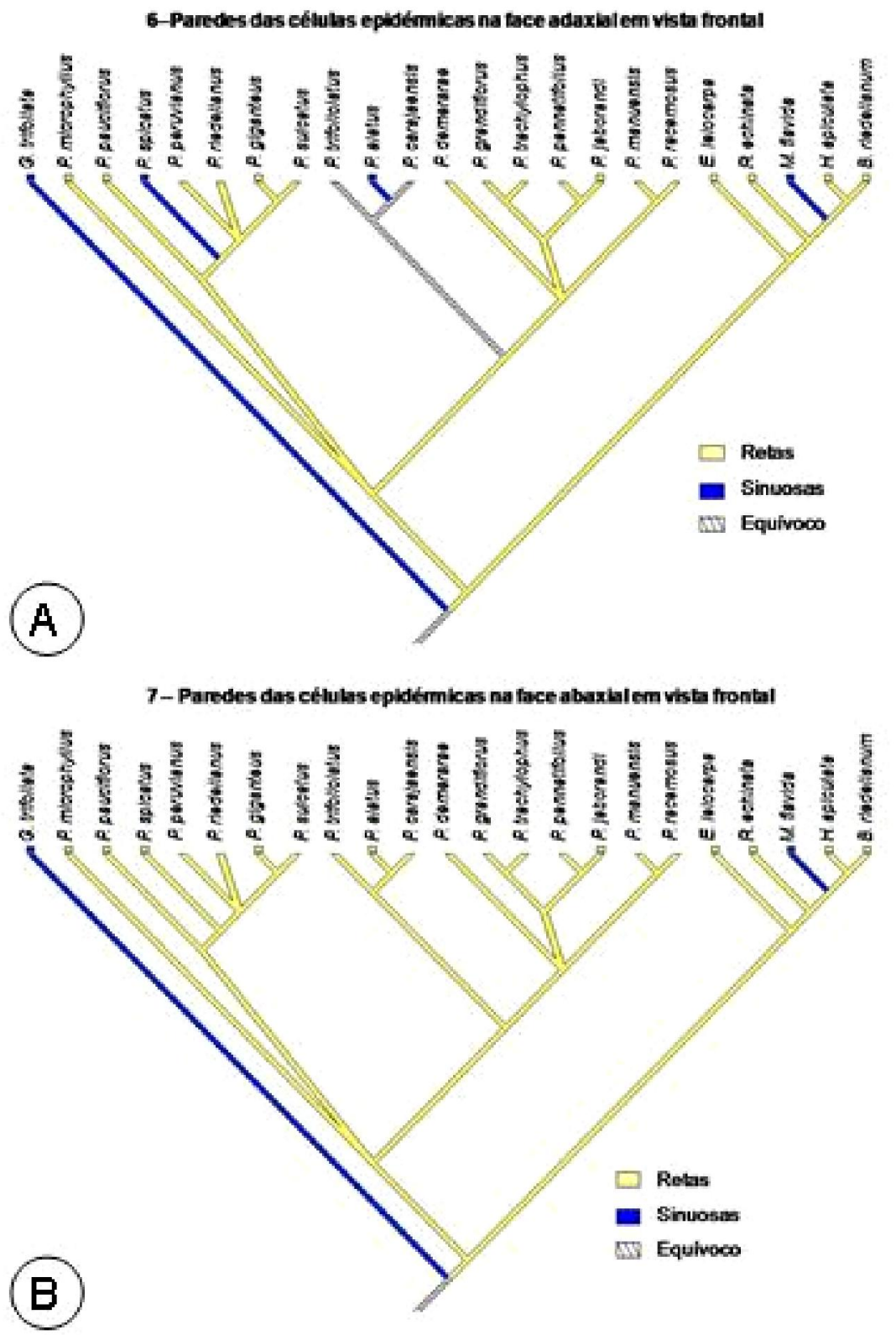

Figuras 231 A-B. Mapeamento do caracteres 6 e 7 . A. Faredes das células epidérmicas na face adaxial em vista frontal. B. Faredes das células epidenricica na face abaxial en vista frontal. 

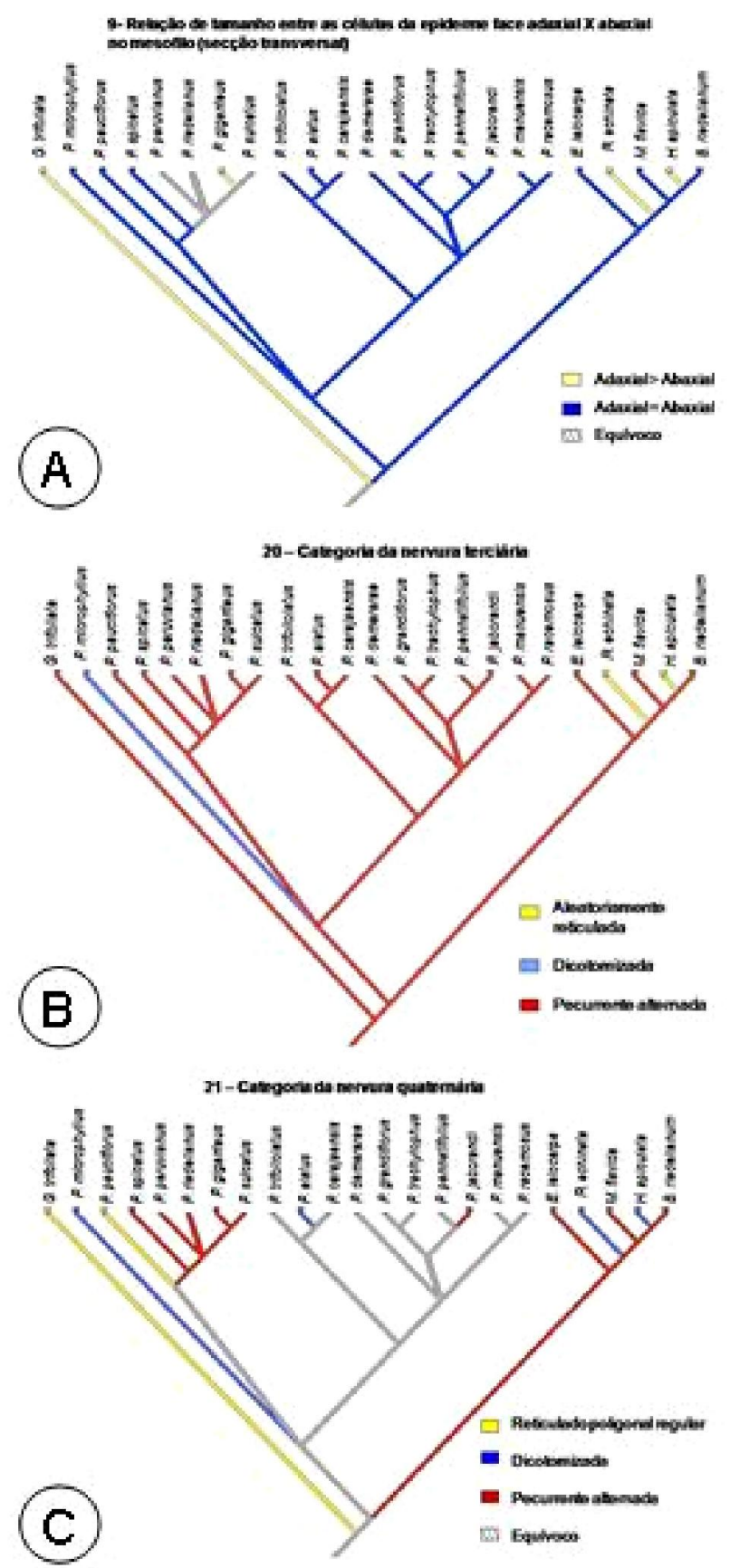

Figura $232 \mathrm{~A}-\mathrm{C}$. Mapearento do caracteres $9,8,15,20,21$ e 22 . A. Relaçäo de tamarto entre as celulas da epideme face adaxial $X$ abaxial no mesofilo (secpäo transwersal). B. Categoria da nemura terciaria. C. Categoria da nemura quatemária. 


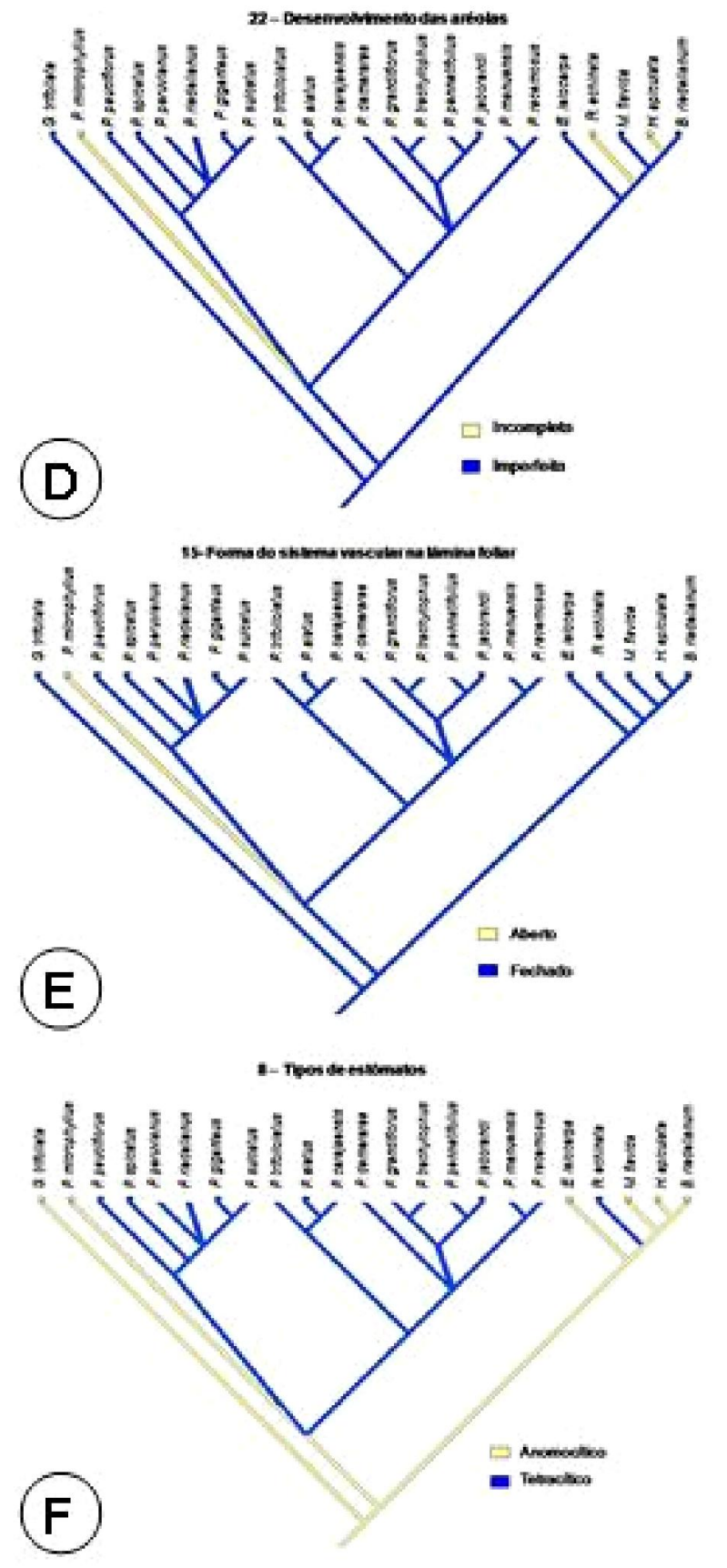

Figuras 232 D-F (contimuąă). Mapearuento do caracteres 9, 8, 15, 20, 21 e 22. D. Deservolvirnento das aréolas. E. Fomas do sisterna vascular na lâruiria foliar. F. Tipos de estôrratos. 


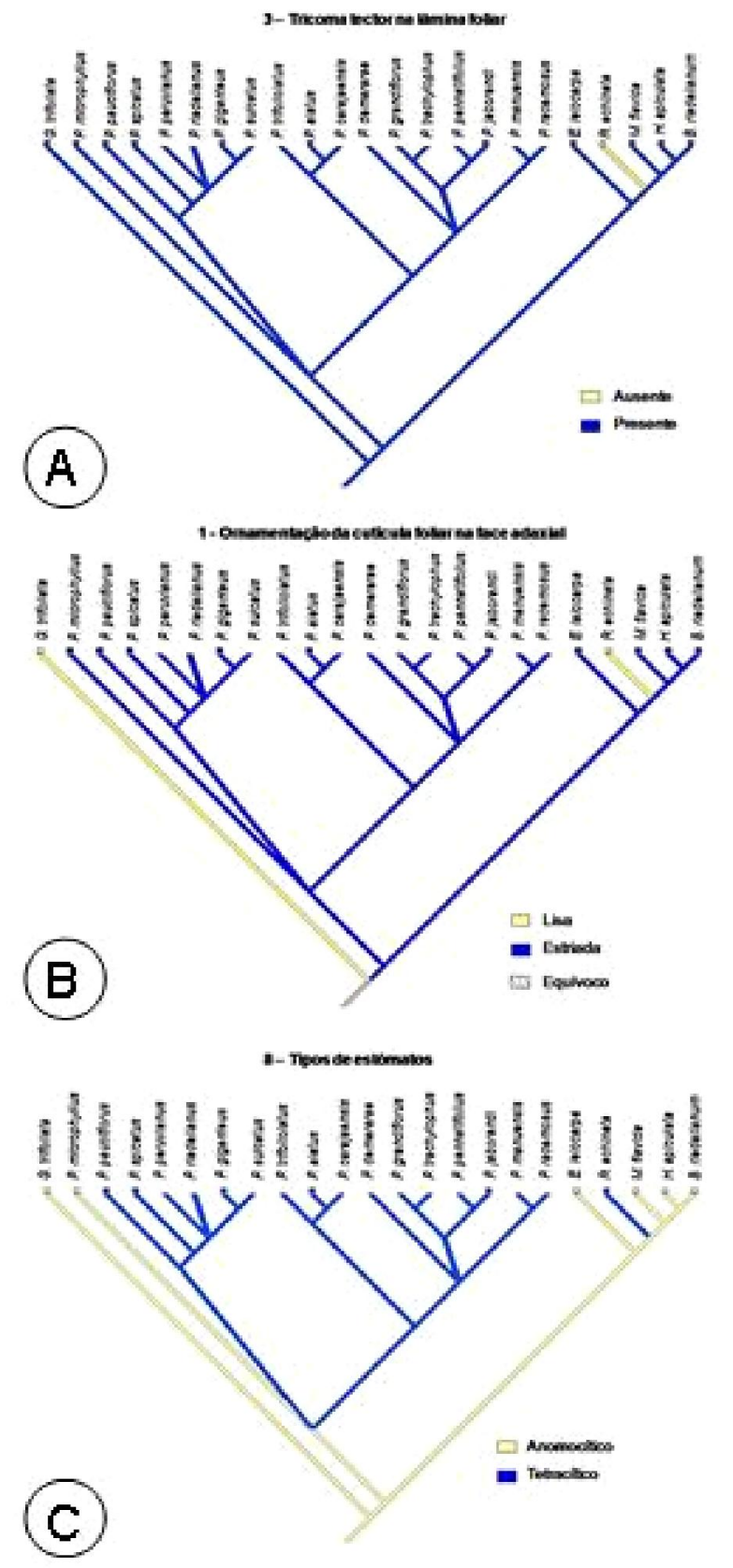

Figura 233 A-C. Mapearnento do caracteres 1,3 e 8 . A. Tricoma tector na larrima foliar. B. Omarmentagáo da cutioula foliar na face adaxial. C. Tipos de estônatos. 

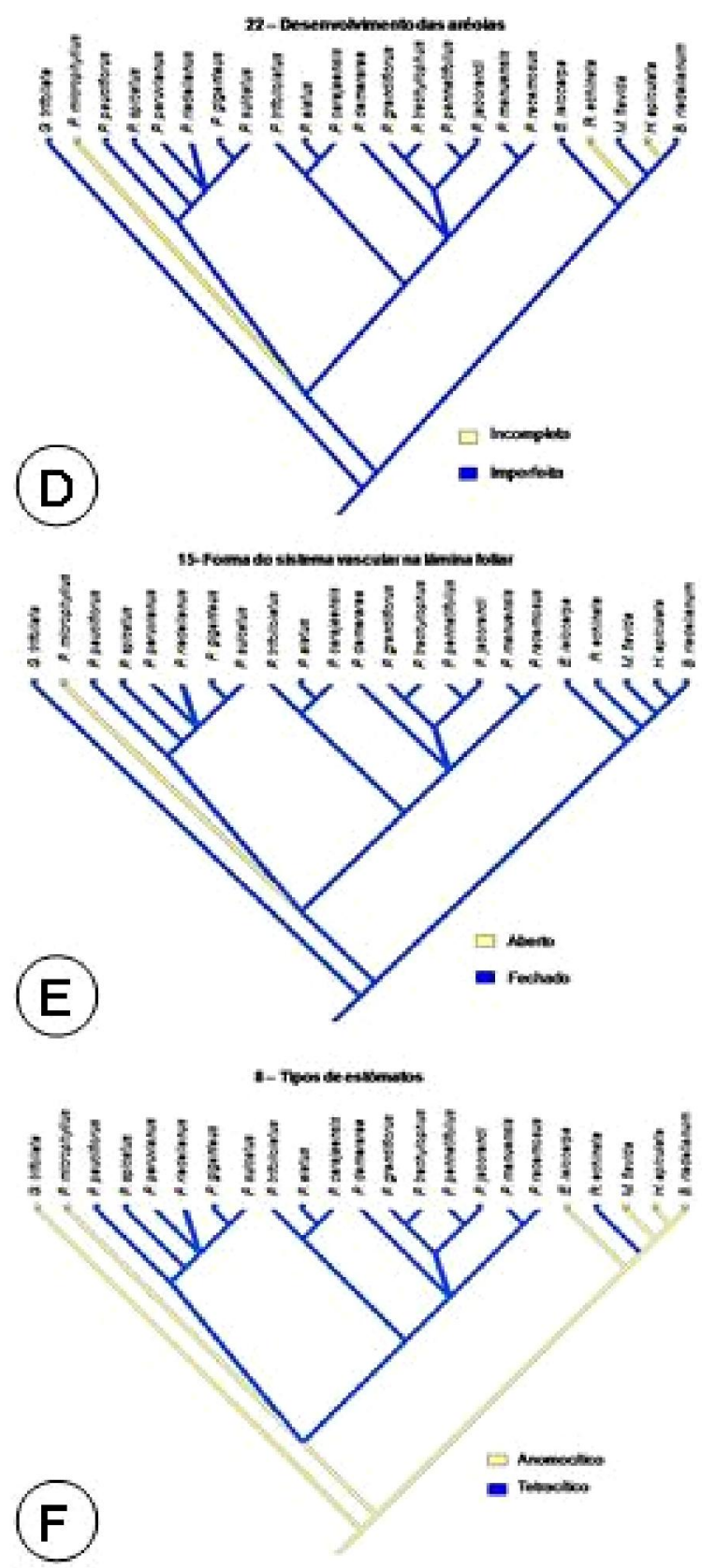

Figura $233 \mathrm{D}-\mathrm{F}$ (continuagä). Mapeamento do caracteres 9, 8, 15, 20, 21, 22. D. Deserwolvimento das aréolas. E. Formas do sisterna vascular na lârmira foliar. F. Tipos de estômatos. 

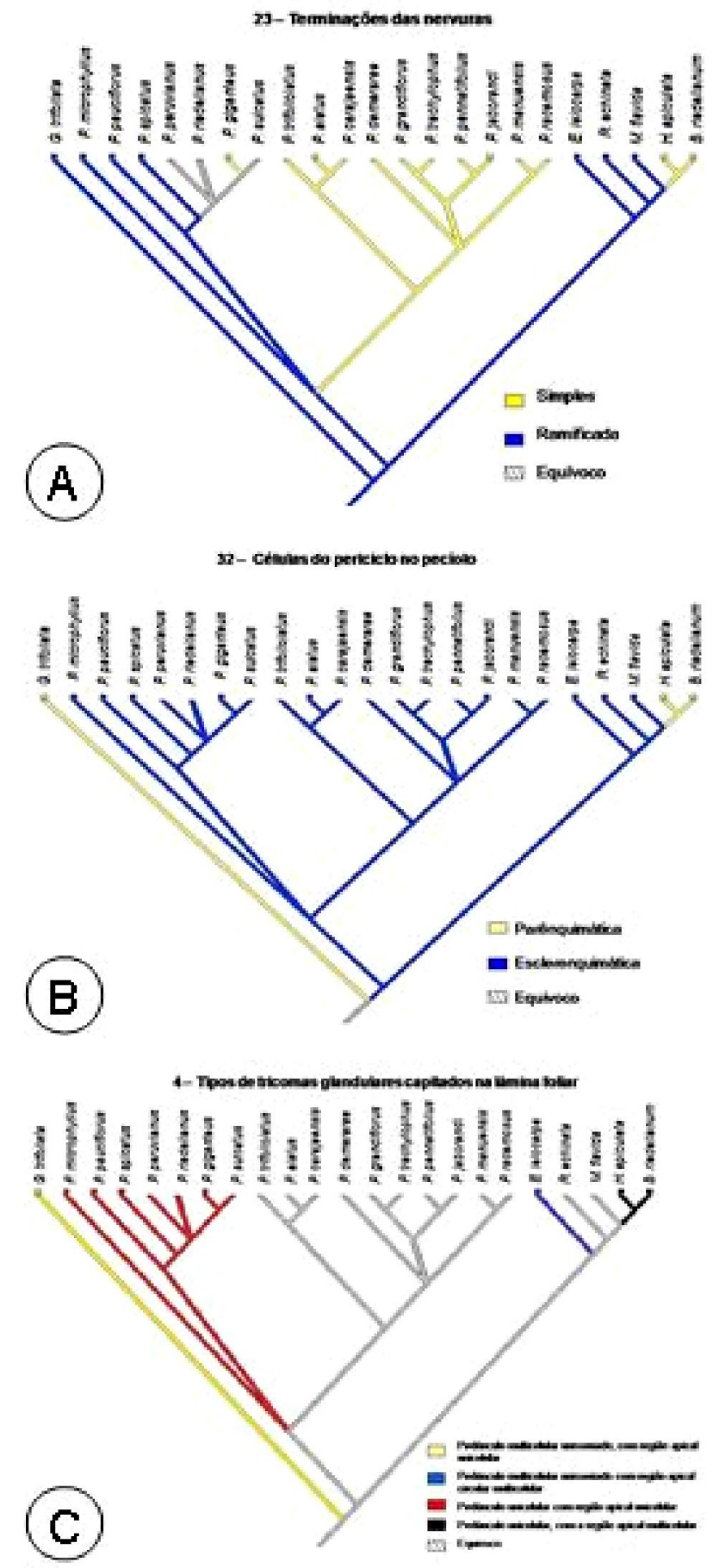

Figura 234 A-C. Mapearnento do caracteres 4,23 e 32. A. Teminaçoses das numuras. B. Celulas do periclico no peciolo. C. Tipos de tricomas glandulares capitados na làrina foliar. 

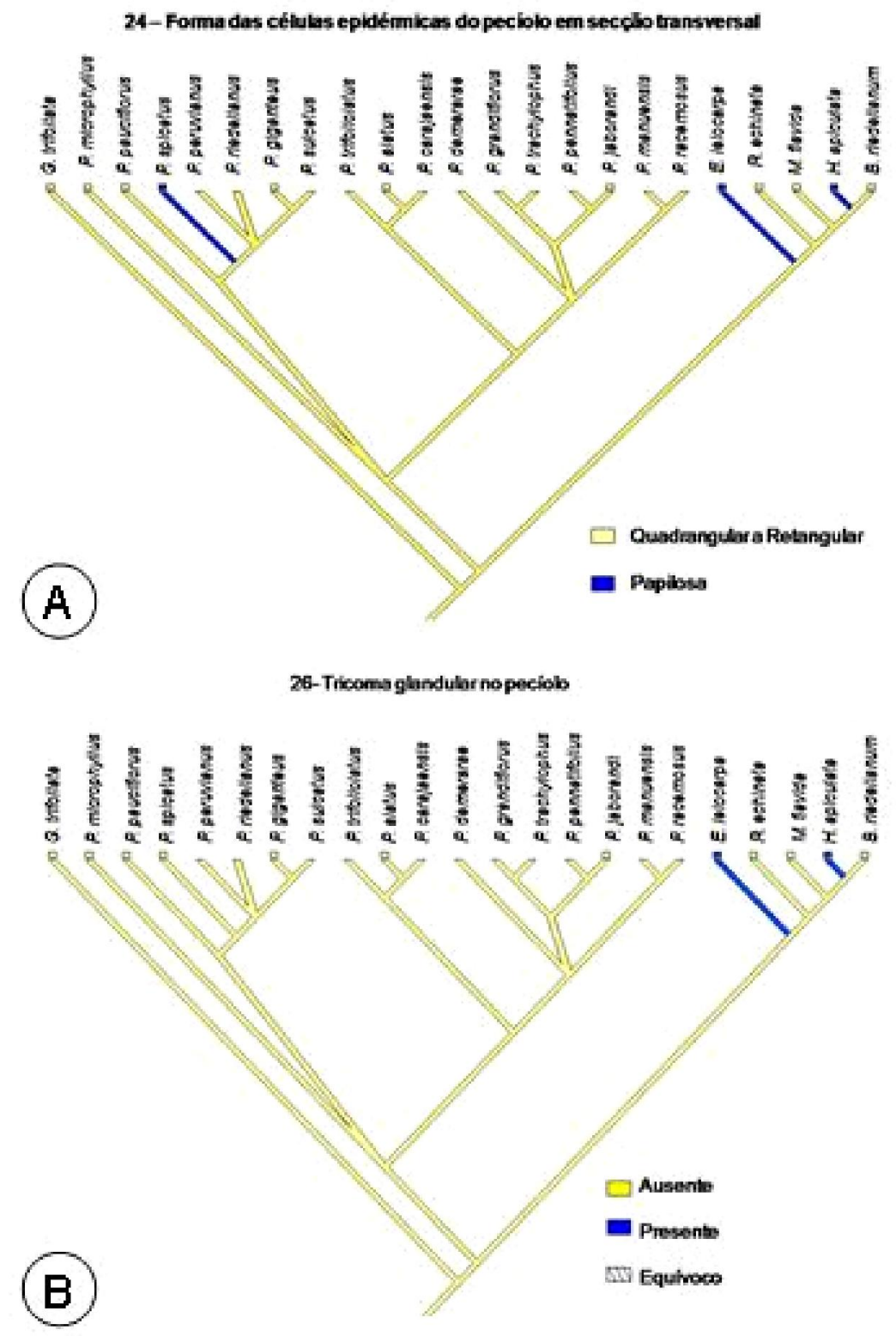

Figuras 235 A-B. Mapeamento do caracteres $10,24,26$ e 27 . A. Formas das células epidérmicas do peciolo em secräa transversal. B. Tricomas glardulares no pecíolo. 

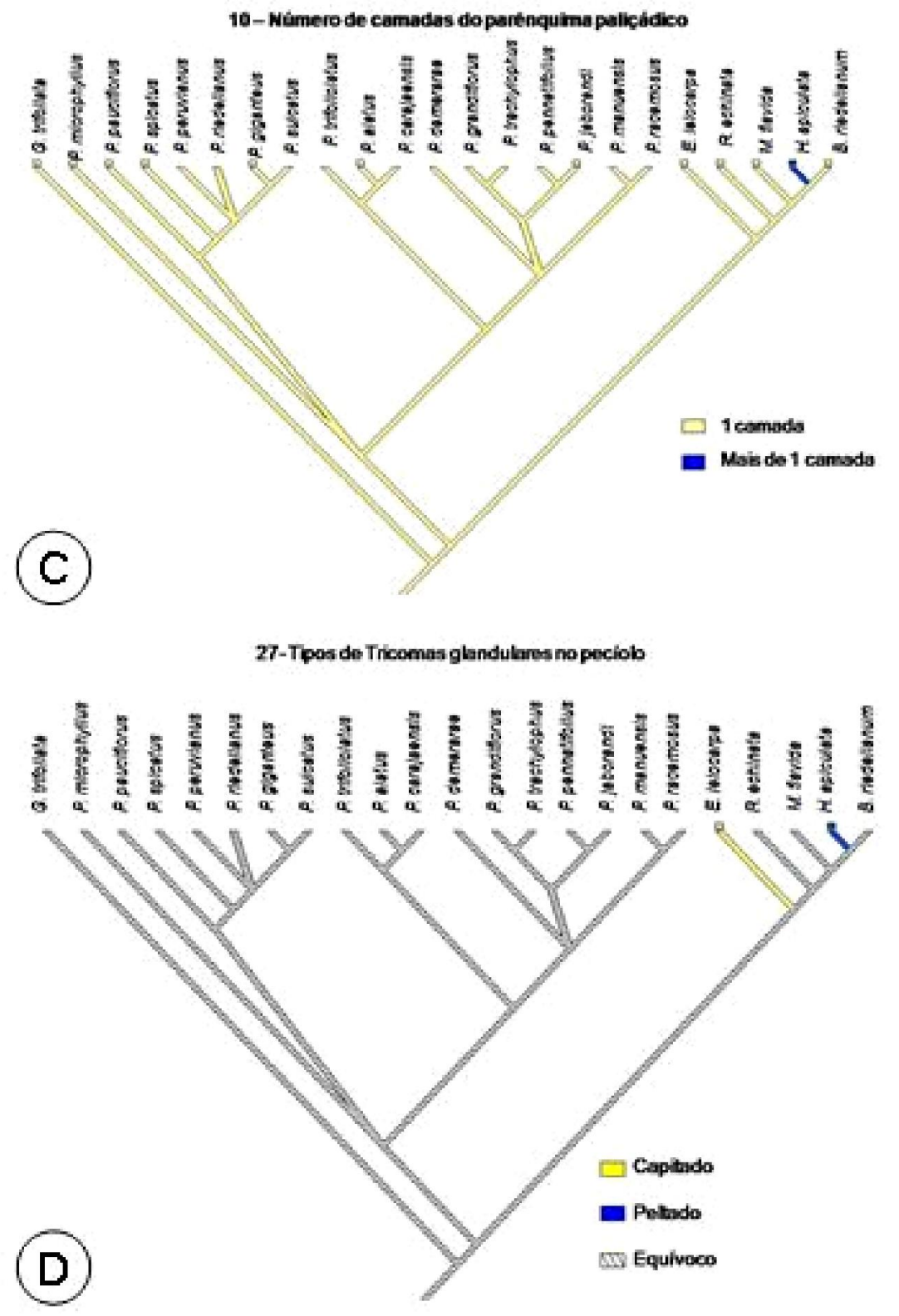

Figuras 235 C-D (contimapa). Mapeamento do caracteres $10,24,26$ e 27 . C. Húmeros de camadas de parêrquira palicadico. D. Tipos de triconas glandulares no periolo. 


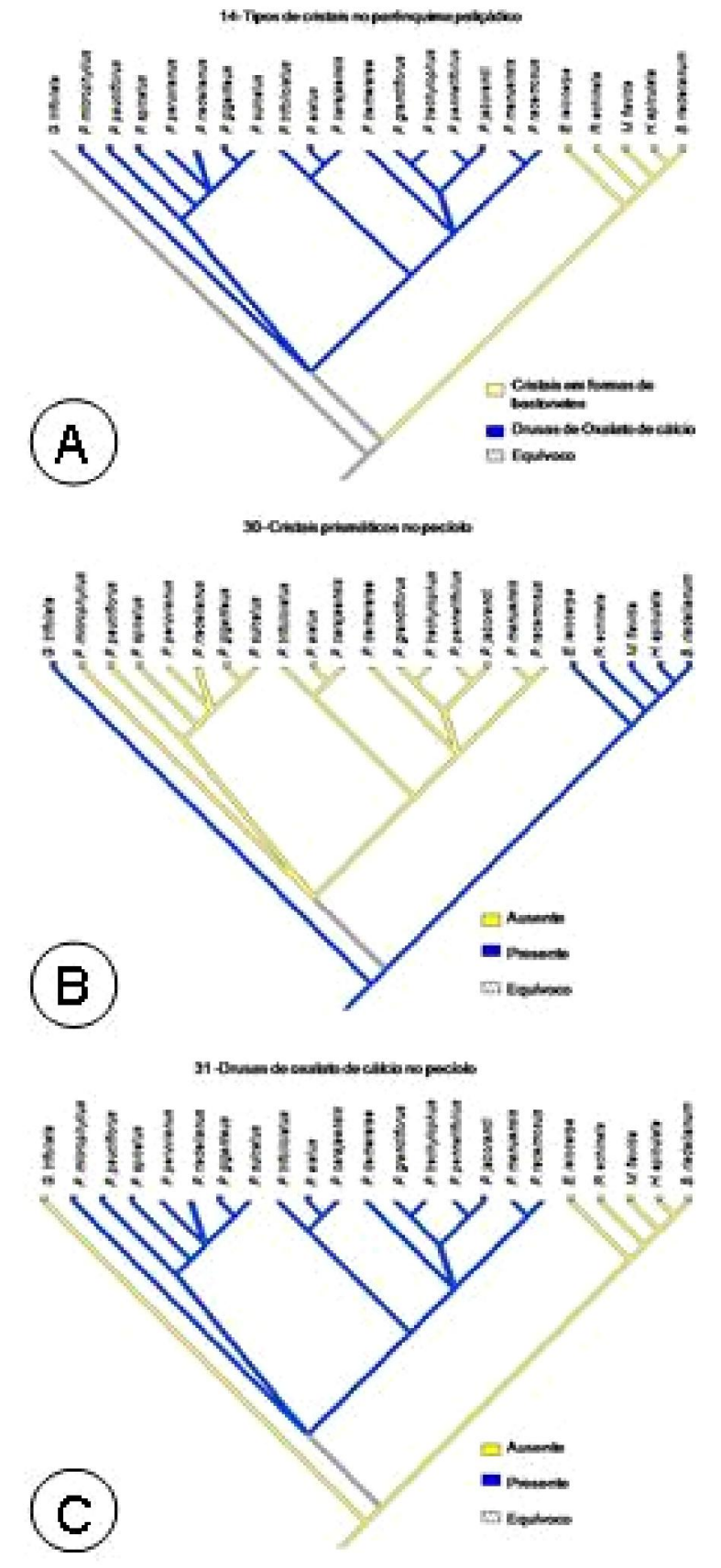

Figuras 236 A-C. Mapearmento do caracteres 14,30 e 31 . A. Tipos de cristais no parênquima palizadico. B. Cristais prismaticos no peciolo. C. Drusas de oxalato de calcio no peciolo. 


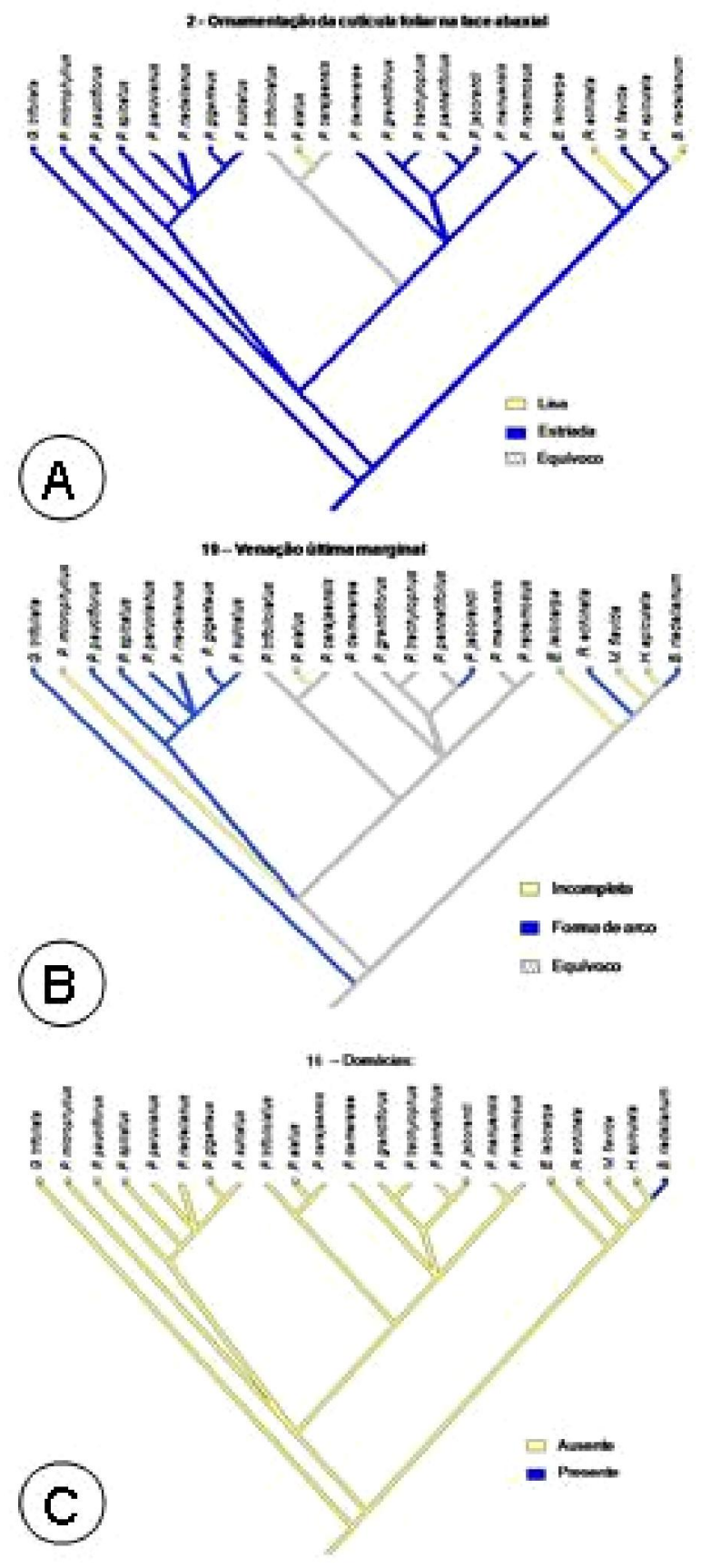

Figuras 237 A-C. Mapeamento do caracteres 2,16 e 19. A.Omamentaräo da cuticula foliar na face abaxial. B Teraça ultima marginal. C. Domácias. 


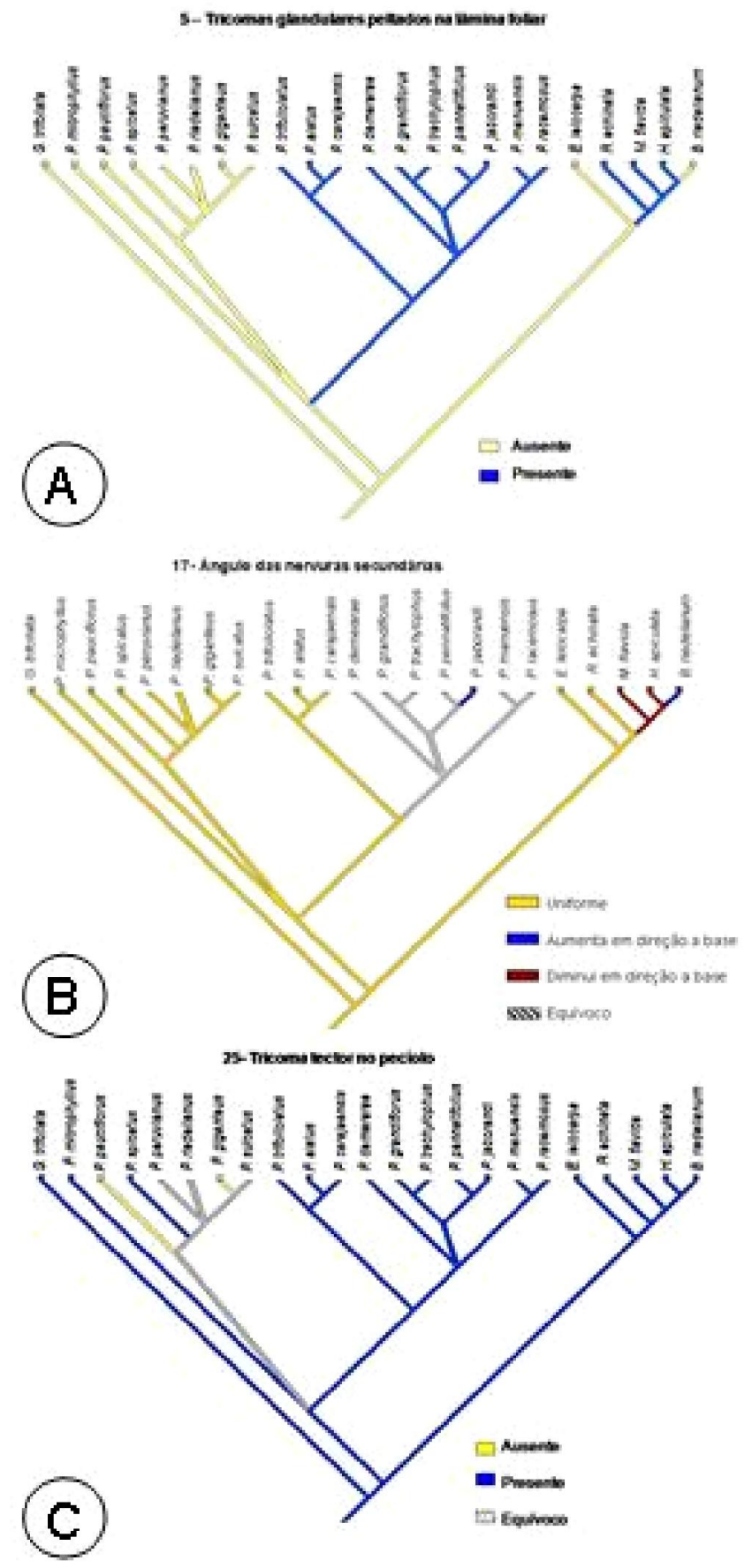

Figuras 238 A.C. Mapeamento do caracteres 5, 17 e 25. A. Tricomas glardulares peltados na läruira foliar. B. Angulo das nervuras secundárias. C. Tricomas tectores no peciolo. 